UNIVERSIDADE DE SÃO PAULO

Mariângela de Andrade Maximo Dias

A CLÍNICA DO BEBÊ PRÉ-TERMO E A ESCUTA DOS PAIS:

QUESTÕES PARA A PSICANÁLISE.

São Paulo

2008 
Mariângela de Andrade Maximo Dias

\title{
A CLÍNICA DO BEBÊ PRÉ-TERMO E A ESCUTA DOS PAIS: QUESTÕES PARA A PSICANÁLISE.
}

\author{
Tese apresentada ao Instituto de Psicologia da \\ Universidade de São Paulo para obtenção do Título \\ de Doutor em Psicologia. \\ Área de Concentração: Psicologia Clínica \\ Orientador: Prof ${ }^{\mathrm{a}} \mathrm{Dr}^{\mathrm{a}}$ Léia Priszkulnik
}

São Paulo

2008 
Dias, Mariângela de Andrade Maximo.

A clínica do bebê pré-termo e a escuta dos pais: questões para a psicanálise / Mariângela de Andrade Maximo Dias; orientadora Léia Priszkulnik. -- São Paulo, 2008.

225 p.

Tese (Doutorado - Programa de Pós-Graduação em Psicologia. Área de Concentração: Psicologia Clínica) - Instituto de Psicologia da Universidade de São Paulo.

1. Neonatologia 2. Recém-nascidos prematuros 3. Trauma do nascimento 4. Freud, Sigmund, 1856-1939 5. Lacan, Jacques, 19011981 I. Título. 


\section{FOLHA DE APROVAÇÃO}

\section{Mariângela de Andrade Maximo Dias}

A CLÍNICA DO BEBÊ PRÉ-TERMO E A ESCUTA DOS PAIS: QUESTÕES PARA A PSICANÁLISE.

Tese apresentada ao Instituto de Psicologia da Universidade de São Paulo para obtenção do título de Doutor.

Área de Concentração: Psicologia Clínica

Aprovado em:

Banca Examinadora

Prof. Dr.

Instituição: Assinatura:

Prof. Dr.

Instituição:

Assinatura:

Prof. Dr.

Instituição: Assinatura:

Prof. Dr. Instituição: Assinatura:

Prof. Dr. Instituição: Assinatura: 
DEDICATÓRIA

PARA TIAGO 


\section{AGRADECIMENTOS}

À Profa ${ }^{\mathrm{D}}{ }^{\mathrm{a}}$ Léia Priszkulnik, pela interlocução produtiva ao longo do trabalho de orientação.

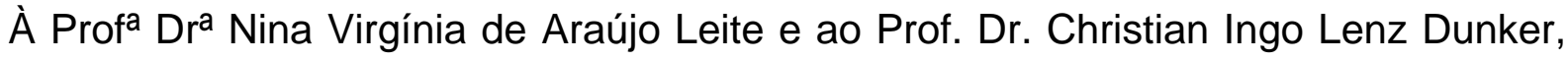
pelas valiosas sugestões no exame de qualificação.

À Equipe de Terapia Intensiva Neonatal do Hospital-Maternidade Universitário Celso Pierrô (PUCCAMP) pelo acolhimento generoso que possibilitou a realização da pesquisa nas dependências da unidade de tratamento intensivo neonatal.

Aos pais dos bebês, pelo testemunho corajoso de sua experiência durante a hospitalização de seus filhos.

À Capes, pelo apoio oferecido durante a realização deste trabalho.

Aos meus colegas do Grupo de Trabalho de Psicanálise com Crianças da Escola de Psicanálise de Campinas, pelas elaborações compartilhadas sobre as questões colocadas ao analista pela clínica psicanalítica com a criança.

À minha mãe, pelo incentivo permanente ao longo deste percurso.

À Maria Rita Salzano Moraes, pela amizade e revisão cuidadosa deste texto.

À Marli A. de Souza Alves de Oliveira, pela sua gentil colaboração na formatação do trabalho. 


\section{RESUMO}

DIAS, M.A.M. A clínica do bebê pré-termo e a escuta dos pais: questões para a psicanálise. 2008. 225 f. Tese (Doutorado) - Instituto de Psicologia, Universidade de São Paulo, São Paulo, 2008.

Este trabalho discute as vicissitudes da constituição do sujeito do desejo na clínica do bebê pré-termo, constituição agenciada pela articulação das funções materna e paterna que atualizam para um sujeito a estrutura da linguagem, isto é, que articulam o desejo à dimensão da falta. Na clínica do bebê pré-termo o investimento desejante que sustenta a aposta simbólica que preside a inscrição do infans no dizer e no desejo do Outro é posto à prova, pois os pais, primeiros representantes do Outro (simbólico) para o recém-nascido, são confrontados de maneira intempestiva com a dualidade da vida e da morte. A escuta dos pais durante a hospitalização de seus bebês numa unidade de tratamento intensivo neonatal revela que a construção do laço primordial entre pais e filhos sofre o impacto do discurso técnico-científico, pois o lugar e o saber dos pais são inicialmente deslocados pelo saber médico e sancionados como insuficientes para cuidar da criança. Os fragmentos das falas dos pais apresentados neste trabalho são analisados à luz dos ensinamentos da psicanálise. Essa análise mostra que a escuta dos pais humaniza esse nascimento, pois implica-os numa elaboração psíquica que atenua a angústia e o sentimento de desamparo que acompanha esses nascimentos, visto que o bebê pré-termo produz uma inquietante estranheza em seus pais. O apoio psíquico fornecido a eles favorece a retificação do olhar fundador em relação ao bebê, minimizando o impacto das separações precoces que ameaçam a construção dos laços de amor e de desejo entre pais e filhos, a qual sabemos ser uma prerrogativa da saúde psíquica.

Palavras-chaves: 1. Neonatologia 2. Recém-nascidos prematuros 3. Trauma do nascimento 4. Freud, Sigmund, 1856-1939 5. Lacan, Jacques, 1901-1981. 


\begin{abstract}
DIAS, M.A.M. The preterm baby clinic and the hearing of the parents: questions for psychoanalysis. 2008. $225 \mathrm{f}$. Thesis (Doctorate) - Instituto de Psicologia, Universidade de São Paulo, São Paulo, 2008.
\end{abstract}

This work discusses the vicissitudes of the constitution of the subject of the desire in the clinic of preterm babies, a constitution that is promoted by the articulation of the motherly and fatherly functions that update to a subject the structure of language, that is, that articulates the desire with the dimension of lack. In the preterm baby clinic, the desiring investment that sustains the symbolic anticipation that presides the inscription of the infans in the discourse and in the desire of the Other is challenged, since parents, the first representatives of the (symbolic) Other for the newborn, are confronted in an untimely way with the duality of life and death. The hearing of the parents during the hospitalization of their babies in an neonatal intensive-care unit reveals that the construction of the primordial bond between parents and children suffers the impact of the techno-scientific discourse, since the place and the knowledge of parents are initially displaced by the medical knowledge and sanctioned as being insufficient to take care of the child. The fragments of the testimonials of the parents presented in this work are analyzed at the light of the teachings of psychoanalysis. This analysis shows that the hearing of the parents humanizes this birth, because it involves them in a psychical elaboration that attenuates the anguish and the feeling of helplessness that follows these births, considering that the premature baby produces a disturbing strangeness in its parents. The psychic support offered to them favors the rectification of the founding gaze in relation to the baby, thus minimizing the impact of the precocious separations that threaten the construction of the bonds of love and desire between parents and children that we know as being a prerogative of the psychic health.

Key-words: 1. Neonatology 2. Preterm newborns 3. Birth trauma 4. Freud, Sigmund, 1856-1939 5. Lacan, Jacques, 1901-1981 


\section{RÉSUMÉ}

DIAS, M.A.M. La clinique du bébé prématuré et l'écoute des parents : des questions pour la psychanalyse. 2008. 225 f. Thèse (Doctorat) - Instituto de Psicologia, Universidade de São Paulo, São Paulo, 2008.

Ce travail discute les vicissitudes de la constitution du sujet du désir dans la clinique du bébé prématuré, constitution engagée par l'articulation des fonctions maternelle et paternelle qui configurent pour le sujet la structure du langage, c'est-à-dire, qui articulent le désir sous l'emprise du manque. Dans la clinique du bébé prématuré l'investissement du désir qui soutient l'enjeu symbolique qui préside à l'inscription de l'Infans dans la parole et dans le désir de l' Autre est mis à l'épreuve, car les parents, les premiers représentants de l'Autre (symbolique) pour le nouveau-né, sont confrontés de façon intempestive avec la dualité de la vie et de la mort. À travers l'écoute des parents pendant I'hospitalisation de ses bébés dans un Centre de Traitement Intensif Néonatal il s'avère que la construction du lien primordial entre les parents et les enfants subit l'impacte du discours technocientifique, car la place et le savoir des parents sont déplacés pour le savoir médical et censés être insuffisants pour s'occuper des enfants. Les fragments de la parole des parents présentés dans ce travail sont analysés à la lumière des enseignements de la psychanalyse. Cette analyse montre que l'écoute des parents humanise cette naissance, car elle les engage dans une élaboration psychique qui estompe l'angoisse et le sentiment de désaveu qui accompagnent ces naissances, étant donné que le bébé prématuré produit une inquiétante étrangeté chez les parents. Leur donner un soutien psychique favorise un autre positionnement du regard fondateur par rapport au bébé, rendant moins aigu l'impact des séparations précoces qui menacent la construction des liens de l'amour et du désir entre parents et enfants dont nous savons être la prérogative de la santé psychique.

Mots clés : 1. Néonatologie 2. Nouveaux-nés prématurés 3. Traumatismes à la naissance 4. Freud, Sigmund, 1856-1939 5. Lacan, Jacques, 1901-1981 


\section{SUMÁRIO}

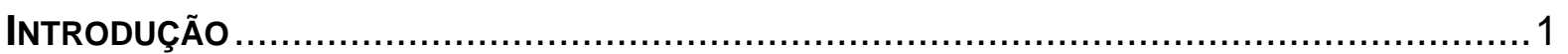

\section{Progressos da Ciência, Destinos do Sujeito}

A infância revisitada pelos trajetos da criança e da família ...........................29

Declínio da Autoridade paterna e ascensão da autoridade materna................34

Progressos da ciência e condições de humanização .................................... 43

A clínica do bebê: horizontes e promessas .............................................. 52

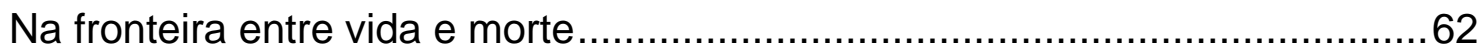

A vida é um dom que se recebe do Outro ....................................... 70

OS AVATARES DO NASCIMENTO NA CLÍNICA DO BEBÊ PRÉ-TERMO

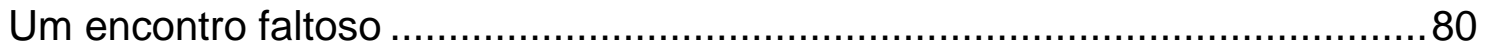

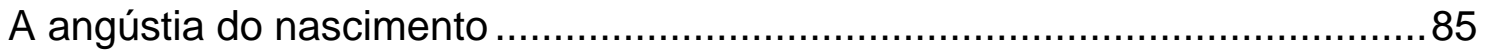

O bebê é um ser de linguagem ..................................................... 96

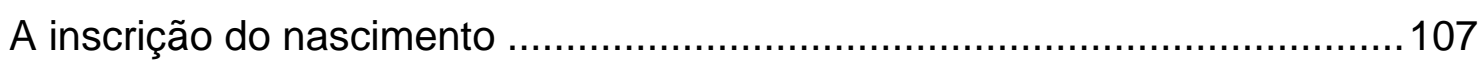

Um nascimento que não pode ser comemorado.................................111

Pediatria com Psicanálise: a aposta de Winnicott............................... 115

A angústia da mãe diante da alta do bebê ..............................................121

\section{O FEMININO, O MATERNO E A CRIANÇA}

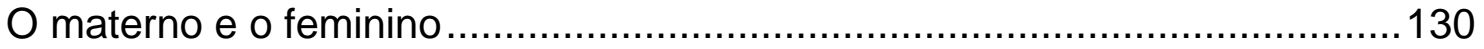

O bebê e o Outro primordial ............................................................ 137

O amor é a cicatriz do laço primordial com a mãe .................................145

O amor da mãe segundo a ótica do transitivismo ................................150

Amor materno e constituição do sujeito ........................................... 158 
Um amor terceiro ou o filho como terceiro? ........................................... 169

Vicissitudes do amor materno .......................................................... 179

Saber parental versus saber médico .................................................. 188

A presença enigmática do bebê para a mãe ........................................ 194

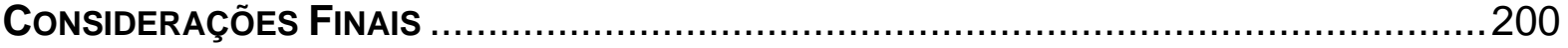

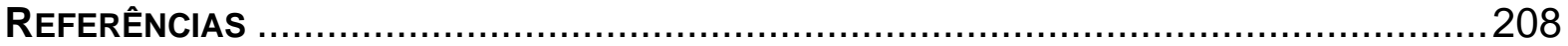

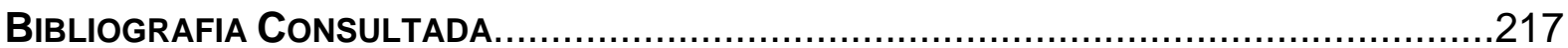

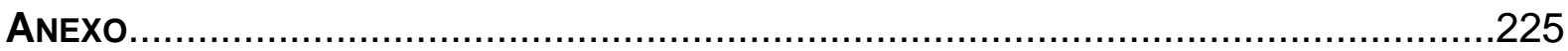




\section{INTRODUÇÃO}

A criança vem ao mundo sob certa impossibilidade de se inscrever no que a precede, daí o mal-entendido que gira em torno dela, mas também o espaço em que surge o ato de assunção subjetiva. A presença da criança ultrapassa não só o desejo de gravidez, como também o desejo de ter um filho. É compreensível que todas essas dimensões entrem em crise quando o nascimento é prematuro. Em neonatologia desaba o que, via de regra, sustenta a história. O risco de morte, a doença, a deficiência ocorrem concomitantemente ao nascimento, podendo desdobrar-se numa incerteza insuportável.

François Ansermet (2003)

Este trabalho discute as vicissitudes da constituição do sujeito do desejo na clínica do bebê pré-termo, constituição esta agenciada pelas funções materna e paterna que atualizam a estrutura da linguagem, isto é, que enlaçam o desejo à dimensão da falta, assegurando ao sujeito um lugar no desejo que o antecede. Para a psicanálise, essa estruturação demanda uma antecipação simbólica inaugural que inscreve o recém nascido no dizer e no desejo do Outro, uma vez que o desamparo que marca a chegada da cria humana ao mundo confere um estatuto de urgência aos laços de dependência com o semelhante. O recém-nascido é inicialmente prévisto e pré-dito no e pelo Outro, pois ele não se constitui sozinho. "O Outro é o lugar em que se situa a cadeia do significante que comanda tudo que vai poder presentificar-se do sujeito, é o campo desse vivo onde o sujeito tem que aparecer" (Lacan, 1979, p. 193). Em neonatologia, conforme assinala Ansermet na epígrafe acima, tudo o que via de regra sustenta a história perde seu sentido, pois os nascimentos de risco são vivenciados como um turbilhão pelos pais e colocam à prova o investimento libidinal no bebê. 
O debate, cada vez mais atual, sobre a oportunidade e a relevância da presença do psicanalista nos contextos institucionais e nos dispositivos médicos com vistas a acolher, com sua escuta, os efeitos das novas tecnologias no limite do surgimento da vida, nos instigou a refletir sobre os riscos e os desafios que essa nova realidade apresenta à subjetivação do bebê pelos pais. A clínica do bebê prétermo coloca em cena essa complexa injunção, uma vez que as tecnologias que prolongam a vida repercutem na humanização da criança pelo desejo dos pais. O bebê pré-termo é inicialmente deslocado de sua identificação ao ideal parental, já que o risco de vida que o acompanha após o nascimento posiciona-o como objeto dos cuidados intensivos, ou seja, do discurso médico. Na clínica do bebê pré-termo, os laços que sustentam um lugar para o sujeito no desejo do Outro sofrem as conseqüências de um nascimento ocorrido na urgência, pois os pais, primeiros representantes do Outro (simbólico), para o recém-nascido são confrontados com a violência desse nascimento.

Procuramos melhor situar o impacto dos nascimentos medicamente assistidos no encontro entre pais e filhos mediante a realização de uma pesquisa exploratória desenvolvida no interior de um serviço de tratamento intensivo neonatal, nas dependências de um Hospital-Maternidade Universitário. Os sujeitos da pesquisa foram os pais dos bebês pré-termo e a escuta dos pais ocorreu durante o período de hospitalização de seus filhos. A pesquisa pretendeu demarcar a repercussão dos nascimentos prematuros na construção do olhar amoroso dos pais para o seu bebê, pois o sentido tomado pela hospitalização da criança é capital nessa construção, isto é, no devir do sujeito. As elaborações que serão apresentadas ao longo deste trabalho procedem da análise do texto constituído pelas falas dos pais, e estão 
orientadas pelos pressupostos da psicanálise. Esta análise também contemplou o acompanhamento da rotina da unidade de tratamento intensivo neonatal.

As entrevistas com os pais foram efetuadas após o nascimento de seus filhos e a partir de seu prévio consentimento. Procurou-se encaminhar as entrevistas em condições que resguardassem sua privacidade e Ihes foi assegurado que sua identidade, assim como a de seu filho, seriam preservadas no presente estudo. $\mathrm{O}$ ritmo das entrevistas acompanhou a disponibilidade de sua presença no serviço hospitalar, procurando respeitar os momentos em que eles desejavam permanecer junto a seus filhos, bem como aqueles nos quais eles procuravam notícias sobre o estado geral de saúde de suas crianças junto à equipe médica.

As coordenadas teóricas que sustentaram a escuta e a leitura do texto constituído pela fala dos pais foram as da psicanálise, no marco da obra de Sigmund Freud e de Jacques Lacan. No processo de construção dessa análise foram também tomados outros autores, cuja elaboração teórica foi considerada relevante para a discussão do tema. Por tratar-se de uma pesquisa de natureza qualitativa, vale assinalar, que nesse caso, partimos da não exterioridade do pesquisador em relação ao objeto investigado, quer dizer, consideramos que o pesquisador se incluiu e se constituiu como elemento de um acontecimento que abarcou escolhas e decisões em relação ao prisma e ao contexto em que essas falas se produziram e foram lidas.

O estudo pretendeu, então, contextualizar os efeitos dos nascimentos prematuros na simbolização da criança pelos pais, já que as condições desses nascimentos produzem uma incerteza dolorosa para os pais em relação à 
expectativa de vida da criança e impõem o afastamento imediato entre pais e filhos. Essa circunstância nos levou a considerar que a função desempenhada pela equipe médica não se limitava apenas às decisões das condutas médicas e técnicas que asseguram a sobrevivência do bebê, mas também, que a posição da equipe quanto à expectativa com relação ao bebê é um fator influente na construção do vínculo afetivo entre pais e filhos. Levamos em conta, portanto, o impacto, para os pais, do diagnóstico e do prognóstico médicos em relação à criança.

Partimos da hipótese de que tais nascimentos requerem um tempo de inscrição e de elaboração do traumatismo do nascimento para os pais, de modo a que eles cheguem a decifrar esse bebê que chega ao mundo em circunstâncias tão diferentes. Em todo nascimento comparece um hiato para os pais entre o bebê real e o bebê imaginário. No entanto, nos nascimentos prematuros, essa distância é vivenciada de maneira dramática pelos pais, pois a fragilidade do bebê muitas vezes os impede de se reconhecer em seu filho. Estudos nesse campo mostram que as lacunas psíquicas infligidas ao psiquismo parental, devido aos riscos de vida iminentes que acompanham esses nascimentos, exigem uma atenção redobrada, a fim de que a criança não corra o risco de apenas existir para seus pais aderida ao traumatismo que acompanha o nascimento.

Para Ansermet (2003) o risco mais importante na clínica do bebê pré-termo é o de que os pais permaneçam embaraçados nos efeitos de sideração desses nascimentos. A dimensão do traumatismo é, nesse nascimento, uma dimensão incontornável, pois os pais são confrontados de maneira aguda com a dualidade da vida e da morte. O autor considera que, na clínica do bebê pré-termo, a experiência 
vivida pelos pais é mais próxima daquilo que Freud descreveu como neurose de susto (Schrek) ou pavor, para destacar a função do efeito de surpresa, do imprevisto, isto é, da falta de preparação para a angústia (Angst). Esta distinção será relevante para acompanhar alguns apontamentos de Lacan (2005) a respeito do fenômeno da angústia.

Estamos de acordo com Ansermet quando define o estatuto da clínica do bebê pré-termo como uma clínica do real $^{1}$, pois ela coloca em jogo, de maneira redobrada, a dimensão de um elemento que é irredutível a todo nascimento, à vida humana, a saber: a passagem do não-ser ao ser. Considerando que essa clínica está em permanente sujeição ao comparecimento do real, tomamos a necessidade da reflexão sobre as modalidades de acolhimento das angústias dos pais como fundamental para que a crise deflagrada pelo nascimento não consolide uma ameaça ao investimento libidinal parental, necessário à construção do sujeito na criança.

Vários psicanalistas e pedo-psiquiatras apontam que os dispositivos de acolhimento às crianças hospitalizadas devem zelar para que as hospitalizações não sejam uma experiência mortífera nem para elas, nem para seus pais. Mathelin (1997), por exemplo, pondera que as hospitalizações prolongadas não precisam representar um risco à constituição subjetiva da criança, desde que esta seja, entretanto, acolhida desde o início de sua jornada como um sujeito portador de uma

\footnotetext{
${ }^{1}$ Lacan define o real como um dos registros da realidade humana que se articula ao simbólico e ao imaginário. Ele designa pelo real aquilo que não cessa de não se escrever, ou seja, o que excede ao simbólico. A morte, a diferença sexual, o gozo e a mulher são alguns dos nomes do real.
} 
história, quer dizer, desde que os pais possam sustentar um lugar simbólico para a criança.

A interdisciplinaridade que abrange a clínica do bebê pré-termo coloca em cena diferentes perspectivas em relação ao estatuto dos cuidados requeridos para assegurar a sobrevivência e o bem-estar do prematuro. Nesse caso consideramos que é necessário distinguir os diferentes planos que entram em jogo nos nascimentos medicamente assistidos, pois o vir-a-ser da criança como sujeito corre o risco de se confundir com a urgência dos atos que visam à recuperação das insuficiências do organismo, ou seja, a de que os esforços para salvar o organismo negligenciem a dimensão do sujeito. Mathelin (1997), a esse respeito, aponta que o trabalho de reanimação da criança está para além da reparação de um funcionamento orgânico que se encontra deficitário. O bebê depende dos procedimentos dolorosos a que tem de ser submetido, tanto para o monitoramento assíduo de suas funções vitais como para o controle de sua instabilidade orgânica conseqüente à prematuridade clínica, porém esses procedimentos devem ser conduzidos de maneira a que não sejam ignoradas as condições simbólicas que favoreçam a estruturação da criança como sujeito. Os cuidados e a atenção para com o bebê e seus pais devem estar comprometidos com a construção e com a preservação da qualidade dos laços que asseguram a inserção do bebê num desejo que não seja anônimo. Para a psicanálise, o pivô da construção subjetiva é o desejo do Outro, pois o simbólico precede o sujeito.

Na clinica com a criança, a demanda de escuta dos fenômenos e sintomas que espelham uma desarmonia no desenvolvimento infantil nunca se restringe 
apenas às exigências do contexto familiar imediato da criança. No caso de um nascimento que requer a intervenção dos dispositivos de cuidados médicos encontramos, reunidas, várias perspectivas que, além de porem em cena as questões da filiação parental, repercutem as novas aspirações da visada do discurso técnico-científico. Concordamos com Bergés e Balbo (1997), quando apontam que, quando se trata da criança, a demanda não reflete apenas uma expectativa familiar, mas igualmente social já que, para além do gozo de seus pais, a criança é convocada a realizar o gozo do Outro social. Nessa perspectiva, o estatuto da saúde e da doença na infância é, igualmente, um elemento a ser ponderado, já que o bebê pré-termo encontra-se longe de coincidir com a criança imaginária do adulto, ou seja, com os ideais parentais e sociais. Esse ponto é de especial importância quando se trata de balizar as dificuldades de simbolização do bebê pré-termo pelos pais.

A presença de uma escuta mais rigorosa da dimensão dos fatores psíquicos em jogo na construção da parentalidade na clínica do bebê pré-termo vem sendo corroborada pelos esforços que têm pautado as decisões dos organismos governamentais em relação à necessidade de se estabelecer metas e estratégias que contemplem os efeitos das separações precoces quando a hospitalização da criança é uma medida inadiável. De acordo com a estimativa do Ministério da Saúde ${ }^{2}$, o elevado número de neonatos de baixo peso no nascimento (peso inferior a 2.500g., sem considerar a idade gestacional) foi reconhecido como um problema de saúde e responde por um alto percentual de mortalidade neonatal.

\footnotetext{
${ }^{2}$ Os dados mencionados foram recolhidos do Manual Técnico do Método Mãe-Canguru, Atenção humanizada ao recém-nascido de baixo peso que arrola as condutas que visam implementar a portaria n. 693 de 5/7/2000, a Norma de Atenção Humanizada do Recém-Nascido de Baixo Peso.
} 
Levantamentos estatísticos revelam que um terço das crianças com baixo peso e prematuras morrem antes de completar um ano. Foi verificado, por exemplo, que no Brasil, a primeira causa de mortalidade infantil são as afecções perinatais que abarcam os problemas respiratórios, a asfixia ao nascer e as infecções próprias em crianças nascidas prematuramente e de baixo peso. Essa avaliação reconheceu que a ausência de condutas adequadas em relação a esses bebês e suas famílias gera conseqüências graves ao nível médico e social. No que respeita as conseqüências médicas, foi constatado que a falta de uma capacitação apropriada dos profissionais implicados na assistência a essas crianças vem gerando uma elevação dos custos do atendimento. Em relação à família, por sua vez, foi observado um elevado grau de abandono sofrido por essas crianças e a recorrência, após a alta do bebê, da presença de maus-tratos.

Gomes (2001) assinala, que durante muito tempo, as famílias dos bebês prétermo foram excluídas do convívio com seus filhos e que tal situação começou a se modificar, lentamente, a partir da década de 60 , quando os profissionais tornaram-se cientes de que muitos problemas verificados no curso do tratamento, e após a alta do bebê, eram fruto do alheamento dos pais em relação ao processo de recuperação de seus filhos. Verificou-se que a adesão mais efetiva dos pais ao tratamento de seus filhos resultou, tanto numa elevação da taxa de sobrevivência das crianças, como na melhoria de sua qualidade de vida e integração familiar.

Para Klaus \& Kennel (1992, citado por Gomes, 2001) apesar de ter havido um progresso satisfatório de 1945 a 1960 em relação ao diagnóstico e manejo desses bebês, ainda se conservou, por longo tempo, a conduta de mantê-los em 
isolamento. O temor do aumento do risco de infecção - fator proclamado como determinante para a conservação de normas rígidas que regulam o período de permanência dos pais com suas crianças - jamais foi efetivamente comprovado como associado à entrada dos mesmos nos berçários.

A Norma de Atenção Humanizada do Recém-Nascido de Baixo Peso, regulamentada pela portaria de $n^{\circ} 693$ de 5/7/2000 pelo Ministério da Saúde declara como objetivo geral a capacitação dos profissionais na utilização do Método Canguru, priorizando uma visão interdisciplinar da saúde integral pais-bebês. A implementação de uma nova postura e de um novo olhar para as condições do nascimento, visando o atendimento humanizado ao bebê e sua família, desdobra-se em vários planos e estratégias que devem ser seguidos, a fim de que seus objetivos sejam alcançados, a saber: a habilitação profissional na humanização dos cuidados hospitalares e ambulatoriais à gestante, à puérpera e ao recém-nascido de baixo peso; o conhecimento do psiquismo específico da gestação superposto ao da puérpera, mãe de um bebê prematuro; o exame adequado das características psicofísicas do ambiente cuidador no hospital; e a promoção de condutas que incentivem a formação do vínculo pais-bebês e valorizem o aleitamento materno.

Considerando que os avanços tecnológicos para diagnóstico e manuseio de recém-nascidos enfermos, notadamente os de baixo peso, melhoraram de forma impressionante as chances de vida desse grupo etário e que o adequado desenvolvimento dessas crianças é determinado por um equilíbrio quanto ao suporte das necessidades biológicas, ambientais e familiares, cumpre estabelecer uma contínua adequação, tanto da abordagem técnica, quanto das posturas que impliquem em mudanças ambientais e comportamentais com vistas à maior humanização do atendimento (Ministério da Saúde, 2002, p. 18). 
Em linhas gerais, as condutas previstas pela portaria que regulamenta a Norma de Atenção Humanizada ao Bebê de Baixo Peso têm em vista promover, no que respeita à equipe interdisciplinar, uma nova postura que implica no reconhecimento mais amplo da condição de sujeito do bebê, daí uma série de orientações que passam a nortear as manobras desses bebês durante os procedimentos executados nas rotinas das unidades de tratamento intensivo. A presença dos pais passa a ser um vetor essencial dessa nova postura que os inclui como protagonistas do tratamento e da recuperação da criança.

A unidade de tratamento intensivo neonatal, onde foi realizada a pesquisa da rotina de cuidados aos bebês prematuros e o contato periódico com os pais, passou a priorizar condutas que se destinam ao credenciamento da instituição na categoria de Hospital Amigo da Criança. A iniciativa, Hospital Amigo da Criança, visa, além do reequipamento das unidades hospitalares, ao aperfeiçoamento da conduta técnica e à mudança na postura do profissional, de maneira a sensibilizá-lo "[...] com uma abordagem holística de seu paciente" (Ministério da Saúde, 2002, p. 11). Destacamos entre as condutas priorizadas pelo serviço: o incentivo à presença dos pais junto ao bebê (eles passam a ter livre acesso ao serviço para permanecer com seu filho a qualquer hora do dia), o fornecimento de uma orientação apropriada quanto à importância de sua participação no tratamento do bebê e o incentivo ao aleitamento materno.

O privilégio ao atendimento perinatal tem sido o foco das atenções do Ministério da Saúde, tendo em vista responder ao desafio de reduzir a taxa de mortalidade infantil, bem como implementar uma mudança de postura em relação ao 
neonato de baixo peso e pré-termo e sua família. A experiência pioneira desenvolvida na Colômbia, no início dos anos 80, pelo Dr. Rey Sanabria, método canguru, com bebês de baixo peso em uma maternidade pública de Bogotá, tem servido de inspiração a uma série de propostas para a assistência materno-infantil que tem como perspectiva desenvolver uma rede de atenção que visa a um atendimento mais humanizado aos bebês e suas famílias.

O método Mãe-Canguru, que foi implementado pela primeira vez em 1978 em Bogotá pelo Dr. Edgar Rey Sanabria, teve continuidade nos desenvolvimentos realizados em 1979 pelos doutores Héctor Martinez Gómez e Luis Navarrete Pérez, ambos pediatras do Instituto Materno-Infantil de Bogotá. A construção de uma metodologia específica que orientasse a assistência ao bebê de baixo peso e prétermo nasceu da urgência de encontrar soluções compatíveis ao nível do desenvolvimento econômico e sócio-cultural dos países em desenvolvimento que não dispõem de largos recursos para manutenção de toda a rede exigida por esse atendimento. Os cuidados intensivos exigidos pelo bebê de baixo peso e pré-termo demandam a mobilização de recursos materiais, humanos e financeiros que são onerosos. Assim, o método canguru teve como meta dois objetivos fundamentais: suprir a insuficiência de recursos materiais e evitar a separação prolongada entre a mãe e seu bebê.

Os progressos científicos alcançados a partir do século $X X$ em relação à fisiopatologia do feto, do recém-nascido prematuro e a introdução das técnicas de cuidados intensivos possibilitaram uma importante redução da taxa de mortalidade infantil, além de fornecer subsídios à compreensão das características do bebê pré- 
termo. A necessidade, contudo, de elaborar e incluir condutas que levassem em conta os aspectos psíquicos envolvidos nas separações precoces se deu posteriormente. Nesse contexto, o método canguru tornou-se uma referência para a assistência neonatal, pois além de contemplar a especificidade dos cuidados exigidos pelos bebês pré-termo e de baixo peso, suas estratégias buscaram não negligenciar a importância da preservação do vínculo afetivo entre mãe e bebê. O contato pele a pele priorizado no desenvolvimento dessa abordagem favorece a manutenção, para o recém-nascido, da continuidade de suas experiências pré e pós-natais, além de paliar os efeitos da separação precoce. Vale ainda destacar que essa abordagem favorece uma participação muito ativa da família no acompanhamento do bebê.

O canguru é, há muito tempo, um símbolo para os neonatologistas. Isto porque, por um lado, a bolsa marsupial constitui uma verdadeira incubadora viva, dentro da qual o filhote canguru permanece cinco vezes mais tempo do que no útero; por outro lado, as duas mamas proporcionam leites de composição diferente: a mama inferior produz um leite mais rico e a superior é justamente a que alimentará o animal quando ele estiver maior e suas necessidades de crescimento forem menores (Charpak, N; Calume, F.Z; Hamel, A, 1997, p. xiv).

O interesse renovado que, hoje, se volta para a criação de modalidades de acolhimento às angústias relativas ao momento do nascimento visando à humanização do parto e do nascimento, é solidário ao espírito que norteou as práticas das sociedades pré-modernas que se destinavam à simbolização dos acontecimentos decisivos da existência humana como o parto, o nascimento, a morte, a transição da infância para a puberdade, a introdução das meninas no universo dos mistérios da fecundidade quando do surgimento da primeira menstruação, etc. A literatura antropológica, sociológica e da história das religiões 
documenta que as sociedades pré-modernas são repletas de ritos de acolhimento a esses momentos de passagem. A preocupação com a criação de dispositivos de acolhimento às famílias nos diferentes domínios da assistência materno-infantil vem tentando fazer frente ao impacto do discurso técnico-científico, de modo a resgatar as condições de simbolização desses momentos de crise pelo sujeito como aqueles que se seguem a um nascimento crítico e de risco.

Eliade (2001) aponta que as cerimônias de iniciação nas sociedades primitivas e arcaicas constituem atos que simbolizam o acesso do homem a uma realização mais integral de sua condição humana junto a uma comunidade. Para as sociedades primitivas, o homem só alcança seu status humano pleno através da iniciação. Essas cerimônias incluem a tribo por completo, pois tais rituais de iniciação consistem na revelação, para o iniciado, dos mistérios religiosos que compõem o mito de origem da comunidade a que pertence. Esse mito de origem restaura a comunicação e a ligação do coletivo com o ser supremo ou a divindade à qual esse coletivo deve sua fundação. A cada rito de iniciação é toda a comunidade que se encontra regenerada, ou seja, há como que um re-nascimento que afeta a comunidade por inteiro.

[...] a repetição de um ritual estabelecido por seres divinos implica a re-atualização de um tempo original no qual se realizou pela primeira vez. Por isso um rito é eficaz, porque participa da plenitude do tempo primordial sagrado. O rito manifesta o mito (Eliade, 2001, p. 26, tradução nossa).

Os ritos que acompanham a transição da infância para a puberdade marcam uma ruptura da criança com o mundo profano do vínculo materno e franqueiam sua entrada no mundo do sagrado. Essa passagem reflete a perda da condição da inconsciência infantil com relação aos mistérios religiosos, à sexualidade, à 
fertilidade e à morte. A separação da criança e da mãe é realizada de maneira mais ou menos brutal pelas sociedades pré-modernas. Em algumas sociedades essa transição é simbolizada por uma inscrição corporal, tal como uma tatuagem, pela circuncisão, pela extração de um dente, ou ainda pela mudança do nome da criança. De acordo com Eliade (2001), os ritos de transição da infância para a puberdade sempre ecoam a experiência da morte e do re-nascimento, pois o que está em jogo é a inscrição de uma nova condição simbólica de existência do indivíduo. Trata-se da decretação da morte da infância, de aceder a uma nova forma de vida, da morte da existência profana.

Em relação à inscrição da passagem do sujeito para um novo status simbólico é digno de nota que na clínica do bebê pré-termo encontramos que tal mudança seja assinalada pelos pais através de uma mudança na nomeação de suas crianças após o nascimento ou tendo transcorrido algum tempo de sua permanência sob os cuidados intensivos. É muito freqüente, por exemplo, que seja acrescido ao nome já escolhido das meninas o nome próprio Vitória, ou então, que a escolha do nome próprio da criança sofra a influência da sugestão oferecida pelo médico que realizou o parto ou que acompanhou a gestante no pré-natal. Não é incomum por outro lado, que os pais permaneçam alguns dias embaraçados em relação à escolha do nome de sua criança. Entendemos que essa eventual hesitação em relação à nomeação da criança ou uma mudança nesse registro repercute os efeitos do impacto dos nascimentos nos pais, na medida em que o trajeto que acompanha esses nascimentos evoca uma experiência de morte e de re-nascimento. A experiência dos cuidados recebidos pelo bebê, bem como sua resposta a esses cuidados, constitui uma travessia que representa, tanto para os pais como para os bebês, como que um 
segundo nascimento ou um re-nascimento que reflete a ultrapassagem de um limite e que acena para o acesso da criança à existência simbólica.

Nessa direção Ansermet (2003) observa que os atos de reanimação do bebê pré-termo têm valor de inscrição subjetiva do traumatismo do nascimento, visto que eles constituem como que uma prova a ser transposta pela criança no percurso a ser cumprido para seu efetivo restabelecimento. O autor aponta que a criança que sobrevive a essa prova inspira em seu entorno um certo respeito, pois ela alcança um novo status humano junto ao contexto familiar, social e médico quando vem a superar os riscos de vida a que se encontra exposta devido às condições adversas que seu organismo tem de enfrentar após seu nascimento. Os diferentes momentos do percurso do tratamento pontuam o enfrentamento desses riscos pela criança. Assim, por exemplo, a saída da criança de sua dependência do auxílio dos aparelhos ou seu deslocamento da sala de cuidados intensivos para o semiintensivo marcam a ultrapassagem dos obstáculos em relação a sua implantação efetiva na vida, fatos que são comemorados pelo grupo familiar e pelo médico.

Segundo Eliade (2001) entre algumas tribos australianas a transição cumprida pela criança fica totalmente evidenciada no comportamento das mães quando suas crianças retornam ao acampamento, após terem sido instruídas nos mistérios religiosos e terem realizado as ordálias previstas pelo rito de sua comunidade. Elas choram sobre os iniciados como o fariam com relação aos mortos. A segregação temporária das crianças com relação à tribo é uma prova, cujo simbolismo remete à obscuridade que se refere tanto à experiência da morte como ao regresso ao estado fetal que preside a transição definitiva à nova condição da criança. 
Os meninos morrem para sua condição profana e ressuscitam para um mundo novo; porque, através da revelação que receberam durante sua iniciação, podem perceber o mundo como uma obra sagrada, uma criação dos deuses. [...] Esta revelação é comunicada através dos mitos de origem. Ao aprender como começaram a existir as coisas, o noviço aprende ao mesmo tempo em que ele também é a criação de outro, o resultado de tal ou qual sucesso primordial, a conseqüência de uma série de acontecimentos mitológicos; em definitivo, de uma história sagrada (Eliade, 2001, p. 43, tradução nossa).

Os mitos sobre a gestação e o parto encontram-se, por sua vez, relacionados ao simbolismo da Terra como mulher, como mãe. Vários mitos indígenas falam de um tempo remoto em que a Terra-Mãe produziu os humanos do mesmo modo que, hoje, se produzem os arbustos e os juncos. Eliade (2000) cita um mito Zuñi que conta que na origem dos tempos os "Gêmeos da Guerra" - o Céu e a Terra -, desceram através de um lago ao mundo subterrâneo. Lá embaixo encontraram um povo que não tomava alimentos sólidos, mas que se nutria somente de vapores e de odores. Esses homens ficaram horrorizados ao verem os Gêmeos se alimentarem de alimentos sólidos. Após muitas aventuras, esses homens subterrâneos foram trazidos à superfície pelos Gêmeos e é deles que descende a atual humanidade. Segundo Eliade (2000), o mito das quatro matrizes do mundo, na concepção dos Zuñi, simboliza o ato grandioso do nascimento da humanidade como uma imersão profunda na Caverna-matriz. Esse ato grandioso é recapitulado pelo processo de formação do embrião e da criança. O mito liga, desse modo, a ontogênese à filogênese.

Para o autor, no mundo primitivo, qualquer regeneração implica num regresso às origens. Assim, por exemplo, nas cerimônias destinadas à cura de um doente ou na iniciação de um candidato-xamã, são extremamente importantes a narração do mito da imersão dos homens no seio da terra e a travessia de suas diferentes fases 
em direção a superfície do solo e a luz. Os mitos de imersão no seio da terra reatualizam, em linhas gerais, a existência pré-natal. Esses mitos podem ser encontrados entre certos xamãs norte americanos. O autor descreve um breve fragmento de um desses rituais:

Um xamã Winnebago narra as peripécias de sua reencarnação: não entrará numa mulher, mas num quarto. "Lá dentro, estive consciente o tempo todo. Um dia, ouvi ruídos feitos pelas crianças lá fora, e outros ruídos também, e decidi lá ir. Então tive a impressão de que passara através de uma porta, mas na realidade, tinha de novo nascido por intermédio de uma mulher. Depois que saí, o ar fresco chocou-me e comecei a chorar" (Eliade, 2000, p. 140).

A idéia de que os humanos são gerados pela Terra é uma crença universalmente difundida e encontrada de modo inesgotável em diferentes costumes e ritos. O parto sobre o solo (a humi positio) é um ritual bastante disseminado na Austrália, China, África e América do Sul. Nos textos egípcios a expressão "sentar na terra" significa parir. O ato religioso de depositar a criança na terra aponta que a gestação e o parto são versões microcósmicas de um ato exemplar realizado pela terra. "[...] as mães humanas não fazem mais do que imitar e repetir esse ato primordial de aparição da vida no seio da terra [...]" (Eliade, 2000, p. 143). Em alguns povos o ato de depositar a criança sobre o solo é seguido pelo ato de o recémnascido ser erguido pelo pai como sinal de seu reconhecimento.

O simbolismo do regresso ao estado embrionário ou ao útero marca também inúmeros atos dos ritos de iniciação da puberdade como aqueles encontrados na tradição da antiga Índia. Eliade (2001) menciona que entre os bantúes, antes da circuncisão, os meninos são objeto de uma cerimônia chamada "nascer de novo". Nesta cerimônia, o pai sacrifica um carneiro e três dias depois envolve o menino na membrana do estômago do animal e em sua pele. Antes de ser envolvido na pele, o 
menino deve, entretanto, encostar-se em sua mãe e chorar como um bebê e permanecer por três dias envolto na pele de carneiro. O autor acrescenta que os mortos são também enterrados envolvidos em pele de carneiro e em posição embrionária.

Lévi-Strauss (1996) ao analisar o fundamento da eficácia das práticas mágicas aponta que essa eficácia se deve à conjunção de três fatores: a crença do próprio feiticeiro na potência de suas técnicas, a crença do doente de que o feiticeiro cura e a confiança da opinião coletiva que configura a cada instante como que um campo de gravitação no qual se definem e se situam as relações entre o feiticeiro e aquele que ele enfeitiça. Os procedimentos do feiticeiro estão alicerçados num sistema de representações que ordenam as diferentes fases do mal desde o diagnóstico até a cura. A adesão do coletivo a esse sistema de representações é capital, pois é da solidariedade entre a experiência íntima do xamã e do consenso coletivo que advém a satisfação intelectual e afetiva que relança a coesão do sistema de representações na qual se alicerça a eficácia simbólica que vai promover a cura do doente.

No problema da doença, que o pensamento normal não compreende, o psicopata é exortado pelo grupo a investir uma riqueza afetiva, privada por si própria de qualquer aplicação. Um equilíbrio aparece entre o que é verdadeiramente, no plano psíquico, uma oferta e uma procura; mas sob duas condições; é necessário que, por uma colaboração entre a tradição coletiva e a investigação individual se elabore e se modifique continuamente uma estrutura, isso, um sistema de oposições e de correlações que integra todos os elementos de uma situação total onde feiticeiro, doente e público, representações e processos, encontram cada qual seu o lugar (LéviStrauss, 1996, p. 210). 
Lévi-Strauss (1996) analisa a conjunção desses elementos retomando uma versão indígena de uma cura xamã realizada durante um parto difícil entre os Cuna. O antropólogo, de início, observa que se trata de uma intervenção xamanística rara, já que as mulheres indígenas dão à luz muito facilmente. O texto indígena registra um longo canto, cujo objetivo é ajudar a parturiente a enfrentar os obstáculos que obstruem o parto. A intervenção do xamã é requisitada pela parteira e o canto acompanha e narra todos detalhes que se seguem ao acontecimento: a saída da parteira ao encontro do xamã, a chegada deste ao local onde está a parturiente, a elaboração dos preparativos deste, etc. Os preparativos consistem em furmigações de favas de cacau queimadas, invocações e confecções de imagens sagradas (nuchu).

A comunidade Cuna distingue três tipos de médicos: o nele, o inatuledi e absogedi. O talento do nele, que o texto identifica com o xamã, é inato, e sua visão tem a potência de descobrir a causa da doença, isto é, o lugar do arrebatamento das forças vitais pelos maus espíritos. O nele tem, então, a força para mobilizar esses maus-espíritos e torná-los seus assistentes. Os nuchus são invocados a se encarnarem nas imagens esculpidas pelo xamã e recebem do mesmo o niga (vitalidade). Segundo a cultura indígena, o parto difícil é explicado pelos abusos de Muu (potência responsável pela formação do feto) e de suas filhas, que se apoderam do purba (alma) da mãe. O canto visa à busca do purba da mãe arrebatado por Muu e à enunciação de precauções que tentam impedir a evasão de Muu. O combate a ser realizado pelo xamã e seus assistentes (neles) ocorre na morada de Muu que, para os indígenas, significa, literalmente, a vagina e o útero da mulher grávida. 
Lévi-Strauss (1996) observa que cada parte do corpo tem seu purba (seu duplo ou alma) enquanto o nirga (força vital), corresponde no plano espiritual, à totalidade do organismo. Apenas os humanos possuem o nirga e ele se desenvolve com a idade. O nirga não pode ser roubado, apenas os purba. A vida resulta de um acordo entre os diferentes órgãos e de uma harmonia entre os diferentes purba. No parto difícil, de acordo com a mitologia indígena, o purba do útero é o responsável pela desordem patológica que perturba o desenlace do parto.

Muu não é, pois uma força essencialmente má, é uma força transviada. O parto difícil se explica como um desvio, pela "alma" do útero, de todas as outras "almas" das diferentes partes do corpo. Uma vez estas liberadas, a outra pode e deve retornar à colaboração. Sublinhemos, desde já, a precisão com que a ideologia indígena delineia o conteúdo afetivo da perturbação fisiológica, tal como pode aparecer, de maneira não formulada, à consciência da doente (Strauss,1996, p. 219).

O antropólogo aponta que o valor original do relato dessa cura xamanística reside no fato de que ela não procede nem de uma manipulação direta sobre o corpo do doente nem da administração de qualquer medicamento. Trata-se de uma intervenção que põe em causa, diretamente, a relação entre o estado patológico e sua sede. Nesse caso, o canto opera uma "manipulação psicológica do órgão doente [...]" (Strauss, 1996, p. 221).

A narrativa que acompanha todas as etapas até a cura que, nesse caso, visa à descida do recém-nascido, busca conduzir a parturiente a reviver, em todos os detalhes, o conjunto da situação, de modo a que ela integre psiquicamente, afetivamente, todos os elementos que compõem o itinerário dos obstáculos que presidiram as dificuldades do parto. O antropólogo classifica os esforços convocados 
pelo xamã em duas direções: o itinerário percorrido pela parturiente encontra-se tanto apoiado numa mitologia psico-fisiológica como numa de natureza psico-social. O xamã oferece à parturiente um mito que permite a ela integrar simbolicamente as manifestações que antes lhe eram dissonantes, ou seja, oferece uma linguagem que permite ordenar o conjunto da experiência real, de modo que se segue o desbloqueio do processo fisiológico.

A cura consistiria, pois, em tornar pensável uma situação dada inicialmente em termos afetivos, e aceitável para o espírito as dores que o corpo se recusa a tolerar. Que a mitologia do xamã não corresponda a uma realidade objetiva, não tem importância: a doente acredita nela, e ela é membro de uma sociedade que acredita. [...] O que ela não aceita são dores incoerentes e arbitrárias, que constituem um elemento estranho a seu sistema, mas que, por apelo ao mito, o xamã vai reintegrar num conjunto onde todos os elementos se apóiam mutuamente (Lévi-Strauss, 1996, p. 228).

Para Lévi-Strauss, a cura xamanística se situa a meio caminho de uma medicina orgânica e de uma terapêutica psicológica como a psicanálise. O xamã, tal como o psicanalista, suscita uma experiência que será modalizada por mecanismos que se encontram fora do controle do sujeito, ou seja, o xamã encarna o objeto da transferência da paciente, na medida em que induz a circulação das representações inconscientes que vão dar atualidade aos conflitos e resistências que vão permitir trazer à cena uma situação inicial informulada para a paciente. O xamã, porém conforme aponta o antropólogo, diferentemente do psicanalista, não apenas ouve, mas dá encarnação ao mito, quer dizer, ele vive o mito, ele se torna, pelas representações induzidas na paciente, o protagonista real do conflito, ele fala por sua doente. "[...] a parturiente indígena supera sua desordem orgânica verdadeira, identificando-se com um xamã miticamente transposto" (Lévi-Strauss, 1996, p. 230). 
O antropólogo conclui que a eficácia simbólica do método da psicanálise e daquele utilizado pelo xamã, que vai conduzir ao sucesso da cura procede do fato de que ambos mobilizam, pela re-atualização do mito, as leis estruturais que são intemporais. Nesse sentido, o autor argumenta que essas leis vão ser mobilizadas tanto no mito doado pelo xamã ao paciente como naquele que é produzido pelo paciente junto ao psicanalista, na medida em que o recurso à fala mobiliza essa estrutura simbólica que vai atualizar lugares, funções, deslocamentos, reorganização dos trajetos que vão comandar o percurso do sujeito, a partir dos efeitos da articulação do significante. O inconsciente, enquanto função simbólica, é uma função vazia, ou seja, ele é a estrutura que comanda a articulação do discurso segundo leis específicas que são as da linguagem. "[...] o mundo do simbolismo é infinitamente diverso por seu conteúdo, mas sempre limitado por suas leis. Existem muitas línguas, mas muito poucas leis fonológicas, que valem para todas as línguas" (Lévi-Strauss, 1996, p. 235). Nesse sentido, o autor ainda aponta que a forma mítica tem precedência sobre o conteúdo da narrativa.

Lacan (1995) afirma que o mito interessa à psicanálise, visto que ele constitui uma narrativa cuja estrutura é atemporal e na qual algumas constâncias não estão submetidas à invenção subjetiva. A função do mito é sempre a de articular a solução de um problema, uma urgência, isto é, a de permitir que o sujeito possa atravessar uma crise, um impasse, que o remete a dimensão do impossível que marca sua origem. Lacan ainda aponta que o molde oferecido pela categoria mítica nos reporta ao que constitui o campo de nossa experiência, pois se trata da relação do homem com a instância simbólica, daí que os temas veiculados pelos mitos conjugam numa permanência os temas que dizem respeito à vida, à morte, ao nascimento, ou seja, a 
aparição daquilo que ainda não existe ou o questionamento da relação do homem com uma força secreta caracterizada pelo que ela tem de sagrado. O mito se articula como ficção e criação.

Essa potência sagrada, diversamente designada nos relatos míticos que explicam como o homem adveio em relação a ela, deixa-se situar para nós numa identidade manifesta com o poder da significação, e muito especialmente, de seu instrumento significante. Esta é a potência que faz o homem capaz de introduzir na natureza aquilo que une o próximo e o distante como o homem e o universo, capaz também de introduzir na ordem natural, não somente suas próprias necessidades e os fatores de transformação a elas submetidas, mas a noção, que vai mais além, de uma identidade profunda, jamais apreendida minimamente entre, por um lado, 0 poder que ele tem de manejar o significante, e, por outro lado, o poder que ele tem de encarnar a instância deste significante em uma série de intervenções que não se apresentam, originalmente como atividades gratuitas, quero dizer, de realizar a pura e simples introdução do instrumento significante na cadeia das coisas naturais (Lacan, 1995, p.260).

Consideramos que a referência ao mito, no sentido da relação do homem com a função simbólica que ordena sua relação com a realidade e a verdade, nos interessa por destacar que a oferta de uma escuta dos pais possibilita a mobilização, a colocação em circulação, dos elementos significantes que constituem as coordenadas simbólicas que compõem o tecido do texto que acolhe a chegada de uma criança. Rodulfo (1990) corrobora a importância da visada do mito, argumentando que a única possibilidade de implantação na vida humana é a de que o sujeito venha a encontrar significantes aos quais possa se prender e que esses significantes se dispõem no mito familiar. Segundo o autor, quando temos como perspectiva a criança pequena ou mesmo o recém-nascido, a dimensão do lugar que a aguarda no contexto do mito familiar é de extrema importância, pois o que está em jogo são os significantes que lhe são oferecidos para que ela venha a se representar como sujeito. 
Quando dizemos "criança" em psicanálise - sobretudo quando se trata de uma criança pequena - colocamos em questão a própria questão da construção do sujeito. Tomamos [...] todo o relativo às funções nas quais se fundamenta para advir como sujeito; por exemplo, função materna, função paterna, as funções que nomeiam os implicados naquele advento, as funções que cumprem os irmãos e os membros de outra geração, como os avós (Rodulfo, 1990, p. 32).

Entendemos que a valorização da escuta dos pais no contexto dos nascimentos medicamente assistidos tem como perspectiva mobilizar a potência da palavra, de modo a que as experiências desses nascimentos possam ser integradas incluindo seus diferentes planos, a saber: a pré-história dos pais, o discurso médico, o lugar reservado à criança no contexto do mito familiar, os cuidados intensivos recebidos pelo bebê, etc. Consideramos que essa escuta é relevante, levando em conta que o advento do humano é solidário à experiência do discurso e que o nascimento é um momento de urgência. Nesse sentido, é necessário fazer o balanço da repercussão da presença das novas tecnologias no franqueamento do sujeito à existência simbólica.

Nesse percurso de trabalho vamos apresentar, no primeiro capítulo, o impacto dos avanços técnico-científicos na modalização dos laços sociais, de modo a demarcar algumas de suas conseqüências no que tange ao acolhimento da vida humana. A referência à dimensão da biopolítica desenvolvida por Foucault (1985), no vol. I de sua trilogia sobre a História da Sexualidade constituirá um importante vetor dessa análise. Essa perspectiva permitiu situar a inclusão da dimensão da vida no campo das estratégias políticas que presidiram o surgimento e o avanço do capitalismo. Essa discussão será ampliada com a contribuição da reflexão de outros filósofos e de psicanalistas que se ocuparam do exame das conseqüências do laço entre o social, a ciência, o jurídico e a família, de modo a poder demarcar as 
condições que, hoje, se apresentam à construção do humano. Nessa discussão, atentamos para os efeitos dessa nova conjunção no que concerne à inscrição da criança como sujeito.

Consideramos que, graças aos avanços técnico-científicos, há uma ampliação das expectativas de prolongamento da vida que vão incidir diretamente na reconfiguração dos limites que definem seu início e seu fim. A sobrevivência de bebês com idade gestacional cada vez menor, graças às técnicas de reanimação, é uma realidade que desafia a atenção que é requerida nesse momento, o início da vida, em que a qualidade dos laços humanos é uma prerrogativa fundamental aos alicerces da vida psíquica da criança. Estaremos, portanto, discutindo essa nova realidade, em que a humanização da criança já não se encontra exclusivamente a cargo de seus pais, e na qual o saber da ciência se revela suficientemente potente para produzir um deslizamento importante no que respeita aos fundamentos da construção do sujeito. Veremos, que o próprio sentido da vida se coloca como dependente desse deslizamento, na medida em que a determinação de seus limites se encontra sujeita à flutuação em razão dos critérios ditados pelos avanços científicos.

No segundo capítulo, apresentaremos as referências da constituição da subjetividade no marco da obra de Sigmund Freud e Jacques Lacan. Os efeitos da imersão do ser vivo na linguagem nortearão as considerações que serão realizadas em torno da questão do vir-a-ser na criança. Vamos demarcar, através da análise do texto constituído pela fala dos pais, algumas questões precipitadas pelos nascimentos prematuros. Dentre os diferentes aspectos recolhidos no curso da 
experiência dessa escuta iremos abordar a dimensão do enigma do nascimento e o da angústia do nascimento. Pretendemos situar, pela análise da fala dos pais, de que modo essa angústia se modaliza em diferentes momentos da hospitalização do bebê pré-termo, e de que modo a condição enigmática da criança os interroga. Veremos que, ora essa angústia comparece de maneira mais declarada no momento do nascimento da criança, ora sua irrupção se deflagra no momento da alta do bebê. Nos interessará contemplar a extensão da angústia produzida na mãe por esse nascimento diferente, pois tomaremos como hipótese de trabalho que a função do amor da mãe é um vetor capital na constituição do sujeito na criança. Nessa hipótese de trabalho estaremos introduzindo e dialogando com as articulações de Bergès e Balbo (2002) sobre o transitivismo e com as contribuições de Winnicott sobre a função materna. Essa hipótese de trabalho se articula à premissa já enunciada nessa introdução, a saber: a de que esses nascimentos requerem um tempo de inscrição para os pais.

No terceiro capítulo, vamos contemplar o lugar da criança nas vicissitudes do desejo feminino, pois a função materna na psicanálise é solidária a condição de haver desejo na mãe. O desdobramento da hipótese da função do amor da mãe no trajeto de constituição do sujeito na criança nos conduzirá à temática do corpo como receptáculo, desenvolvido por Bergès e Balbo. Essa noção permitirá distinguir o estatuto do corpo para a psicanálise, uma vez que se trata do corpo referido à dimensão da incidência do significante, a linguagem. Consideramos relevante destacar a distinção do corpo para a medicina e para psicanálise, uma vez que o bebê pré-termo é objeto de permanentes manobras, procedimentos e intervenções que estão alicerçadas pelo saber médico durante sua hospitalização. A esse 
respeito, Ansermet (2003) aponta como perspectiva dessa distinção que o corpo, para a medicina, é uma realidade material que ela toca em conformidade com o modelo da máquina, enquanto que, para a psicanálise, ele é uma realidade psíquica, isto é, uma dimensão que se encontra ligada à fantasia, ao desejo e ao gozo. Pommier (2008), por sua vez, afirma que a tese do corpo máquina está na contramão das experiências humanas elementares tais como o amor, o desejo, o luto, etc (informação verbal) ${ }^{3}$. Veremos que essa distinção é fundamental quando se coloca em jogo balizar a repercussão dos avanços técnico-científicos no contexto dos nascimentos medicamente assistidos.

Nessa perspectiva, assumimos que o amor materno possui um papel fundamental na humanização do recém-nascido, pois esse amor põe em obra a produção de um corpo, de uma subjetividade, a partir da inscrição dos significantes parentais enquanto ponto de partida dessa estruturação. Veremos como essa prerrogativa da função materna se articula na clínica do bebê pré-termo.

Desde a psicanálise, a humanização do sujeito depende da anterioridade do desejo do Outro, uma vez que o nascimento é um processo que opera um movimento de desaptação do biológico originário que desnaturaliza o humano (Bleichmar, 2006, p.18). O parto é um princípio, e não um fim desse processo. A criança já possui um lugar no dizer dos pais antes de vir ao mundo e, portanto, a aventura do humano implica em que o que pertence ao plano da autoconservação será subvertido, excedido, pelo investimento libidinal, desejante, que anima esse Outro que a aguarda desde antes de seu nascimento. As condições de constituição

\footnotetext{
${ }^{3}$ Conferência "A psicanálise e seu tempo" realizada por Gérard Pommier em 16 de abril de 2008 no Fórum do Campo Lacaniano - São Paulo.
} 
de um corpo são exteriores ao organismo, assim como o nome que o sujeito recebe também está fora dele.

As considerações finais buscarão reunir os elementos considerados relevantes na experiência dos pais nesses nascimentos, tendo como perspectiva estabelecer alguns marcos de intervenção na clínica do bebê pré-termo. Pretendemos indicar que esses marcos podem ser igualmente fecundos para a clínica da intervenção na primeira infância. 


\section{1 - PROGRESSOS DA CIÊNCIA, DESTINOS DO SUJEITO}

O homem ocidental aprende pouco a pouco o que é ser uma espécie viva num mundo vivo, ter um corpo, condições de existência, probabilidade de vida, saúde individual e coletiva, forças que se podem modificar, e um espaço em que se pode reparti-las de modo ótimo. Pela primeira vez na história, sem dúvida, o biológico refletese no político; o fato de viver não é mais esse sustentáculo inacessível que só emerge de tempos em tempos, no acaso da morte e de sua fatalidade; cai, em parte, no campo de controle do saber e de intervenção do poder.

Michel Foucault (1985)

\section{A INFÂNCIA REVISITADA PELOS TRAJETOS DA CRIANÇA E DA FAMÍLIA}

O modo como as prerrogativas da infância são reconhecidas e acolhidas num dado momento é determinado pelo lugar que é reservado à criança no laço familiar e social. O balizamento desse lugar implica em considerar que a estrutura da família é o lugar no qual vai ser mobilizada a produção de uma subjetividade, pois ela "[...] é, ao mesmo tempo, o veículo de transmissão dos sistemas simbólicos dominantes e a expressão em sua organização, do funcionamento de uma classe social, grupo étnico e religioso [...]" (Rosa, 2007, p. 124). A família como agente dessa transmissão encontra-se, hoje, também marcada pela ascensão do saber da ciência e pelas aspirações do capitalismo, estando desse modo o exercício da parentalidade comprometido com essa nova conjunção. Essa realidade não pode, portanto ser ignorada, quando se trata de demarcar os caminhos que se propõem ao humano para se construir a partir do encontro com o campo do Outro. A clínica do bebê prétermo, nosso tema de pesquisa, nos dará a oportunidade de discutir alguns aspectos das condições de acolhimento da vida humana, na medida em que o nascimento da 
criança se aloja, nessa clínica, manifestamente, na intersecção de diferentes práticas discursivas, pois as chances de êxito nesses nascimentos dependem dos recursos tecnológicos oriundos dos progressos alcançados pela ciência. Nesse caso, as condições de humanização pelo desejo, isto é, de produção de uma subjetividade, refletem, de maneira incontornável, uma nova configuração entre o domínio do público e do privado. Vamos começar pelo prelúdio dessa construção, de modo a acompanhar seus momentos de reviramento.

Postman (1999) afirma que uma cultura não pode ignorar sua necessidade de se reproduzir, mas pode permanecer alheia à infância como idéia social. A infância é uma invenção da Renascença que, ao lado da ciência, do Estado-nação e da liberdade de religião, surgiu como estrutura social e como condição psicológica por volta do século XVI.

O autor, no entanto, vai considerar que a sobrevivência da infância não está assegurada, pois a distância instalada entre a criança e o mundo do adulto com o surgimento da cultura letrada parece não encontrar na cultura contemporânea outros alicerces que balizem essa distância. "A leitura cria a idade adulta. Assim, num mundo letrado, ser adulto implica ter acesso a segredos culturais codificados em símbolos não naturais. Num mundo letrado, as crianças precisam transformar-se em adultos" (Postman, 1999, p. 28). O autor aponta - no fato de a história da infância ter se prestado a ser o centro de convergência de uma vasta literatura que passa a contextualizar o nascimento e os avatares da infância - um claro indício de que algo aí já anuncia seu declínio. 
No mínimo, podemos dizer que as melhores histórias de qualquer coisa são produzidas quando um acontecimento está encerrado, quando um período está em declínio, quando é improvável que uma fase nova e mais vigorosa venha a ocorrer. Os historiadores normalmente não vêm louvar e sim enterrar (Postman, 1999, p.19).

Philippe Ariès (1986) iniciou essa literatura, documentando que a representação da infância é, antes de tudo, um acontecimento solidário à reação de uma sociedade diante da expectativa de duração da vida. A preocupação com a periodização particular da vida humana vai, contudo, também refletir as aspirações sociais de uma época. Cada momento histórico elege um período da vida como símbolo de seus ideais. Assim, a importância da juventude está para o século XVII, como a infância está para o século XIX, e a adolescência para o século XX.

O autor relata em sua pesquisa que os antigos tratavam as idades da vida como categorias científicas solidárias a uma representação do mundo em que o simbolismo dos números se associava às especulações religiosas, às descrições da física, à história natural e às práticas mágicas. Não havia nenhuma correspondência entre as idades da vida e as etapas biológicas. A periodização da vida não acompanhava, tampouco, a exigência do estabelecimento da identidade que organiza a existência civil do cidadão moderno, pois essas categorias constituíam os resquícios de correspondências estabelecidas pela ciência que haviam deslizado para o campo do mito popular.

Para o homem de outrora, ao contrário, a vida era a continuidade inevitável, cíclica, [...], uma continuidade inscrita na ordem geral e abstrata das coisas, mais do que na experiência real, pois poucos homens tinham o privilégio de percorrer todas essas idades naquelas épocas de grande mortalidade (Ariès, 1986, p. 39). 
O obscurecimento da infância começou a dar sinais de seu declínio quando a morte da criança deixou de ser um acontecimento que não era mais contabilizado de maneira indiferente, levando em conta que as condições demográficas eram bastante adversas à sua sobrevivência. A cristianização dos costumes em muito contribuiu para a retirada da criança do anonimato, pois ela passou a ser concebida como um ser dotado de uma alma imortal.

A transmissão da cultura pela oralidade no Antigo Regime foi, certamente, um dos fatores determinantes pela indistinção entre crianças e adultos, pois a transmissão oral não cria nenhuma barreira a ser transposta pela criança em relação ao mundo do adulto. Postman (1999, p. 30), analisando várias fontes históricas chega à conclusão de que "[...] a criança da Idade Média tinha acesso a quase todas as formas de comportamento comuns à cultura. O menino de sete anos era um homem em todos os aspectos, exceto na capacidade de fazer amor e guerra". No mundo medieval, não se dispunha de nenhuma concepção de desenvolvimento infantil, nem pré-requisitos de aprendizagem seqüencial. A prática regular dos contratos de aprendizagem, confiando a criança a um mestre para aprender um ofício, ou enviando-a a uma outra família a fim de realizar o serviço doméstico, priorizava a transmissão do conhecimento de uma geração a outra. O privado e o público não se distinguiam, isto é, a vida familiar, profissional e social, constituía um continuum no modo de sociabilidade próprio ao Antigo Regime.

A grande revolução que vai dar início à transformação da família ocorre no século XV, quando a escola torna-se o instrumento de iniciação social que vai operar a passagem da infância para a vida adulta. A influência dos moralistas e educadores 
é decisiva nesse processo, pois eles objetavam a que a manifestação de afeição pela criança fosse pretexto para torná-la insubmissa às novas aspirações educativas e morais. "O apego à infância e à sua particularidade não se exprimia mais através da distração e da brincadeira, mas através do interesse psicológico e da preocupação moral. A criança não era divertida nem agradável" (Ariès, 1986, p. 162). Essa mudança desencadeia o surgimento de uma literatura pedagógica infantil e os manuais de civilidade, que antes se destinavam a introduzir o indivíduo nas regras e na arte da convivência em sociedade, passam, a partir desse momento, a instruir os pais quanto aos seus deveres e responsabilidades para com as crianças. Os conselhos educativos refletem a preocupação com a disciplina e com a racionalidade dos costumes e priorizam o fortalecimento da razão, do caráter e a dignidade da criança.

Ariès (1986), observa que essas mudanças não se propagaram homogeneamente entre todas as classes sociais, pois a alta nobreza e os artesãos permaneceram fiéis durante ainda longo tempo à prática de aprendizagem. Vale notar que as mudanças vão se refletir diretamente nos cuidados com a criação das crianças. O costume disseminado do envio dos bebês ao campo para aleitamento pelas amas-de-leite sofre um retraimento a partir do século XVI, quando então, as amas-de-leite são deslocadas e passam a residir com a família, a fim de que os bebês permaneçam junto de seus pais. Os progressos da higiene e da assepsia colaboraram na desaceleração dessa prática.

Observamos aqui, ao vivo, a relação entre os progressos do sentimento da infância e os progressos da higiene, entre a preocupação com a criança e a preocupação com a saúde, outra forma dos laços que uniam as atitudes da vida às atitudes diante da morte (Ariès, 1986, p. 268). 
Para medirmos o alcance das mudanças que afetam a família devemos entender que a sociedade no Antigo Regime se estruturava como uma rede de dependências. A família se inscrevia nessa rede de solidariedade, de acordo com Donzelot (1986), como:

[...] um plexus de relações de dependência indissociavelmente privadas e públicas, um elo de liames sociais, que organiza os indivíduos em torno da posse de uma situação (ao mesmo tempo profissão, privilégio e status) outorgada e reconhecida por setores sociais mais amplos. Incrustada diretamente nas relações de dependência, ela é atingida globalmente pelo sistema das obrigações, das honras, dos favores e desfavores que agitam as relações sociais (Donzelot, 1986, p. 49).

A partir do século XVII, a vida em família já não se superpõe indistintamente à vida pública, uma vez que a exigência da preservação da intimidade entre pais e filhos requer a distância em relação à presença da criadagem, dos amigos e dos clientes. A exigência de proteção à criança vai se positivar numa preocupação com a higiene e com a saúde física, introduzindo um elemento novo que é a esfera do cuidado com o corpo que goza de boa saúde. Essa preocupação vai se tornar o alvo de estratégias que implicam no estabelecimento de alianças inéditas entre a família e as estruturas sociais, econômicas, políticas, jurídicas e médicas. O novo interesse que a criança passa a polarizar está diretamente concernido ao fato de que ela condensa os ideais da cultura, ela representa o futuro, é o homem de amanhã.

\section{DECLÍNIO DA AUTORIDADE PATERNA E ASCENSÃO DA AUTORIDADE MATERNA}

A discussão sobre a criação e a conservação das crianças é o fio condutor que atravessa o século XVIII, através do questionamento dos hábitos educativos. Donzelot (1986) vai mostrar que algumas dessas práticas (a criação das crianças 
pelas amas-de-leite e uso do dispositivo da roda) tornam-se condenáveis por não corresponder às novas aspirações da sociedade industrial. A priorização do controle do desperdício das forças produtivas pelas estratégias econômicas e políticas do Estado leva à busca da identificação dos fatores responsáveis pelo empobrecimento da nação e pelo enfraquecimento da elite. O autor vai considerar, no exame dessa questão, o importante alcance da instrumentalização da vida pelo saber e pelo poder no campo das técnicas políticas. Essa reflexão dialoga com a perspectiva da biopolítica introduzida por Foucault no vol. I da trilogia da História da Sexualidade.

Foucault (1985) postula que, no século XVIII, as técnicas de poder tomam como alvo os fenômenos de população devido à sua importância no âmbito político e econômico, pois o que estava em jogo era a manutenção do equilíbrio entre as forças produtivas e as fontes de riqueza. Esse interesse é solidário, segundo o autor, com a entrada da vida na história de um modo antes ignorado. A ampliação dos domínios do conhecimento e das técnicas que possibilitam a sobrevivência do homem é concomitante com a prospecção regular das flutuações dos fenômenos da população, tais como as variações da taxa de natalidade, de morbidade, de esperança de vida, de fecundidade, do estado de saúde, de incidência das doenças, o problema da migração, etc. Para o autor, o bio-poder foi o elemento indispensável ao desenvolvimento do capitalismo, que permitiu a inserção controlada dos corpos no aparelho de produção e o ajustamento dos fenômenos de população aos processos econômicos. Nesse contexto, é a própria dimensão do homem, como ser vivente, ao nível de seu corpo e de sua existência biológica, que passará a interessar e a integrar o cálculo da direção das estratégias políticas e econômicas. 
[...] se o desenvolvimento dos grandes aparelhos de estado, como instituições de poder, garantiu a manutenção das relações de produção, os rudimentos de anátomo e de bio-política, inventados no século XVIII como técnicas de poder presente em todos os níveis do corpo social e utilizado por instituições bem diversas (a família, o Exercito, a escola, a polícia, a medicina individual ou a administração das coletividades), agiu no nível dos processos econômicos, do seu desenrolar, das forças que estão em ação em tais processos e os sustentam [...] (Foucault, 1985, p.133).

Donzelot (1986) considera que esse elemento novo, a instrumentalização da condição do homem como ser vivente, encontra-se inteiramente comprometida com a intervenção do Estado nos hábitos educativos. A análise das diferentes estratégias utilizadas para solucionar os problemas específicos das camadas populares e aqueles que afetam a burguesia vai refletir o modo como as resistências aos novos interesses da sociedade industrial são contornadas. Vale notar que a elaboração dessas estratégias vai também convergir na promoção de um equilíbrio totalmente novo da família, na medida em que o prestígio concedido à autoridade materna é um ponto de engate importante nas estratégias que visam à gestão do desperdício das forças produtivas. O debate sobre os hábitos educativos e os modos de criação das crianças põe em cena as práticas que envolvem a disciplina do corpo. No contexto dessa discussão, o sexo desponta, como argumenta Foucault (1985), como ponto de confluência das técnicas políticas, pois ele se inscreve tanto na esfera da disciplina do corpo como na regulação da população. Nessa perspectiva, o sexo da criança e o corpo da mulher constituem um dos tantos focos do saber-poder.

O questionamento da prática dos hospícios de menores coloca na ordem do dia o problema da competência e da confiabilidade das nutrizes, encarregadas dos cuidados das crianças, devido ao elevado índice de co-relação entre essa prática e a mortalidade infantil. Enquanto as mulheres burguesas podiam recrutar as nutrizes 
mais próximas de seu domicílio, as famílias carentes, por sua vez, necessitavam procurá-las mais longe. A escassez do contato entre os pais e as nutrizes punha essa prática sob a suspeita de ser um modo velado de abandono. A esse problema aliava-se, ainda, a remuneração irregular das nutrizes pelas famílias contratantes, o que as obrigava, por outro lado, a se ocupar simultaneamente de um número elevado de crianças, acarretando, com isso, uma elevação considerável da mortalidade infantil. A principal condenação a essa prática veio da medicina, que atribuía a presença da tara na infância ao excesso de intimidade e às condutas opressivas praticadas pelos serviçais com as crianças e com os jovens. O hábito do enfaixamento de bebês era considerado uma prática de risco ao desenvolvimento sadio do corpo, enquanto que o emprego da cinta entre as adolescentes era considerado uma medida que incentivava o uso perdulário do corpo.

A aliança estabelecida entre a medicina e o social vai conjugar a produção da riqueza e o tratamento do corpo. A reorganização dos comportamentos educativos direcionados às classes burguesas terá como estratégia a difusão da medicina doméstica, através da transmissão de conhecimentos que possibilitem às famílias extrair seus filhos da influência promíscua da criadagem. Nesse caso, a aliança entre o médico e a família se exercerá na valorização da autoridade da mãe, a quem caberá o encargo de resguardar a família das influências que ameaçam o grupo familiar. A literatura médica dos séculos XVIII e XIX multiplica os focos de atenção à criança, mas todos esses focos convergem para um ponto estratégico, a saber: "[...] liberar ao máximo a criança de todas as constrições, de tudo que entrave sua liberdade de movimentos, o exercício do corpo, de modo a facilitar o mais possível o crescimento de suas forças [...]" (Donzelot, 1986, p.24). A aliança entre o médico e a 
mãe desabilita a medicina popular das comadres e concede à mulher burguesa, através da valorização social de sua função de mãe, um novo poder que vem concorrer com a autoridade paterna.

Nas famílias populares, a intervenção, por outro lado, vai priorizar o estabelecimento de uma vigilância direta, de maneira a constranger liberdades assumidas, visando, com isto, reverter o quadro de abandono de menores e a regulamentação das uniões livres. O combate a esses problemas, pela assistência pública, se realiza, inicialmente, através de práticas de recolhimento e segregação (criação de hospícios de menores, dispositivo da roda, conventos de preservação, casas de tolerância, etc.) que têm como objetivo a gestão dos restos indesejáveis das famílias, a saber: os filhos ilegítimos, os membros rebeldes e as moças de má reputação. No entanto, essa tentativa de reorganizar a família popular em função dos imperativos econômicos e sociais fracassa, pois ela não desacelera o abandono das crianças, nem tampouco promove um recuo na ocorrência das alianças indesejáveis. A utilização fraudulenta do dispositivo da roda, que sempre dividiu opiniões, vai ser abolida, já que se constata que um número elevado de filhos legítimos era abandonado e depois resgatado por suas próprias mães, que se apresentavam como postulantes à função de nutrizes, a fim de se beneficiarem do pagamento pela função. A prática da exposição de crianças na roda foi desacelerada com a assistência domiciliar à mãe, e depois com a instituição do salário-família. A mãe de família popular se constituiu, então, historicamente, de acordo com o modelo da nutriz mandatada pelo Estado, caracterizada pela remuneração coletiva e pela vigilância médico-estatal. 
Para Donzelot (1986), a lógica que comanda o conflito entre o desperdício das forças produtivas, as uniões ilegais e os seus restos indesejáveis só nos é inteligível à luz dos princípios que regiam o antigo sistema de alianças e parentescos, pois a defasagem entre o sexual e as regras de aliança era produtora de ilegalidade e causa de desperdício de forças úteis.

Foucault (1985) vai situar esse problema, apontando que a divergência e o conflito entre o dispositivo da sexualidade e o dispositivo da aliança não são alheios ao próprio jogo de forças que incita e constrange o sexo pelo discurso. O autor assinala que o dispositivo da aliança visa à homeostase do corpo social, através da observância estrita das regras de parentesco que possibilitam a transmissão dos bens e a circulação da riqueza, coagindo, em contrapartida, a sexualidade não conforme aos fins da reprodução. O dispositivo da sexualidade, por sua vez, recobre o vasto campo das manifestações sexuais periféricas não constrangidas pelos limites da reprodução. O autor entende que o dispositivo da aliança garantiu ao capitalismo, num primeiro momento, a formação sem desperdício das forças de trabalho. A segunda fase do sistema capitalista vai buscar, entretanto, um outro tipo de domínio, ou seja, um domínio que já não visa mais o constrangimento da sexualidade à finalidade de reprodução, mas "[...] sua canalização múltipla dentro dos circuitos controlados da economia [...]" (Foucault, 1985, p. 107). O corpo se liga a esses circuitos enquanto um corpo que produz e consome.

O autor conclui que a família vai ser, então, o lugar em que esses dispositivos vão se entrecruzar, pois enquanto estrutura social, econômica e política de aliança, ela não exclui a sexualidade em suas modalidades não conformes aos fins de 
reprodução. Desse modo, ela "[...] é o permutador da sexualidade com a aliança: transporta a lei e a dimensão do jurídico para o dispositivo de sexualidade; e a economia do prazer e a intensidade das sensações para o regime da aliança" (Foucault, 1985, p. 103).

Vemos, então, que o incentivo à regulação das uniões livres nas classes populares vai proceder também da mesma origem, a saber: da preocupação com os excessos de encargo da assistência, quer dizer, com o ônus causado pelo controle ineficaz das forças produtivas. O alvo da estratégia, nesse caso, será a valorização do trabalho doméstico que substituirá o capital, o dote, do qual a mulher da classe popular estava privada. Essa solução vai permitir introduzir, na vida operária, uma regularidade relativa aos hábitos de higiene, alimentação e cuidados com as crianças, assim como o controle do homem pela mulher. A absorção e exploração das mulheres no processo industrial, por outro lado, vai ameaçar a estabilidade da família, já que a ampla absorção das mulheres, devido à sua remuneração mais baixa, acabou por produzir o desemprego do homem. As mulheres das classes populares que buscavam preservar sua capacidade contratual pelo dote e escapar da prostituição ingressavam nos ateliês religiosos ou nos conventos industriais. (Donzelot, 1986).

As transformações e crises da família estão ligadas à condição de que ela é uma instância, cuja heterogeneidade é funcionalizada pela flutuação das normas sociais, pelos imperativos econômicos e políticos. A transformação do equilíbrio na família, a partir da valorização das prerrogativas da função da mãe junto à criança, através da aliança da família com as instâncias jurídicas, médicas e pedagógicas é 
solidária a um processo que reflete o declínio da imago social paterna. Julien (2000) circunscreve esse fenômeno como sendo conseqüência de um novo ordenamento entre o privado e o público que vai coroar a disjunção entre a conjugalidade e a parentalidade. A passagem da vida em comunidade para a sociedade moderna caracteriza-se pelo nascimento de uma clivagem que produz a convergência do privado com o lugar da conjugalidade e do público com o da parentalidade. Acompanhamos, pela análise das estratégias de intervenção do estado na família burguesa e popular, como o domínio da parentalidade se abre à presença do terceiro social, intervindo na relação entre pais e filhos. A humanização da criança não pertence mais ao domínio restrito dos pais.

No século XIX, professa-se que o bem estar familiar depende da maravilha deste ninho que constituem o corpo e o coração da mãe. [...] O século XX pensa, antes, que essa relação não pode ser deixada ao arbítrio da mãe, nem do pai. Em nome do bem do filho, vem então tomar lugar, sob diversas figuras, um terceiro social: o professor, a pediatra, a psicóloga, a assistente social, o juiz de menores, o juiz de varas de família (Julien, 2000, p.15).

Julien (2000) assinala que nas sociedades tradicionais o domínio do lar, oika, da família, tinha como função a reprodução, a subsistência e a perpetuação da vida. A esfera da cidade, da Polis, possuía a primazia da ordem da lei que fundava as trocas pela fala. Era a tradição cultural particular que realizava o liame entre esses dois domínios, de modo tal, que os grandes acontecimentos como o nascimento de um filho, o casamento e a morte de um pai, podiam ser comemorados e compartilhados, isto é, o próprio e o comum podiam se encontrar. O autor argumenta que, a passagem da comunidade para a sociedade, produziu um outro sentido para a dimensão do público que é bem contemplada pelos dois termos alemães, Publikum (um determinado grupo) e Öffentlich (um público qualquer, um qualquer 
anônimo). Nessa passagem, há dissolução do poder do pai que, antes apoiado pela comunidade, sustentava hierarquicamente as relações dentro da família. Os laços conjugais estavam, então, atados à fidelidade aos valores da linhagem a ser perpetuada. "[...] a lei da proibição do incesto, que é editada pela cidade, realiza-se efetivamente pela autoridade do pater famílias, ao qual a cidade reconhece este poder" (Julien, 2000, p.11). Um dos claros sinais desse declínio é o fato de que os laços conjugais passam a ser consolidados pelo consentimento mútuo entre um homem e uma mulher, e não em função da preservação do patrimônio familiar. O próprio sentido do privado também se modifica, pois ele ganha o estatuto de uma positividade. O autor formula esse deslizamento entre o privado e o público, entre a conjugalidade e a parentalidade na seguinte equação: Intimidade conjugal, extimidade parental.

Nesse contexto, o nascimento de uma criança polariza as reviravoltas que não cessam de ocorrer nas fronteiras entre o privado e o público, na medida em que a relação de filiação ultrapassa o domínio do conjugal. Os pais já não são os interlocutores privilegiados de seu filho. A legião de especialistas (educadores, psicólogos, médicos, etc.) que passam a se interpor na relação da criança com seus pais só é pensável a partir do momento em que está realizada a disjunção entre a conjugalidade e a parentalidade. A função operante do terceiro significativo entre a mãe e a criança não é mais uma prerrogativa do pai.

Lebrun (2004) afirma que o avanço da ciência positivou decisivamente esse deslocamento, ameaçando o encontro do sujeito com a disparidade originária que atualiza a diferença entre o Outro e o UM. O que está em jogo, então, nesse 
processo é a validação, ou não, pelo social, de um lugar terceiro, a partir do qual se organiza simbolicamente o mundo humano. A positivação, no social, dos enunciados da ciência vai, por sua vez, perturbar a transmissão dos significantes da filiação e da sexualidade que asseguram a inscrição de um lugar particular para o sujeito no mundo, visto que o agenciamento do sujeito predominantemente pelo saber da ciência o priva do laço significativo com um Outro marcado pelo pacto simbólico. A esse respeito, nos reportamos a um dos aspectos destacados por Rosa (2007), em

sua análise das novas configurações da parentalidade na contemporaneidade, quando alega que o declínio do nome do pai, em detrimento dos discursos jurídicos, científicos e pedagógicos, é, sem dúvida, um dos fatores que perturbam a inscrição do sujeito numa filiação simbólica que o autoriza a uma relação com a verdade do desejo (Rosa, 2007).

\section{Progressos dA CIÊNCIA E CONDIÇõES dE HUMANIZAÇÃo}

As condições de acolhimento à vida humana, hoje, não podem, então, ser dissociadas dos efeitos da presença da ciência na configuração dos laços sociais, pois ela intervém nos modos de subjetivação que são oferecidos ao sujeito, principalmente projetando soluções para o mal-estar do homem. Freud (1930/1974) considerou que a dimensão do mal-estar - sinônimo da presença do conflito na vida psíquica - é inerente à condição do homem como ser de desejo, na medida em que a entrada da cria humana no campo da cultura é solidária a uma renúncia original que a implica no assentimento ao interdito do incesto, quer dizer, a Lei do pai. O desejo está, pois, votado à sua perene insatisfação, já que há um impossível irremediável para o ser humano ao não poder dispor de um objeto que, 
definitivamente, possa garantir sua satisfação. Freud, a partir disso, apontou que não há, no nível do micro nem do macrocosmo, nenhum bem que possa garantir ao sujeito a felicidade, quer dizer, curá-lo de sua falta-a-ser.

Lacan (1998) reconheceu nas reflexões freudianas sobre o mal-estar na cultura os alicerces da ética da psicanálise. Para o psicanalista francês, Freud inovou no campo da ética, deslocando o eixo dessa reflexão e priorizando a presença do conflito na raiz da vida psíquica. Assim, a ética da psicanálise está menos comprometida com a dimensão do ideal, do que com o reconhecimento do real que se interpõe na busca do homem na realização do bem, seja o do seu como o do outro. Todo sujeito quer a felicidade, mas essa demanda é acolhida pelo psicanalista em sua práxis de maneira original e advertida, pois "constituir-se como o que garante de que o sujeito possa de qualquer maneira encontrar seu bem, mesmo na análise, é uma espécie de trapaça" (Lacan, 1988, p. 364). Esta é a posição da ética da psicanálise frente à condição do impossível que constitui o humano - não há Bem Supremo. Entretanto, a dimensão desse impossível encontra, hoje, cada vez mais, uma verdadeira barreira para ganhar a cena no mundo. O discurso da ciência, aliado aos imperativos do capitalismo e à lógica do mercado de consumo, age na contramão desse limite estruturante para o ser humano com a promessa de soluções e de objetos cada vez mais potentes para arrolhar a falta do sujeito. A ampliação do limite do possível se embaraça, todo o tempo, com a eliminação do impossível. Quem ganha e quem perde nesse jogo?

Vários psicanalistas, filósofos e educadores têm refletido sobre essa conjuntura, pois todos concordam que ela repercute na gestão das novas formas de 
parentalidade, nos laços conjugais, nas práticas educativas, nas práticas médicas ligadas aos problemas da fecundidade e dos nascimentos assistidos, assim como no surgimento de novos sofrimentos psíquicos e novos sintomas. O filósofo Dufour (2005) faz um balanço das conseqüências da conjunção dos progressos científicos com a nova modalidade do capitalismo, o neoliberalismo, e conclui que a demissão da capacidade de pensar e de julgar do sujeito é seu desdobramento mais relevante na atualidade. Nessa linha de argumentação, o autor considera que a mutação do capitalismo foi tramada com a globalização da economia e com a imposição da lógica do mercado de consumo. Da mesma forma, estima que as mudanças deflagradas representam uma morte programada do sujeito que vem dando claros sinais nos últimos vinte anos.

A tese central do filósofo é a de que o triunfo do neoliberalismo é solidário da destituição radical de um terceiro significativo, desde onde o ser falante constitui sua humanidade. Nesse sentido, é a própria condição humana que se encontra em risco, na medida em que a dimensão da transcendência que ordena as trocas entre os homens é desalojada pelo imperativo da livre circulação e expansão da mercadoria.

\footnotetext{
Hoje, os homens são solicitados a se livrar de todas as sobrecargas simbólicas que garantiriam suas trocas. O valor simbólico é assim desmantelado, em proveito do simples e neutro valor monetário da mercadoria, de tal forma que nada mais, nenhuma outra consideração (moral, tradicional, transcendente, transcendental...) possa entravar sua livre circulação. Daí resulta uma dessimbolização do mundo. Os homens não devem mais entrar em acordo com os valores transcendentes, simplesmente devem se dobrar ao jogo da circulação infinita e expandida da mercadoria (Dufour, 2005, p. 13).
}

Dufour (2005) assinala que os sinais da fratura da modernidade estão por toda parte e cita alguns de seus sinais: O fenômeno da dissolução das grandes 
ideologias e das grandes narrativas (políticas e religiosas), a ascensão do individualismo, as interrogações múltiplas sobre a identidade sexual, a desinstitucionalização da família, o reinado do dinheiro, a massificação nos modos de vida, o domínio das tecnologias que permitem, por exemplo, a ampliação da duração da vida, a diminuição do papel do Estado, a publicização do espaço privado, etc. O filósofo ainda pondera que os efeitos da instantaneidade da informação e da imediatez que se seguem ao cortejo dos avanços tecnológicos são responsáveis pela nova configuração do ambiente simbólico em que se desenrola a construção do humano.

A destituição dos valores simbólicos que ordenam as trocas humanas se faz acompanhar de uma nova disposição do sujeito aos fluxos da expansão da mercadoria. O sujeito se conta a partir dos produtos que ele pode consumir e exibir, e menos a partir de suas coordenadas históricas. A ideologia neoliberal, segundo o autor, oferece um novo estatuto de objeto, a mercadoria, que passa a ser promovida como único real para o sujeito. O amálgama entre o objeto de consumo e o objeto de desejo conduz à elisão da divisão subjetiva e, conseqüentemente, ao empobrecimento dos recursos criativos e inventivos do ser humano frente ao cumprimento de seu destino como ser de desejo. "A decepção causada pelo recebimento do objeto é a mais segura mola propulsora do poder da narrativa da mercadoria" (Dufour, 2005, p.77).

Dufour (2005) argumenta que, hoje, o sujeito está sozinho, tendo que se encarregar dos meios de se subjetivar e, ao mesmo tempo, sem poder fazê-lo, pois nos encontramos num momento em que há a dissolução do Outro, no sentido do 
Outro simbólico. O poder da narrativa da mercadoria se imiscui na economia pulsional e suborna o sujeito com a oferta de objetos, sempre mais sedutores, que irão premiá-lo com a garantia da felicidade: a cada desejo, seu objeto. No entanto, a imposição da narrativa do mercado determina a própria destruição do tecido social e cultural, já que a velocidade do fluxo de capitais e da mercadoria impõe um remodelamento incessante do conjunto da sociedade.

Notemos, seguindo a reflexão do filósofo, que a condição de solidão do sujeito é acompanhada, contudo, de uma exigência de que ele se torne autônomo. A conquista legítima da autonomia e da emancipação, porém, fica ameaçada, na medida em que falta o suporte simbólico que a possibilita. Dufour (2005) chama a atenção para o fato de que essa aventura é obra de uma vida que não dispensa o sujeito de ter, antes, que passar pelo Outro enquanto referência a um lugar terceiro, a partir do qual ele pode endereçar e enganchar uma demanda.

O Outro é a instância pela qual se estabelece para o sujeito uma anterioridade fundadora, a partir da qual uma ordem temporal se torna possível: é também um "lá", uma exterioridade, graças à qual pode se fundar um "aqui", uma interioridade. Para que eu esteja aqui, é preciso, em suma, que o Outro esteja lá. Sem esse desvio pelo Outro, eu não me encontro, não tenho acesso à função simbólica, não chego a construir uma espacialidade e uma temporalidade possíveis (Dufour, 2005, p. 38).

No contexto dessa reviravolta impulsionada pelo avanço técnico-científico, Postman (1999) vai, por sua vez, constatar, com apreensão, que a re-configuração do ambiente comunicacional vai repercutir diretamente na dissolução das fronteiras entre a infância e o mundo adulto. O autor argumenta, que a potência da instantaneidade e o anonimato da informação liquidam a base da hierarquia da informação e dispensam a distinção prévia entre crianças e adultos. A mídia 
televisiva é, em sua análise, um bom exemplo para examinar esse fenômeno, pois ela escancara tudo e todos, tendo em vista que não dispõe dos meios de fazer agir o obstáculo, o segredo. "[...] é uma tecnologia com entrada franca, para a qual não há restrições físicas, econômicas, cognitivas ou imaginativas" (Postman, 1999, p.98).

A separação realizada pela cultura livresca entre o universo da criança e o mundo do adulto é, de acordo com a análise do autor, violentamente solapada pelas novas modalidades de circulação da informação. Voltando a comentar sobre a mídia televisiva, o autor assinala que ela não demanda de seu expectador a complexidade das habilidades do raciocínio lógico requerido pela cultura letrada, pois o fluxo de imagens torna irrelevante a mobilização dessas habilidades. 0 impacto produzido pela avalanche de imagens não é, contudo, indiferente ao modo como a criança vai viver as experiências que lhe são apresentadas. Postman (1999) argumenta que a ruptura dos limites entre o privado e o público intervém no cálculo do espanto, na medida em que a criança é introduzida de maneira intempestiva nos grandes temas da vida: a morte, a doença, a violência, o sexo. O autor alega que não é a mesma coisa uma criança poder ouvir pela voz de sua mãe o relato de um conto de fadas que toca nos grandes temas da existência humana, e ela ter acesso a esses temas através de imagens desacompanhadas de uma narrativa que a situem em relação ao que ela ouve e vê. É mais fecundo, simbolicamente, quando uma criança pode se enganchar nessas questões com suas próprias perguntas.

O autor é contundente em suas conclusões, ao declarar que a dissolução do limite entre a infância e o mundo adulto é uma realidade recolhida nas 
manifestações que atestam a fusão entre os gostos, as vestimentas e o uso da linguagem compartilhados sem distinção entre crianças e adultos. A exploração da imagem da criança, tanto pelo ângulo do erotismo, como pelo lado do consumo desenfreado, é um claro signo de que ela é admitida, sem nenhum tipo de proteção, em todos os segmentos da vida do adulto. Tal mudança não é alheia ao modo como um adulto, hoje, se apresenta e é apresentado nos mais diferentes contextos do cotidiano familiar e social. Ele aparece como aquele que não leva a sério o trabalho, que não se encarrega do cuidado com as crianças, que não tem opção política e não tem projetos. Vemos que, para o autor, há uma relação intrínseca entre a mudança no olhar para a criança e o que se passa do lado do adulto (Postman, 1999).

Essa relação permite entender que o aumento da violência praticada por crianças e o daquela que é praticada contra ela refletem uma espécie de retrocesso na idéia que, hoje, um adulto possui do que é uma criança, a saber: uma idéia que faz lembrar aquela que dominou o espírito da idade Média - uma miniatura de um adulto (Postman, 1999).

Dias (2007), por sua vez, chegou a uma conclusão bastante próxima da estimativa sombria de Postman com relação à sobrevivência da infância, ao analisar o fenômeno da participação das crianças nas guerras. O autor concluiu que, na atualidade, esse fenômeno indica que a criança é tomada, sem nenhuma proteção, como objeto do gozo do Outro na sociedade capitalista de mercado. O estilhaçamento da infância é, nessa análise, sinônimo de eliminação das condições simbólicas que presidem a estruturação da aventura do desejo infantil (Dias, 2007). 
O exame dessa inquietação nos conduz a levar em conta que as condições de acolhimento da criança encontram-se alteradas, na medida em que é o próprio sentido da infância e das prerrogativas a serem cumpridas para seu vir-a-ser que se acham ameaçadas. Golse (2004) aponta que o ganho que alcançamos com o extraordinário conhecimento sobre as competências sensórias e cognitivas do bebê está severamente comprometido com as condições do mundo que o aguardam. Ele avalia que as transformações econômicas, sociais e políticas têm perturbado severamente o trabalho de construção da infância, pois as exigências da cultura de massa e da economia liberal comprometem a qualidade daquilo que é oferecido ao sujeito, inclusive sob a forma de uma usurpação do tempo que lhe é necessário para viver plenamente sua infância.

A sociedade ocidental de consumo sabe, infelizmente, muito bem hoje, como produzir objetos inúteis e precários. Cuidemos juntos para não produzir, ainda mais, indivíduos inúteis e frágeis, com toda carga de sofrimentos psíquicos tão profundos que os ameaçariam então (Golse, 2004, p.16).

Ao acompanharmos as notícias que permeiam nosso cotidiano recolhemos, a todo o momento, indícios dessa inquietação. Vejamos o que se coloca em jogo, por exemplo, na polêmica recentemente deflagrada com o envio para o Congresso Brasileiro de um projeto de lei que pretende regularizar o parto anônimo ${ }^{1}$. Os que são a favor da medida alegam que a regularização do parto anônimo possibilitaria minimizar as modalidades das formas de abandono a que vem sendo exposto o bebê (na lagoa, numa caixa de sapato, numa esquina, numa lixeira, etc). Uma médica francesa, interrogada sobre sua opinião sobre o que leva uma mãe a

\footnotetext{
${ }^{1} \mathrm{O}$ debate em torno do projeto que visa regulamentação do parto anônimo foi transmitido pelo noticiário noturno da TV Globo no dia 21 de janeiro de 2008.
} 
abandonar seu bebê, responde curta e secamente, a partir de sua prática de mais de vinte anos na realização de partos em segredo na França: "Não há um perfil dessas mães. O único traço que as identifica é uma incapacidade de se tornarem mães".

Esses episódios nos levam a reconhecer que há uma condição inteiramente nova do social que autoriza o surgimento de modos mais ou menos velados de abandono ou de fracasso no acolhimento das demandas da criança. Concordamos com Rosa (2007), quando assinala que esses fatos são indicativos de que a criança já não polariza um investimento libidinal que a posicione como falo para a mulhermãe que, então, agenciaria um primeiro tempo de estruturação, a alienação, que permitiria consolidar um sujeito no filhote humano. "Não basta ter a criança para que se institua a mãe. Há processos concomitantes que instituem a mãe e possibilitam à criança, além da vida puramente biológica (vida nua), a vida político-social-libidinal" (Rosa, 2007, p. 116). A autora argumenta que a parentalidade é um lugar discursivo e que, portanto, sofre e se articula às interferências da ordem política-social.

As observações sobre o declínio da infância, através da análise de Postman e de Dias, nos levam a considerar que na atualidade a criança é capturada no lugar de objeto de gozo do Outro, seja sob a forma de sua exploração como objeto erótico, pelo seu aliciamento ao mundo do consumo desenfreado ou sob o modo de um gozo sacrificial. Embora a posição da criança em relação ao desejo e ao gozo do Outro seja uma vicissitude de sua entrada na linguagem, estimamos que as transformações no campo da cultura resultantes do liame da ciência com o capitalismo na sociedade de consumo parecem franquear a transgressão do interdito 
que assegura que o corpo da criança não seja o lugar de realização selvagem do gozo do adulto. Há uma pane nas condições que são ofertadas pelo Outro à criança e isto parece deixá-la deserdada de toda referência simbólica humanizante que permita situá-la em relação a seu lugar no desejo que a antecedeu. Vamos acompanhar os efeitos dessa injunção na clínica do bebê, uma vez que essa clínica se inscreve na borda de diferentes domínios discursivos.

\section{A CLÍNICA DO BEBÊ: HORIZONTES E PROMESSAS}

Golse (2004) afirma que a importância dos estudos sobre o bebê ultrapassa a questão do bebê em si mesmo, pois reflete sobre as prerrogativas da construção do humano no mundo, hoje. O autor menciona que a elaboração, no campo da saúde mental, dos primeiros quadros da pedo-psiquiatria, do autismo infantil precoce por L. Kanner em 1943, e das depressões do bebê através das observações de R. Spitz, J. Bowlby e J. Robertson franquearam os caminhos para pensar sobre os fatores que põem em risco a constituição de uma subjetividade. Quando se concedeu ao bebê o direito de possuir uma vida psíquica, foi necessário admitir que ele também seria vulnerável ao adoecimento e ao sofrimento. Nesse sentido, os esforços se voltaram para compreender as vicissitudes que perturbam ou favorecem o estabelecimento dos primeiros laços do bebê com seus outros, pois é nesse encontro que se produzem os alicerces da vida psíquica e da saúde mental. "Para o surgimento do sujeito psíquico, é necessário o encontro entre este alicerce - o biológico - e uma estrutura familiar, transmissora do sistema simbólico" (Bernardino, 2006, p.28). 
A démarche das pesquisas sobre as vicissitudes do vir a ser na criança é, também, na consideração de Golse (2004), interligada às catástrofes humanas que abateram o século $X X$, quer dizer, à constatação de que realizamos e sofremos a experiência de ir além dos limites em matéria de destruição do semelhante. A culpabilidade pelos sofrimentos infligidos aos bebês, durante a segunda guerra, é um fator influente na origem dos esforços em resgatar uma compreensão mais justa do impacto da ruptura dos laços humanos nos primórdios da vida subjetiva. Por sua vez, as angústias existenciais que animam cada fim de século pontuaram o fim do século XIX com as preocupações pelo que se passava no interior do corpo e da psique, encontrando na psicanálise uma resposta que acolhia essas angústias. Já, o fim do século XX, viu-se concernido pela ânsia de saber sobre as origens, em suas mais diferentes implicações, seja no que se refere ao tempo, ao universo e à vida. Assim, o interesse pelo bebê, encontra-se sob a égide dessa conjuntura, pois não se trata apenas de melhor compreendê-lo, mas de estabelecer as premissas de uma ética que não seja alheia às condições que são exigidas ao seu advento como sujeito do desejo.

Os avanços científicos têm proporcionado um vasto conhecimento sobre as habilidades sensórias e lingüísticas que compõem o repertório do bebê ao nascer. Esses conhecimentos têm possibilitado entender de que modo o bebê manifesta a vivacidade de seu desenvolvimento, assim como os impasses na estruturação de seu vir-a-ser. As competências do recém-nascido revelam que ele é um ávido interlocutor que está apto a complexas interações com seu entorno no início da vida e, de modo algum, é um ser passivo e alheio à presença de um outro humano. Wanderley (2000) analisando o desejo de comunicar do bebê lembra que ele 
mobiliza os rudimentos de sua competência lingüística (capacidade de discriminar os sons em forma de categorias e sua sensibilidade à prosódia da voz materna) para manter um vivo diálogo com o parceiro materno, mobilizando todo seu corpo (olhares, gritos, choro, sinais, etc.) nessas primeiras trocas. Os experimentos realizados, por exemplo, com a sucção não-nutritiva, corroboram o fato de o bebê ser particularmente sensível à musicalidade da voz materna.

O privilégio precoce do recém-nascido com relação à gestalt do rosto humano é um outro aspecto observado, há bastante tempo, por Spitz (1975). Mathelin (1997) menciona, em seu trabalho na clínica do bebê pré-termo, uma outra variante do experimento da reação do bebê frente ao rosto humano. A psicanalista retoma a experiência do rosto impassível, realizada por Brazelton, para falar do impacto da qualidade da presença humana oferecida na rotina de cuidados ao bebê pré-termo. Esse experimento investigou a reação dos bebês com idade entre um e três meses, numa situação específica, em que suas mães, durante o contato com eles, repentinamente, Ihes apresentaram um rosto impassível. Verificou-se que os bebês reagiram a essa situação, inicialmente, através de uma agitação, seguida de uma tentativa de reatar a comunicação com suas mães. Após algum tempo, eles caíam em desespero e, em seguida, se desligavam do meio. O experimento constatou que a situação também era extremamente dolorosa para as mães que levavam algum tempo para recuperar seu bebê através da fala. A psicanalista concluiu dessa experiência que "as crianças hospitalizadas, se lidassem durante toda uma parte do dia com "rostos impassíveis", não poderiam estar no mundo e evoluir normalmente" (Mathelin, 1997, p.91). 
Os progressos da medicina fetal, por outro lado, ampliaram o escopo desses conhecimentos, apontando para a existência de intercâmbios pré-natais entre o organismo materno e o feto. Esses avanços postulam que as experiências prénatais deixam uma memória passível de ser recolhida nas preferências que o futuro neonato manifestará nas primeiras trocas com seus parceiros humanos, seus pais. O reconhecimento e o privilégio manifestados pelo bebê, após o nascimento, em relação à voz materna e paterna, são bons exemplos disso, pois é sabido que a capacidade de audição já se evidência nas respostas do feto a sons de alta intensidade desde a $24^{\mathrm{a}}$ semana de gestação, e que por volta da $35^{\mathrm{a}}$ ele consegue discriminar sílabas simples [...] (Ministério da Saúde, 2002, p.108). O fenômeno da Habituação, ou seja, a diminuição de respostas sucessivas diante de um estímulo repetitivo e idêntico, já manifesta seus primeiros vestígios em torno da $13^{\mathrm{a}}$ ou da $14^{\mathrm{a}}$ semanas de gestação em relação aos estímulos táteis, e para os estímulos auditivos, em torno da $22^{\mathrm{a}}$ ou da $23^{\mathrm{a}}$ semanas. Tal fenômeno, de acordo com os especialistas, "envolve algum grau de memória e funciona como um "filtro" através do qual o organismo elimina respostas supérfluas ou redundantes ante estímulos biologicamente irrelevantes" (Ministério da Saúde, 2002, p. 109). Wilheim (2002) sublinha que os atuais conhecimentos sobre a fisiopatologia do feto confirmam que ele é sensível aos efeitos do stress materno e às substâncias neuro-hormonais secretadas pelo organismo materno, o que, segundo a autora, põe por terra a idéia, por muito tempo cultivada, de que o útero seria um paraíso para o embrião.

A importância das manifestações precoces dos bebês já havia sido reconhecida por alguns psicanalistas cuja prática oriunda da pediatria havia lhes apontado que a clínica com o bebê era um terreno bastante profícuo da intervenção 
pela palavra. Françoise Dolto e Donald Winnicott encontram-se entre aqueles que não recuaram ante a experiência com aqueles que ainda não falam (infans) e consideraram que o bebê é inteiramente receptivo aos efeitos da palavra. Esses pioneiros desenvolveram dentro de seus respectivos marcos teóricos uma prática clínica que estava alicerçada na premissa de que o bebê não se constitui sozinho, quer dizer, que o vir-a-ser do sujeito é indissociável das condições que modalizam o laço inaugural com o Outro. Winnicott dedicou integral atenção à função da mãe nesse processo. Dolto, por sua vez, priorizou a condição do bebê como ser de linguagem e, portanto, centralizou a perspectiva da intervenção psicanalítica nos efeitos da palavra como caminho obrigatório para situar a criança em relação a seu destino.

A prática psicanalítica de Françoise Dolto esteve alinhada, desde o início, à premissa de que a palavra humaniza o sofrimento. A psicanalista apostava que o caminho para auxiliar as crianças que adoeciam passava por restituir o acesso a uma palavra verdadeira que pudesse resgatar o sentido desse sofrimento religandoa às coordenadas simbólicas de sua história, uma vez que para ela o vazio de palavra precipitaria o sujeito ainda em constituição numa condição de desamparo. $\mathrm{Na}$ introdução ao livro Quando surge a criança, que documenta seu trabalho realizado na France-Inter, destinado a discutir os problemas encontrados pelos pais no curso da educação de seus filhos, Dolto (1996) formula sua posição em relação ao espírito que a orienta na prática psicanalítica com crianças do seguinte modo:

O que os pais, o que os adultos não sabem é que, desde o nascimento um bebê é um ser de linguagem e que muitas de suas dificuldades, quando lhes são explicadas, encontram melhor solução com o desenvolvimento. Por menor que seja, se a mãe ou o pai lhe 
falarem sobre os motivos que conhecem ou que supõem para o seu sofrimento, uma criança é capaz de superar sua provação e conservar a confiança em si e em seus pais. Será que ela compreende o sentido das palavras ou a intenção de auxílio, cuja prova é esse falar? Quanto a mim, apostaria que muito cedo ela está aberta ao sentido da linguagem materna assim como ao sentido humanizante da palavra dirigida com compaixão e verdade a sua pessoa (Dolto, 1996, p.12).

Em entrevista concedida a Elisabeth Roudinesco em abril de 1986, Dolto (1989) volta a se manifestar sobre vários aspectos de sua prática que ela traduz como fiel a sua vocação primeira, a de sua formação como médica-pediatra, como sendo a de realizar uma medicina da educação. Ela declara a Roudinesco que quando publicou sua tese "Psicanálise e Pediatria" em 1971 não tinha nenhuma pretensão de fazer avançar a psicanálise, mas a de aplicar a psicanálise à medicina infantil, pois Ihe parecia fundamental que os médicos pudessem saber algo dos problemas inconscientes da infância. O projeto pioneiro da Maison Vert, fundada em 1979, de certo modo realiza essa medicina da educação, pois a psicanalista pretendia poder chegar mais cedo às crianças, isto é, antes que elas apresentassem seus sintomas após a entrada na escola e que já aos oito anos fossem julgadas pelo sistema escolar inaptas para passar de ano.

Achava que, se houvesse um lugar para se falar gradativamente daquilo que se passa entre um bebê, sua mãe, sua família, seria possível evitar a carnalização desses significantes desvitalizantes que as crianças ouvem e que são o leito das neuroses precoces, das estruturas mal-vividas de crianças e também, certamente, das doenças psicossomáticas. Quando eu estava no hospital, as urgências eram isto: crianças que faziam alguma coisa somática num momento de crise moral ou crise social familiar (Dolto, 1989, p.33).

A Maison Vert é definida por sua fundadora como um espaço intermediário entre o lar e os lugares que acolhem as crianças, separando-as de seus pais. A 
psicanalista considerava-o um lugar de lazer e descanso para pais e filhos onde se fala do que acontece, fala-se à criança do que ela vive em presença de seus pais e dos outros que se dispõem ao seu redor. Vemos que a intervenção pela palavra, tal como Dolto a propõe, visa a colocar em circulação esses significantes que se carnalizam no corpo do bebê. O trabalho psíquico ao qual os pais, e aqueles que acompanham e estão numa relação com o bebê ou com a criança pequena, levam à simbolização daquilo que faz sintoma em seu corpo. A perspectiva da psicanalista enfatiza que o trabalho psíquico acima de tudo protege o corpo.

No esteio da transmissão da psicanálise, através do ensino e da supervisão de Dolto, inscreve-se o trabalho de Myriam Szejer no âmbito da maternidade no Hospital Béclère. Para Szejer (1999) é extremamente importante estar atento ao que se passa nos primeiros três ou quatro dias que se seguem ao nascimento, pois a autora entende que se trata de um período incerto em que se decide o nascimento para a vida simbólica. Ela chama esse período de limbo, para indicar que há uma escolha, uma assunção a ser feita, um limiar a ser atravessado, para que a entrada na vida se dê. "Ele é um momento de escolha para o recém-nascido e também para os pais. Escolha de dar lugar ao seu desejo inconsciente para a criança, escolha de reconhecer essa criança desejante e singular para os pais" (Szejer, 1999, p.133). A psicanalista avalia que os progressos da medicina acabam paradoxalmente complicando os processos que se seguem ao pós-parto, pois o excesso de medicalização referente aos cuidados com o recém-nascido e a presença das parturientes resultam por vezes em suprimir o lugar da palavra. 
A experiência de Catherine Mathelin, por sua vez, com a clínica do bebê prematuro, leva o trabalho psicanalítico ao seu limite, pois introduz junto ao campo da prática da neonatologia a dimensão da reanimação do desejo de viver no bebê e nos pais como uma prerrogativa da constituição do sujeito do desejo na fronteira de um domínio em que o limiar entre vida e morte é, a cada nascimento, uma prova de assunção subjetiva a ser realizada. A psicanalista aposta nos efeitos de uma relação de co-responsabilidade entre a medicina e a psicanálise de tal modo, que não se trata de intervir quando os pais criam problemas para o serviço, mas de submeter as questões que essa prática atualiza ao questionamento contínuo da tensão que se estabelece entre o saber médico relativo ao corpo e os efeitos advindos de um outro saber, o saber inconsciente, que revela a verdade do corpo particular de cada um.

O analista não está mais ali para reparar os eventuais estragos de longas hospitalizações, mas para "reanimar" trabalhando com os reanimadores num outro registro. Reanimar a criança e o discurso que a anima. Não se tratava mais, portanto de atendimento sob prescrição quando as famílias vão mal, quando os pais estão infelizes ou agressivos e o trabalho dos médicos sofre com isso. Se tal fosse o caso não estaríamos ali para ajudar os pacientes, mas a medicina (Mathelin, 1999, p.22).

Vemos então, que a infância veio a se tornar uma zona limítrofe do confronto entre o público e o privado, na medida em que várias disciplinas (a medicina, a pedagogia, a psicologia, o direito ${ }^{2}$, etc.) se conjugam para ordenar a rede de atenção à saúde integral da criança. O cuidado com as crianças deixou de pertencer à esfera da família e da escola, tornando-se objeto do discurso médico-psicológico infantil (Vorcaro, 1997). Quando essa atenção requer a priorização dos cuidados médicos devido à urgência que se impõe para a sobrevivência da criança, uma

\footnotetext{
${ }^{2}$ As novas legislações referentes aos direitos da criança e as mudanças no direito de família refletem essa nova configuração entre o privado e o público, entre a parentalidade e a conjugalidade.
} 
tensão se precipita entre os diferentes planos que se colocam como alvo dessa urgência, a saber: o que pertence à ordem do orgânico, do desenvolvimento e da montagem subjetiva. Essa tensão provém do fato de que entre esses diferentes planos há uma defasagem, ou seja, aquela tensão a que se refere Mathelin entre o saber que advém do saber médico sobre o corpo e os efeitos oriundos de um outro saber, o saber inconsciente. Para a psicanálise, a passagem do ser vivo para o sujeito procede do encontro do organismo com a linguagem, encontro marcado por uma desarmonia constitutiva, uma vez que o nascimento do sujeito coloca em jogo uma subtração em relação ao ser vivo. "Admitir a preexistência do Outro em relação ao sujeito faz com que o desenvolvimento da criança não se reduza nem à sua maturação biológica, nem à sua história. Entra em jogo um outro nível lógico, diferente da pré-história da criança" (Ansermet, 2003, p. 61).

Lebrun (2004) coloca que a démarche da ciência traz duas conseqüências importantes: o deslocamento dos limites do possível como sinônimo da expulsão da dimensão do impossível, e a dependência humana em relação à tecnologia. Essa dependência, levada a seu limite, interroga se há possibilidade de existência de uma relação espontânea com o mundo, sem o risco de a vida humana sucumbir. O autor formula desse modo a questão: "[...] se, ontem, a ciência colaborava para apreender a natureza, hoje é a natureza que está totalmente marcada pelo desenvolvimento da ciência e somos nós, sujeitos, que arriscamos a estar sob a autoridade dela [...]" (Lebrun, 2004, p. 66).

O campo da medicina da procriação aglutina, de modo decisivo, as conseqüências desse deslocamento, pois a concepção, segundo Chatel (1995), 
deixa de ser obra do acaso do encontro entre um homem e uma mulher. A invenção da contracepção médica dá início a uma revolução que repercute na economia sexual e do gozo em relação à qual se situa o desejo do filho, pois a lógica da concepção prescinde do ato sexual para a realização desse desejo. "Passou-se, assim, da criança, como conseqüência do desejo sexual do homem por uma mulher, à criança como objeto do querer consciente de uma mulher" (Chatel, 1995, p. 26). Em relação às gestações assistidas, a psicanalista opina que essa prática ignora que a fecundidade seja um processo complexo que envolve o encontro do desejo sexual inconsciente. A dimensão do desejo é desalojada pelo saber científico que elide o que há de mistério e de acaso na procriação, além de deixar na opacidade o estatuto da criança assim fabricada na fantasia parental.

Graças à assistência técnica, o desafio voluntarista fez calar a expressão de nossos símbolos mais carnais, abafou o laço entre a fala e o corpo, dissociou o erotismo da parentalidade. Pois o erotismo e a fecundidade são coisas delicadas, silenciosamente ligadas, feitas de desejos eróticos infantis, de reminiscências poéticas, de ligações de palavras sutis (Chatel,1995, p. 56).

O êxito dos avanços técnico-científicos inaugura outras condições de risco à vida, pois esta, como veremos, possui o eixo de sustentação de seu valor para a cria humana no laço significativo com um Outro que não seja destituído de um desejo que anima sua existência simbólica. Verificamos que na clínica do bebê pré-termo esse risco desponta muito vivamente, uma vez que a tomada do bebê nos dispositivos médicos que viabilizam sua sobrevivência produz uma barreira à tomada pelos pais do corpo de seu filho como o lugar no qual se inscrevem os significantes da filiação e da sexualidade. Esses avanços intervêm na própria fronteira entre vida e morte restando, contudo, a tarefa de pesar como esses limites são ultrapassados. 


\section{NA FRONTEIRA ENTRE VIDA E MORTE}

As tecnologias de reanimação neonatal tornaram viável a vida de crianças que, até bem pouco tempo, não seriam capazes de sobreviver com os recursos de seu próprio organismo. Os nascimentos medicamente assistidos, como observou Szejer (1997), às vezes tornam o encontro entre pais e filhos difícil. Num nascimento prematuro, como veremos no próximo capítulo, os pais são confrontados concomitantemente com a esperança e com o desespero em relação à expectativa de vida de seu bebê. Podemos dizer que, do ponto de vista psíquico, esse nascimento põe à prova o amor dos pais, pois seu bebê, muitas vezes, leva tempo para dar os sinais de que eles necessitam para sustentar o investimento libidinal requerido para a construção do vir-a-ser na criança. Nesse contexto, a perícia e a sensibilidade da equipe médica é capital, na medida em que o olhar dos pais encontra-se mediado pelo olhar da própria equipe terapêutica para a criança.

Na clínica do prematuro, o saber dos pais sobre seu filho é, de saída, posto em suspenso pelo saber do especialista, pois é este que possui o saber que pode salvar a criança. Essa condição, de imediato, interpõe uma distância entre pais e filhos que pode repercutir na simbolização desse nascimento diferente pelos pais. De todo modo, as condições da prematuridade clínica da criança vão exigir a tomada de muitas decisões médicas que se encontram fora dos limites de compreensão imediata dos pais ou pelo menos dissonante em relação a tudo aquilo que eles imaginavam ou previam do que seria o momento do nascimento de seu filho. Os pais têm dificuldade de decifrar o seu bebê e, por algum tempo, as coordenadas que os orientam são aquelas fornecidas pelos aparelhos que monitoram as funções do 
organismo de seu filho, assim como a palavra do especialista. Na clínica do prétermo, o risco da criança não franquear a entrada na vida simbólica é redobrada, pois a presença de riscos reais em relação à expectativa de vida dessas crianças situa essa vida numa certa zona de indeterminação por algum tempo. Szejer (1997), como vimos, utiliza o termo "limbo" para descrever essa condição. O dicionário Aurélio da Língua Portuguesa define limbo como orla, borda, rebordo. No sentido da teologia católica posterior ao século XII, limbo é o lugar em que se encontram as almas das crianças muito novas que, embora não tivessem alguma culpa pessoal, morreram sem o batismo que as livrasse do pecado original.

A clínica do pré-termo não desafia apenas os pais, mas também a equipe médica, pois eles também são confrontados com as questões da vida e da morte e são interpelados pelos limites da reanimação. Mathelin (1997) bem observa a contradição vivida pela equipe médica quando aponta que a reanimação está na contramão da morte. O contexto dos nascimentos assistidos põe em cena os riscos inerentes à própria tomada da vida pelas novas tecnologias, visto que o deslocamento dos limites do possível flerta com a elisão da dimensão do impossível que é inerente à constituição do humano.

Nesse sentido, as decisões que suportam o ato clínico pela equipe médica não são alheias à configuração e à montagem discursiva que presidem a tomada do próprio sentido da vida no contexto sócio-econômico-político. É dessa perspectiva que se origina essa demanda tão atual que conclama esforços para estabelecer estratégias de humanização do nascimento com vistas à criação de dispositivos que possam atenuar e deslocar os efeitos dessa nova disposição do laço social. Uma 
prova dessa inquietação nos é fornecida por Mathelin (2007), por exemplo, quando aponta que a introdução no campo da clínica do bebê pré-termo de uma nova categoria, a da "reanimação em espera", de acordo com sua avaliação, coloca em debate justamente o problema dos limites da reanimação neonatal (informação verbal) ${ }^{3}$. Ela descreve essa categoria como introduzindo um novo limiar da vida. A "reanimação em espera" se refere à condição dos extremos prematuros que estariam aquém, não apenas do investimento libidinal parental, mas aquém da condição mesma da posição de objeto de gozo da medicina. É como se essa vida estivesse aquém da possibilidade de ser determinada em relação a qualquer parâmetro humano.

Vimos, a partir do conceito de bio-política de Foucault (1985), que os fenômenos ligados à vida humana são o ponto de convergência de uma série de estratégias que conjugam o poder político, a instância do judiciário, a biologia e a medicina. O autor considera que a centralização do poder em torno da gestão dos fenômenos da vida resulta de um deslocamento da prerrogativa original do soberano que se exercia como poder de causar a morte. O poder soberano, enquanto direito de vida e morte, origina-se diretamente da patria potestas, que autorizava o pai de família romano ao direito de dispor da vida de seus filhos e de seus escravos, já que Ihes havia dado a vida. "O poder era, antes de tudo, nesse tipo de sociedade, direito de apreensão das coisas, do tempo, dos corpos e, finalmente, da vida; culminava com o privilégio de se apoderar da vida para suprimi-la" (Foucault, 1985, p. 128).

\footnotetext{
3 A psicanalista Catherine Mathelin apresentou a categoria de "reanimação em espera" na conferência proferida na Escola de Psicanálise de Campinas, em agosto de 2007.
} 
Para Foucault (1985), a sociedade Ocidental conheceu uma transformação profunda dos mecanismos de poder, pois este não se exerce mais de modo subtrativo. O poder passa a se exercer na gestão da vida visando sua multiplicação, sua ampliação e sobrevivência. O direito de morte, que antes se manifestava como prerrogativa do soberano para garantir sua sobrevivência, torna-se manifestação do direito do corpo social de garantir sua própria vida, mantê-la ou desenvolvê-la. Essa gestão da vida organiza-se em dois pólos: as disciplinas do corpo e a regulação da população. No primeiro pólo, será priorizada a noção do corpo-máquina, na medida em que se trata de obter seu adestramento, a ampliação de suas aptidões, e a integração aos sistemas de controle eficazes e econômicos. O segundo pólo, por sua vez, vai colocar em cena o corpo-espécie, enquanto suporte dos processos biológicos.

Agamben (2007) vai avançar nessa discussão, argumentando que a idade da biopolítica se caracteriza, cada vez mais, como aquela em que a decisão sobre o momento em que uma vida cessa de ser politicamente relevante avança para além do estado de exceção ${ }^{4}$, obscurecendo a fronteira em que a tomada da vida pela política se converte em decisão sobre a morte. O filósofo aponta, em seu livro 0 poder soberano e a vida nua, que a redefinição do conceito de morte, na medicina, revela esse limiar ambíguo, em que a tomada da vida pela política coincide com uma decisão sobre a morte, colocando em cena o próprio destino do humano. A vida é colocada num limite em que ela não está, nem completamente dentro, nem

\footnotetext{
${ }^{4} \mathrm{O}$ autor adota a definição de Schmitt, que considera que o estado de exceção não é o caos, mas uma condição singular em que a relação com o ordenamento jurídico é mantida sob a forma de uma suspensão da norma jurídica. Na exceção, aquilo que está excluído não está absolutamente fora de relação com a norma. A norma se aplica à exceção desaplicando-a, retirando-se desta (Agamben, 2007).
} 
completamente fora do ordenamento jurídico, mas numa condição de abandono. A vida nua, na opinião do filósofo, cada vez mais coincide com a existência biológica do indivíduo. Para melhor situar essa dimensão vale lembrar que os gregos dispunham do termo Zoé para designar a condição do homem como ser vivente, ao lado dos demais seres vivos (animais, deuses), e reservavam o termo Bíos quando se tratava de referenciar a vida incluída no domínio da Polis, de maneira a projetar a vida qualificada como se situando para além da condição decorrente do puro fato do nascimento.

Agamben (2007) assinala que a categoria "vida indigna de ser vivida", introduzida pelo especialista em direito penal Karl Binding, em 1920, atualiza essa questão, quando inaugura no campo jurídico a discussão sobre o problema da eutanásia. Trata-se de uma categoria que se aplica a indivíduos considerados “incuravelmente perdidos" em seguida a uma doença ou ferimento, e que estando em plena consciência de sua condição, desejam a "liberação" de sua condição.

Se a eutanásia se presta a esta troca, isto ocorre porque nela um homem encontra-se na situação de dever separar em um outro homem a zoé do bíos e de isolar nele algo como uma vida nua, uma vida matável. Mas, na perspectiva da biopolítica moderna, ela se coloca, sobretudo na intersecção entre a decisão soberana sobre a vida matável e a tarefa assumida de zelar pelo corpo biológico da nação, e assinala o ponto em que a biopolítica converte-se necessariamente em tanatopolítica (Agamben, 2007, p.149).

O limite entre vida e morte volta à cena com a categoria do coma dépassé (além coma) introduzida pelos neurofisiólogos franceses P. Mollaret e M. Goulon em 1959. No coma dépassé se encontram totalmente abolidas as funções, tanto de vida de relação, como as de vida vegetativa. O surgimento desse novo estado é conseqüência do surgimento das tecnologias de reanimação (respiração artificial, 
circulação cardíaca mantida através de perfusão endovenosa de adrenalina, técnicas de controle de temperatura corpórea, etc.). Quando os procedimentos de reanimação são suspensos nesses casos, há imediato colapso cardiovascular e cessação de todo o movimento respiratório. O estado do além coma promove, ato contínuo ao seu surgimento, o debate sobre os critérios requeridos para localizar o estatuto da vida nessa zona obscura em que ela praticamente se avizinha numa indistinção com a morte.

O coma dépassé desperta a necessidade de redefinir o critério de morte que, até esse momento, estava fixado nos parâmetros da cessação dos batimentos cardíacos e na parada da respiração. Agamben (2007) aponta que essa urgência estava relacionada ao fato de que o estado do além-coma era, além de tudo, a condição ideal para a coleta de órgãos destinados à realização de transplantes, cuja tecnologia é contemporânea às técnicas de reanimação. Era necessário garantir que o cirurgião que viesse a efetuar a coleta de órgãos ou o transplante não incorresse no crime de homicídio. Em 1968, um relatório de uma comissão especial da Universidade de Harvard fixa a morte cerebral como novo critério de determinação da morte.

A sala de reanimação onde flutuam entre a vida e a morte o néomort, o além-comatoso e o faux vivant delimita um espaço de exceção no qual surge em estado puro, uma vida nua, pela primeira vez integramente controlada pelo homem e pela tecnologia. E, visto que se trata, justamente, não de um corpo natural, mas de uma extrema encarnação do homo sacer (o comatoso pôde ser definido como "um ser intermediário entre o homem e o animal"), a aposta em jogo é, mais uma vez, a definição de uma vida que pode ser morta sem que se cometa homicídio (e que, como o homo sacer, é "insacrificável", no sentido de que não poderia ser colocada à morte em uma execução de pena capital) (Agamben, 2007, p. 171). 
Observemos que as reflexões de Agamben vão convergir com as questões problematizadas por Hanna Arendt em torno de outras condições limites, em que é a própria condição do estatuto do humano que vem à cena. Arendt (1989), analisando a experiência dos refugiados de guerra, dos apátridas e do horror daqueles que puderam testemunhar sobre os campos de concentração, mostra a transgressão desse limiar em que a vida cessa de ser politicamente relevante. No livro Origens do Totalitarismo, a autora afirma que os refugiados de guerra e os apátridas constituem uma categoria limite que põe em crise o nexo nascimento-nação enquanto categoria fundamental do Estado-nação. A filósofa aponta que o contexto da vida desse enorme contingente humano que passou a se deslocar, após a segunda guerra, revelou a íntima interdependência entre os direitos dos povos e os direitos humanos.

Arendt (1989) argumenta que, mal o homem havia surgido emancipado pela promulgação dos direitos humanos, sem referência a nenhuma ordem superior, ele já se diluía como membro do povo. O desamparo vivido pelos povos sem pátria não era apenas a perda do lar, mas a impossibilidade de achar um novo lar, quer dizer, de encontrar um lugar no seio de uma comunidade. O procedimento adotado pelos nazistas - de privar os judeus de sua condição de cidadãos, antes de conduzi-los ao campo de concentração - atesta, em sua análise, o liame indissolúvel entre o cidadão e o homem.

Para a autora, a calamidade desse novo estado de coisas é que o Homem pode perder todos os direitos do Homem sem perder sua dignidade humana, pois o que define essa perda é sua expulsão da própria comunidade. Quando um homem não encontra um lugar num laço significativo com o Outro, ele perde toda a 
referência que o situa como humano, pois o sujeito encontra-se privado da conseqüência de ser reconhecido como responsável por qualquer ato. Arendt (1989) assinala, que a condição do refugiado é de tamanha exceção que, se ele vem a cometer um crime, por exemplo, ele volta a encontrar, junto a um determinado coletivo, uma proteção que antes do ato ele não possuía.

A autora conclui que o paradoxo dos direitos do homem se revelou no momento em que aquele cuja única coisa que havia restado após a experiência de toda sorte de privações foi sua condição de homem que, nesse momento, apenas significava que ele pertencia à raça humana como os animais de uma espécie. A experiência e o testemunho daqueles que sobreviveram aos campos de concentração e de refugiados mostrou que a condição de nudez do humano implica no risco desmedido do desamparo simbólico.

[...] para o ser humano, que perdeu seu lugar na comunidade, a condição política de seu tempo e a personalidade legal que torna consistentes suas ações e seu destino, restam aquelas qualidades que só se podem expressar no âmbito da vida privada, simples existência, e sem implicação com o interesse público. Nossa simples existência, ou seja, aquilo que nos é dado por nascimento como nosso corpo, nossos talentos, pertence ao mistério, ao incalculável. Os gregos já manifestavam enormes suspeitas em relação àquilo que se referia à vida privada, ou seja, a tudo que, não sendo obra da vida política, revela o incômodo no fato de que cada um de nós é feito inteiramente de modo singular e único. O que pertence à vida privada é uma ameaça à esfera pública, na medida em que esta é baseada na lei da igualdade, enquanto que a esfera privada é baseada na lei da distinção e da diferenciação universal (Arendt, 1989, p. 334).

Consideramos que essas reflexões são relevantes para situar o estatuto do humano e refletir sobre os modos de acolhimento à vida daqueles que se encontram em situações limite como, por exemplo, a condição das crianças que nascem prematuramente. A partir dessas reflexões, vemos que a dimensão da humanização 
encontra-se indissociavelmente ligada à tomada do sujeito numa relação simbólica ao Outro como condição que o resguarda a que ele não subsista tão somente como vida nua, quer dizer, vida destituída de qualquer valor simbólico para o Outro. Conforme aponta Lajonquière (2005) aquilo que faz de um "homem" um homem não é a pertinência genérica a uma espécie humana, mas “[...] resulta de marcas práticas discursivas sobre a indeterminação da cria sapiens. [...] Os princípios básicos de nossa "humanidade", ou seja, os de identidade, diferença e causalidade, derivam dessa sujeição" (Lajonquière, 2005, p.237). Nesse sentido, o bebê prematuro e seus pais requerem uma atenção especial, para que as condições a serem cumpridas pelo tratamento não impeçam que o bebê disponha de uma narrativa que lhe permita construir sua história junto de seus pais, quer dizer, que ele possa se subtrair da condição desumanizante de permanecer como objeto de gozo da medicina, ou ainda, numa condição inominável, tal como a que Mathelin designou nas "reanimações em espera".

\section{A VIDA É UM DOM QUE SE RECEBE DO OUTRO}

Em seu texto "Nota sobre a criança", Lacan (2003) distingue o ser vivo do sujeito, ao afirmar que a função da transmissão operada pela família é de outra ordem que a daquela da satisfação das necessidades, pois a constituição da subjetividade encontra-se na dependência de um desejo não-anônimo. A vida é um dom que o sujeito recebe de um Outro, desde que tenha havido um lugar para ele no desejo daqueles que o antecederam. É em relação com a prerrogativa desse desejo não-anônimo que se julgam as funções parentais. A função da mãe a promove pela via de um cuidado particularizado e a função do pai enquanto nome é a encarnação 
da Lei no desejo. Vemos que o nó da constituição subjetiva está no simbólico que precede o sujeito, pois, antes de existir em si e para si, o infans existe para e por outrem. "Um pólo de atributos, eis o que é o sujeito antes de seu nascimento [...] De atributos, isto é, de significantes mais ou menos ligados num discurso [...]" (Lacan, 1998, p. 659). Esse dom que o sujeito recebe, a vida, o implica numa dívida simbólica, quer dizer, o inclui numa cadeia simbólica, isto é, num discurso.

A transmissão pela via de um desejo que não seja anônimo requer primeiro haver Outro como lugar do tesouro dos significantes e uma antecipação de que um sujeito possa advir como resposta do real ao significante, ou seja, como efeito da articulação do significante. Haver desejo não-anônimo implica na articulação de um endereçamento que permita enlaçar o sujeito e o Outro. Crespin (2004) lembra que os bebês humanos não são os únicos a nascerem prematuros, mas ela aponta que apenas os seres humanos requerem um sistema simbólico que Ihes permita ajustar sua relação ao real, na falta de serem guiados pelos instintos, como ocorre com os animais. A mãe é para o bebê um pequeno outro (semelhante) que vai servir de grande Outro (sistema simbólico), pois, pelos cuidados que ela dispensa ao bebê, ela Ihe transmite as particularidades do grande Outro que a determinam. A criança é inserida nesse laço inaugural com a mãe como um objeto de amor, pois a mãe vê o bebê como ela o ama.

Freud (1914/1974) afirma que o amor dos pais pela criança é uma prova irrefutável do narcisismo primário. Os pais vêem a criança dotada de todas as perfeições e, em nome desse amor, reclamam a suspensão de todas as limitações impostas pelas exigências culturais ao seu próprio narcisismo. "O amor dos pais, tão 
comovedor e no fundo tão infantil, nada mais é senão o narcisismo dos pais renascido, o qual, transformado em amor objetal, inequivocamente revela sua natureza anterior" (Freud, 1914/1974, p. 108). No amor, há um transbordamento da libido do eu para o objeto e um verdadeiro amor feliz é aquele no qual a libido objetal e a libido do eu não podem ser distinguidas. Este é o efeito ilusório do amor, o fazer Um.

É na relação da criança com a mãe que se circunscreve a estruturação do domínio especular pela identificação do infans com a imagem do semelhante. A identificação especular opera para o infans um corte, uma separação que instala uma distância em relação a seu corpo real. Esse corte é solidário da completa desnaturalização desse corpo, cuja sustentação, a partir da intervenção do Outro, reside na dimensão do olhar, um olhar fundador que, ao conjugar o real do organismo a uma imagem, proporciona à criança o sentido do corpo unificado. Lacan (1998) aponta que essa estruturação é realizada em defasagem com a maturação do organismo, e é essa defasagem que confere um valor de antecipação a essa experiência, pois o júbilo do infans diante da imagem do espelho comemora aquilo que primeiro foi pré-visto pelo e no Outro.

No seminário 8, A transferência, Lacan (1992) afirma que só há amor na perspectiva da demanda, isto é, para um ser que fala, quer dizer, para aqueles que se constituem no campo da linguagem. O amor se perfila sempre na perspectiva da demanda, na medida em que aquilo que o sujeito demanda é sempre, em última instância, demanda de ser escutado para além do que ele diz. Lacan (1992, p. 345) 
afirma que o sujeito demanda ser escutado para nada, mas que nesse "para nada" "[...] já está o lugar do desejo".

As elaborações sobre a metáfora do amor situam o ponto que articula a dimensão do desejável na dialética de amor na identificação do espelho. A retomada das escansões que modulam a relação da identificação à imagem especular destaca o valor da demanda realizada pelo infans em direção ao adulto que se encontra junto a ele nesse momento. O gesto realizado pela criança de voltar-se para o adulto para solicitar que este ratifique a imagem que ela vê como sendo a sua conserva toda a sua importância, pois o assentimento que ela recebe nesse momento tem valor de testemunho do Outro.

A partir desse momento original, é sensível para nós o caráter que chamarei antagonista do eu ideal. Ou seja, já nessa situação especular se desdobra, e desta vez no nível do Outro, para o Outro e pelo Outro o eu desejado, entendo desejado por ele, e o eu autêntico, o authent-Ich, se me permitem introduzir este termo, que nada tem de tão novo no contexto em questão - com a ressalva de que, nessa situação original, é o ideal que está ali, falo do eu ideal e não do ideal do eu, e que o autêntico eu, ainda está por vir (Lacan, 1992, p.342).

O psicanalista francês destaca que o olhar do Outro é interiorizado pelo sujeito como um signo, traço único, einziger Zug, enquanto referência original do assentimento do Outro que comanda a escolha de amor. "Basta que o sujeito vá coincidir ali em sua relação com o Outro, para que este pequeno signo, este einziger Zug, esteja à sua disposição" (Lacan, 1992, p. 344). Esse traço único é o ponto, o lugar, no Outro, que permite ao sujeito ver-se como amável e desejável. A resposta do Outro ao desamparo da cria humana, quando de seus primeiros apelos, implica uma resposta de amor, na medida em que o amor é uma relação que visa ao ser. 
Winnicott (1975), quando abordou a temática da relação da criança com o olhar materno no seu texto "O papel de espelho da mãe e da família no desenvolvimento infantil", mostrou que quando não se produz esse efeito de sentido do amor, a criança encontra-se em absoluto risco de desamparo. Ele considerou o rosto da mãe um precursor do espelho, num momento em que o bebê ainda não se separou de si mesmo. Ele se pergunta: o que o bebê vê quando olha para o rosto de sua mãe? A resposta é que ele vê a si mesmo, desde que a mãe possa se ver no bebê, ou seja, que ela possa reconhecer nele algo que a reenvie a si mesma. Para o autor, no entanto, quando a mãe só pode reagir à presença do bebê refletindo seus estados de humor ou sua rigidez, algo vai fracassar no estabelecimento do sentimento de existir do bebê, pois eles, os bebês "[...] não recebem de volta aquilo que estão dando. Eles olham e não vêem a si mesmos" (Winnicott, 1975, p.154). Nesse caso, a criança não encontra nesse olhar uma referência simbólica que engate seu ser na relação ao desejo do Outro. Winnicott (1975) considera que as depressões maternas constituem um dos fatores que atualizam um vazio de presença, de desejo, que precipita a criança no estado de caos, de desintegração, de angústia de aniquilamento.

A discordância que o bebê experimenta cedo demais ao ser exposto a esse vazio de presença, é vivida por ele em seu corpo como uma catástrofe, pois é a mãe que permite que haja uma certa continuidade entre suas sensações pré e pósnatais. O sentido de unificação do corpo que a criança encontra no olhar da mãe é um tempo fundamental da estruturação do infans, pois é essa imagem corporal que fornece a preservação dos envelopes corporais e psíquicos. No início da vida, é o Outro que deve ser furado, quer dizer, marcado pela falta e não o bebê. 
O risco de desamparo para o bebê, quando ele se encontra privado desse laço de amor, foi também contemplado na análise que Spitz realizou do fenômeno do hospitalismo e dos transtornos de carência afetiva naqueles bebês confiados aos cuidados de substitutos maternos em creches e orfanatos. Spitz (1975) distinguiu a depressão anaclítica dos transtornos mais profundos da carência afetiva total. As manifestações da depressão anaclítica se observam naqueles bebês que mantiveram um laço satisfatório com suas mães no início de sua vida, e que foram submetidos a uma separação temporária. Os sintomas registrados durante esse período de separação no bebê foram os seguintes: inicialmente, as crianças choravam mais e buscavam ativamente um contato com o observador; após algum tempo havia perda de peso e um estacionamento do desenvolvimento; passados três meses dessa separação, o bebê manifestava intenso rechaço ao contato, e seus choros transformavam-se em estranhos gemidos. Quando essas crianças retornavam às suas mães e, desde que essa separação não tivesse ultrapassado um tempo crítico, os transtornos do bebê regrediam rapidamente, surpreendentemente, nas palavras de Spitz.

O mesmo desenvolvimento não foi constatado nas crianças que haviam sido privadas, desde o nascimento, de um laço positivo com suas mães. Os bebês desmamados aos três meses, e confiados à assistência em orfanatos e creches, apresentaram um quadro totalmente diverso. Os bebês, embora tenham recebido uma provisão ambiental adequada, apresentaram distúrbios generalizados do desenvolvimento. Spitz (1975), entretanto, observou que, nesses casos, as crianças foram cuidadas por pessoas que se ocupavam de muitas crianças simultaneamente, o que levou à conclusão de que esses cuidados não foram dispensados num 
contexto que as particularizasse. O caráter mórbido da desagregação apresentado por essas crianças se traduziu num completo comprometimento de seu desenvolvimento motor, cognitivo e emocional que foi identificado nos seguintes sinais: passividade, retraimento no contato com o semelhante, desmantelamento sensorial, olhar e rosto com expressão vazia, coordenação ocular defeituosa, queda da imunidade, marasmo e, às vezes, a morte. Em linhas gerais, o estudo corroborou a importância da qualidade da provisão materna no primeiro ano de vida do bebê.

Podemos verificar que as manifestações mórbidas apresentadas por esses bebês não se originavam de uma falha real da maternagem, visto que o Outro não é o meio ambiente. O que faltou para eles foi a dimensão de um Outro desejante que pudesse situá-los num lugar que permitisse encadear simbolicamente sua presença, de modo que seu corpo e seus afetos pudessem se integrar numa fala que os situasse junto a esse Outro. Os cuidados, distribuídos de maneira anônima pelos substitutos maternos, repercutiram drasticamente no corpo dessas crianças. Por outro lado, as crianças que deprimiram na ausência de seu Outro privilegiado foram capazes de suportar, dentro de certo limite, sua ausência temporária, e puderam se recuperar quando esse laço particular foi reatado.

As observações de Spitz mostram que, para o ser falante, a partir do momento em que as necessidades são articuladas pela demanda, elas sofrem um remanejamento, na medida em que a demanda implica na defasagem introduzida pelo significante, ou seja, implica na presença do Outro. Lacan (1992, p. 95) afirma que "[...] desde o começo, o que entra na criação do significado não é uma pura e simples tradução da necessidade, mas uma [...] remodelagem da necessidade, 
criação de um desejo outro que não a necessidade. É a necessidade, mais o significante". A criação da mensagem é concomitante com a instituição do Outro, pois a demanda é articulada pelo sistema significante do Outro. Na resposta à demanda há defasagem, e é nessa defasagem que se insinua uma outra coisa que não a necessidade, a saber: o desejo, o desejo do Outro. $O$ apagamento da necessidade, pela sua passagem pelo sistema significante, introduz, com relação ao objeto capaz de proporcionar a satisfação, uma outra dimensão que é a do valor desse objeto na relação com o desejo do Outro. (Lacan, 1992).

O primeiro ternário imaginário mãe-criança-falo que preside a instalação da criança no campo da linguagem concerne logicamente a um outro ternário, simbólico, em que a dimensão do pai, como nome do pai situa no Outro "[...] a existência da cadeia significante como lei" (Lacan, 1992, p. 202). É a posição do significante paterno que é fundador da posição do falo como objeto privilegiado no imaginário. A criança, inicialmente, experimenta o desejo da mãe como centro em torno do qual gravita seu ser. "O que deseja o sujeito? Não se trata da simples apetência das atenções, do contato ou da presença da mãe, mas da apetência de seu desejo" (Lacan, 1992, p. 188). É em relação a esse desejo que se organiza para o sujeito a dialética de ser ou não ser o falo para a mãe e é nessa dialética que vai se inscrever o domínio da tapeação do amor entre a criança e a mãe.

Viltard (1996) destaca que a dimensão do logro amoroso é um efeito do assujeitamento do desejo do sujeito ao desejo do Outro. A autora aponta, seguindo Lacan, que aquilo que o sujeito busca no amor não é o seu complemento, mas a parte perdida de si mesmo enquanto ser sexuado. O efeito do amor é indissociável 
da presença do desejo, na medida em que aquilo que é visado no amor é o desejante no outro, o que coloca como condição que o sujeito tenha sido primeiramente situado como o desejável pelo outro. Lacan (1992) afirma que amar é dar o que não se tem e que o amor é mobilizado por aquilo que não se tem, mesmo que se tenha. "O amor, como resposta, implica o domínio do não-saber. [...] dar o que se tem, isso é a festa, não o amor" (Lacan, 1992, p. 345).

Nessa perspectiva o amor é um significante, uma metáfora, quer dizer, um efeito de sentido, na medida em que há substituição significante. A metáfora do amor consiste em que o érastès, o sujeito da falta, o desejante, venha a tomar o lugar do érôménos, o objeto amado, e que, para que essa metáfora se produza, é necessário contemplar que há anterioridade do desejo do Outro.

\begin{abstract}
A metáfora do desejante no amor implica naquilo que ela substitui como metáfora, isto é, o desejado. O que é desejado? È o desejante no outro - o que só se pode fazer se o próprio sujeito for colocado como desejável. É isso que ele demanda da demanda de amor (Lacan, 1992, p. 345).
\end{abstract}

Consideramos que a dimensão do amor é, então, estruturante para o vir-a-ser na criança, pois ela pressupõe que o sujeito foi primeiramente desejado pelo Outro. Vamos discutir nos próximos dois capítulos, através da análise das falas dos pais dos bebês pré-termo, os caminhos de elaboração dos efeitos do nascimento prematuro na estruturação dessa relação de amor. Estaremos priorizando, nessa análise, a dimensão do amor da mãe como suporte da operação pela qual o organismo do neonato vem a ser introduzido no campo do simbólico. Avaliar o impacto desses nascimentos para os pais é extremamente importante, considerando 
que o tempo de hospitalização dessas crianças, por vezes, é bastante longo e ameaça esse laço original.

Golse (2004) chama a atenção para o fato de que, cada vez mais, a clínica do bebê enfrenta as patologias da ausência. O autor aponta que é necessário considerar que a psicopatologia parental é um fator determinante, porém ele sugere que não é possível, nessa circunstância, não fazer um balanço mais crítico e constatar que houve fracasso de outros terceiros que pudessem modular o impacto da carência materna sobre a criança. Consideramos essa uma importante indicação para a clínica do bebê pré-termo, pois os dispositivos de acolhimento à criança e a seus pais devem zelar para que as separações não privem o bebê e seus pais da construção desse laço de amor enquanto prerrogativa fundamental que vai objetar a que a criança fique desamparada das referências simbólicas que presidiram ao seu nascimento. 


\title{
3 - O FEMININO, O MATERNO E A CRIANÇA
}

\begin{abstract}
Não se trata apenas de falar das interdições, mas simplesmente de uma dominância da mulher na condição de mãe, e mãe que diz, mãe a quem se demanda, mãe que ordena e que institui ao mesmo tempo a dependência do homenzinho. A mulher permite ao gozo ousar a máscara da repetição. Ela ensina aqui como o que é, com instituição da mascarada. Ela ensina seu pequeno a se exibir. Ela conduz ao mais-de-gozar porque mergulha suas raízes, ela, a mulher, como a flor, no gozo mesmo. Os meios de gozo são abertos pelo seguinte princípio - que ele tenha renunciado ao gozo fechado e alheio, à mãe.
\end{abstract}

Jacques Lacan (1969-70)

\section{O MATERNO E O FEMININO}

Em 1923, no texto "A Organização Genital Infantil", Freud postula a premissa fálica como universal e característica da organização genital infantil. Para as crianças de ambos os sexos apenas um órgão genital entra em consideração, o órgão masculino, o que leva à conclusão de que "[...] o que está presente, portanto, não é uma primazia dos órgãos genitais, mas uma primazia do falo" (Freud, 1923/1976, p.180). O ser falante só dispõe de um significante, o falo para significar a diferença sexual, já que não há inscrição da diferença entre os sexos no inconsciente. Há primazia do simbólico no caminho da realização sexual humana.

Em 1924, as elaborações freudianas indicam que o caminho que conduz a menina à normalização de sua posição sexual é simétrico àquele realizado pelo menino. No texto "Algumas conseqüências psíquicas da diferença anatômica entre os sexos", Freud (1925/1976), porém, se abstém de insistir nessa simetria, pois verifica que a diferença anatômica repercute no impacto psíquico do complexo de 
castração. As meninas rapidamente ajuízam sobre o que viram. "Ela o viu, sabe que não o tem e quer tê-lo" (Freud, 1925/1976, p.134). Os efeitos do complexo de castração se traduzem em efeitos que se aglutinam em três direções possíveis. As meninas caem sob o golpe da inveja do pênis e abandonam sua atividade fálica, podendo o resultado final levar a uma repulsão geral à sexualidade ou, então, a totalidade de sua sexualidade vem a ser drenada na formação reativa do complexo de masculinidade. A terceira via, a que conduz à feminilidade normal, conduz à assunção, pela menina, de sua castração, e na esperança de obter o falo que lhe falta do pai sob a forma do objeto criança. A criança do sexo feminino se introduz na simbólica do dom como aquela que não possui o falo e entra no complexo de Édipo, na medida em que faliciza a situação.

Nesse mesmo artigo, Freud se depara com o problema da resolução do Édipo, pois falta à menina a influência da ameaça de castração, que no menino põe fim às suas aspirações incestuosas. Na menina, a chegada à posição edipiana positiva é como um ponto de repouso, já que a tomada do pai como objeto de amor não a conduz a abandonar por completo as antigas aspirações e desejos em relação ao objeto materno. O complexo de Édipo é, no caso da menina, uma formação secundária. A resolução incerta que marca a sua saída do conflito edípico reflete-se, tanto na formação do superego, que nunca alcança a mesma severidade como a que se verifica na economia psíquica do menino, como na condição feminina como ser social. Ao lado da dependência feminina em relação ao temor da perda de amor, Freud (1925/1976) estima que a condição libidinal feminina é menos afeita às realizações da sublimação no campo da cultura. Há um privilégio das satisfações vinculadas à relação com o parceiro sexual e com aqueles que são o produto dessa 
relação, as crianças (filhos). Os vários aspectos repertoriados por Freud no exame dessa questão testemunham os efeitos do difícil caminho a ser percorrido pela mulher em relação à simbolização de sua falta fálica.

Em 1931, Freud retorna à temática das vicissitudes do Édipo na menina à luz de sua história pré-edípica, ressaltando que seu vínculo originário com a mãe é complexo e violento. A simplicidade, inicialmente atribuída à passagem do objeto materno para o paterno, é abandonada, já que essa substituição deixa resíduos que a clínica não desmente. O desenlace, freqüentemente turbulento entre a menina e sua mãe, prolonga-se nas relações amorosas/eróticas na vida adulta de uma mulher, deixando vestígios em seus traços de caráter. A esse respeito, Freud observa a regularidade com que as mulheres repetem com seus parceiros amorosos a batalha travada nos anos de juventude com suas mães. A relação com o objeto paterno que comandou a escolha do parceiro masculino nada mais parece refletir, nesse caso, do que uma transferência da intensa e original ligação com a mãe.

A tarefa da menina no complexo de Édipo é dupla e sem equivalente em relação àquilo que é exigido do menino. A menina deve realizar a substituição do objeto materno pelo paterno e a libido deve deslizar da primeira zona erógena, o clitóris, para a vagina (Freud, 1931/1974). No entanto, a insatisfação da menina nesse processo é recolhida nas severas censuras que ela dirige à sua mãe, pois ela a acusa de trazê-la ao mundo desprovida de um órgão tão precioso, isto é, por tê-la trazido ao mundo como uma mulher, castrada. As tempestades que se seguem a essa censura revelam a presença de um ódio que é desconhecido no terreno da relação do menino com o objeto materno. Chatel (1995) destaca que esse ódio 
violento da filha em relação à mãe conduz aos efeitos da devastação, pois a menina espera receber mais pelo lado de sua mãe do que pelo lado de seu pai, subsistência para seu ser de mulher.

\begin{abstract}
A devastação seria a experiência dolorosa devida à inexpugnável reprovação que uma filha dirige à sua mãe, e que esta última não pode acalmar. Proponho encarar a devastação como sendo a prova mesmo do inevitável confronto com essa impossibilidade entre elas. [...] é o impossível prolongamento de uma na outra, a impossível partilha da experiência feminina; é também a impossibilidade de se conhecer inteiramente [...] (Chatel, 1995, p. 48).
\end{abstract}

O desenvolvimento em direção à feminilidade normal arrasta os fenômenos residuais da pré-história do período masculino inicial, já que "o anseio com o qual a menina se volta para o pai é exatamente o desejo originário do pênis do qual a mãe a frustrou e que ela espera agora obter do pai" (Freud, 1933b/1976, p.157). As elaborações freudianas insistem, entretanto, na solução do desejo do filho como caminho de certo modo obrigatório para a realização da mulher que passa a coincidir com o tornar-se mãe. A identificação com a mãe pré-edípica, segundo Freud (1933b/1976, p.164), provê a mulher com aquilo que incita o desejo do parceiro masculino, na medida em que '[...] a ligação edipiana deste à sua mãe transfigura a atração da mulher em paixão. No entanto, com tanta freqüência sucede que apenas o filho obtém aquilo que o homem esperava". A clínica leva Freud a encontrar o logro da solução do desejo do filho no destino da realização da mulher como ser sexuado. O tornar-se mulher se confunde com o tornar-se mãe e o equívoco dessa equivalência retorna no recobrimento do casal homem-mulher pela relação mãe-filho. A criança-filho vem aí cumprir a função de realizar o impossível, a relação sexual. 
André (1987) discute que o limite da posição freudiana é atribuir ao filho o papel de significante da identidade feminina, fazendo consistir uma essência feminina onde, na verdade, há uma lacuna no simbólico. O autor aponta que a metáfora paterna não se impõe por inteiro no destino da menina, na medida em que a introdução do sujeito à lei do falo re-sublinha a exclusão do ser feminino do campo da representação.

Nessa mesma linha de argumentação o autor afirma que a eficácia, alegada por Freud, da identificação da menina à mãe não inclui a impossibilidade de ela encontrar junto à mãe um traço simbólico que dê sustentação a uma identidade feminina. A única referência que a menina encontra junto à mãe é a referência ao falo, o qual a mãe não possui, assim como ela. A falta materna é vivida pela menina como uma dupla decepção: há a falta do significante de uma identidade feminina e há a falta do falo. O significante não recobre o real, ele cria o furo, recorta suas bordas e o relança. "[...] o falo não camufla o furo, fá-lo surgir mais além" (André, 1987, p. 27).

Soler (2005) examina as teses freudianas e conclui que a construção do Édipo fornece uma resposta satisfatória de como se produz um homem, mas deixa intacta a questão da problemática da mulher, na medida em que a lei da castração não regula todo o campo do gozo. Segundo a autora, a contribuição da obra de Lacan, nesse ponto, consiste no movimento de logicizar o inconsciente, demarcando a possibilidade de um além do Édipo que contempla a dimensão de um gozo que excede a ordem do gozo fálico, um gozo Outro que se situa fora do campo 
do sentido. A mulher encontra-se concernida, mas não-toda, à ordem fálica. A Mulher seria, então, um dos nomes desse gozo Outro, do real.

A psicanalista ainda destaca que Lacan, sem objetar ao falicismo no inconsciente, explora a dialética do falo pelo viés do ser, possibilitando articular com mais rigor a inscrição da mulher no par sexual enquanto ocupando o lugar de objeto causa de desejo para o homem. "No amor, graças ao desejo do parceiro, a falta se converte num efeito, por ser quase compensatória: a mulher se transforma no que não tem" (Soler, 2005, p.28). No entanto, como a mulher não se encontra concernida por inteiro na lei da castração, temos como conseqüência que a dimensão do gozo que se encontra aberto a ela não se restringe à satisfação usufruída na relação de amor com o parceiro masculino, nem tão pouco à satisfação que ela pode extrair com o produto dessa relação, o filho.

Os elementos apresentados nos reportam ao fato de que a dimensão do materno se articula a do feminino sem recobri-lo no destino da mulher como ser sexuado, uma vez que a criança preenche e divide a mãe. Lajonquière (2005) aponta que a criança enquanto fruto do mal-entendido, do (des)encontro entre uma mulher e um homem, porta para a mãe o mistério relativo ao enigma da diferença entre a mãe e a mulher. O estatuto do amor da mãe em relação a seu filho está marcado, portanto pela ultrapassagem da mãe pela mulher quando esta "[...] não está dissuadida de encontrar seu desejo no corpo de um homem" (Miller, 1996, p.7). A incidência da função do pai no desejo da mãe é uma condição necessária para permitir ao sujeito em constituição um acesso normativo a sua posição sexual, mas isso não é tudo (Miller, 1996). 
Se, por um lado, é o narcisismo materno que fornece para a criança a sustentação e a consistência de uma imagem unificada na qual ela pode se contemplar como uma unidade, por outro lado o atravessamento do materno pelo desejo feminino põe um termo na paixão materna pela criança. Entendemos que é a presença da mulher na mãe a dimensão que funda e que também limita o amor da mãe. É a presença do desejo feminino na mãe que a torna não-toda para seu filho, possibilitando que haja separação.

Bergès e Balbo (2002) contribuem na reflexão sobre a articulação entre o feminino e o materno apontando que é desde sua condição de sujeito dividido que a mãe faz uma hipótese de saber em seu filho e que o conduz a aceder ao campo do simbólico. O amor da mãe sustentará o percurso do infans na medida em que esse amor não é apenas especular, pois a mãe não sabe tudo sobre seu filho. É esse não-saber da mãe que torna esse amor operante e estruturante.

O jogo de posições que se estabelece entre a mãe e a criança vem a ser deflagrado pela condição enigmática do recém-nascido para a mãe, já que não há uma correspondência unívoca entre o que a mãe deseja e aquilo que a criança lhe demanda, isto é, o exercício da função da mãe se desenrola num outro plano que não é o de uma complementaridade natural com as necessidades da criança. No nascimento prematuro, a potência dessa dimensão enigmática se redobra pelas condições que acompanham esses nascimentos que adiam, limitam, e transtornam o encontro da criança com a mãe. Os fragmentos da falas dos pais dos bebês prétermo serão trazidos para avançarmos em nossas elaborações. Vejamos agora como a inscrição da mãe como Outro primordial para o recém-nascido é o ponto de 
partida que nos permite acompanhar os diferentes planos em que se desdobra sua função junto ao infans.

\section{O BEBÊ E O OUTRO PRIMORDIAL}

Para Freud, o bebê humano é um ser inacabado, um prematuro, pois ao nascer ele não é capaz de realizar a ação específica que permite o cancelamento das excitações que transbordam seu organismo quando são deflagradas as exigências de suas necessidades vitais. No Projeto para uma Psicologia Científica, Freud (1895/1974) vai apontar que é nessa falha que se introduz a função do próximo prestativo (Nebenmensch), o qual vem trabalhar o mal estar que se apossa do organismo do bebê. A atenção desse semelhante para a condição de desamparo da cria humana é atraída pela expressão de suas emoções, através do grito e das inervações musculares que desempenham, em tal circunstância, a importante função de comunicação.

O atraso de maturação do neonato se traduz pela presença de vestígios humorais do organismo materno e pelo inacabamento anatômico do sistema piramidal. Os embriologistas empregam o termo fetalização para designar 0 inacabamento neurológico que é caracterizado pelo déficit de mielinização no início da vida. Lacan (1998) considerou que o contraste entre a condição desse inacabamento neurológico e as capacidades perceptivas precoces já presentes no recém-nascido (a criança reconhece já um rosto humano em torno do décimo dia de vida) é responsável pelo valor de antecipação funcional que essas capacidades perceptivas vão adquirir nos primórdios da vida humana, no laço com o semelhante. 
Essa hiância vai ser solidária da potencialidade de uma instauração psíquica que vai permitir a constituição de uma subjetividade.

A experiência de satisfação alimentar do bebê é o modelo tomado para examinar, em toda a sua extensão, as conseqüências do encontro inaugural do bebê com o semelhante. Freud (1895/1987) estima que ocorrem três conseqüências importantes como resultado da totalidade da experiência de satisfação: a eliminação do estado de urgência que causou o desprazer, a inscrição do traço mnêmico correspondente à percepção do objeto (o seio), e a inscrição de um traço correspondente à descarga do movimento reflexo liberado pela ação específica. Quando o bebê se encontrar novamente tomado pelo estado de urgência haverá, graças à associação do traço mnêmico do objeto com o registro mnêmico da excitação da necessidade, o desencadeamento de um impulso psíquico que tende a reinvestir esse traço mnêmico que conduzirá à realização alucinatória do desejo. A imagem mnêmica funcionará para o bebê como uma representação antecipada da satisfação e a reaparição do estado de urgência promoverá o investimento nessa imagem, e este investimento será a realização do desejo. Notemos, que a realização de desejo encontra-se, para Freud, inteiramente concernida à realidade psíquica. Não há coincidência ente o objeto alucinado e o objeto real.

Cabe observar, que as manifestações dos imperativos orgânicos que se traduzem por estados de tensão no corpo do bebê são tomados como mensagens pela mãe ou seu substituto, os quais se posicionam como destinatários privilegiados desse apelo junto ao recém-nascido. O bebê, entretanto, não mobiliza de imediato suas manifestações corporais de maneira intencional, mas, a partir do momento em 
que o outro transforma seu grito em apelo, a criança é introduzida no universo de discurso desse outro.

Deste ponto de vista, o outro que inscreve a criança neste referente simbólico investe-se por sua vez, junto à criança, como um outro privilegiado: o Outro. A mãe, elevada assim à posição do Outro para a criança, desta mesma feita assujeita-a ao universo de seus próprios significantes, visto que mobiliza, através do oferecimento do objeto alimentar, uma resposta ao que ela mesma previamente interpretou como uma suposta demanda (manifestações corporais). Ora, de uma certa maneira, não se pode deixar de tomar esta demanda suposta como projeção do desejo do Outro (Dor, 1989, p.144).

A introdução do Outro no circuito da experiência de satisfação desdobra o que a princípio parecia apenas a satisfação de uma necessidade, pois o repouso orgânico da criança, que se segue ao apaziguamento da necessidade, adquire novamente para a mãe valor de mensagem, que ela recebe como testemunho de reconhecimento. Ela dá extensão à experiência oferecendo gestos e palavras que se introduzem como um a mais de repouso para a criança. A experiência de satisfação transborda a satisfação da necessidade visada, pois ela contempla a criança com um a mais de gozo que ela não demandou nem esperou.

A repetição da experiência de satisfação vai requerer a articulação da demanda pela criança o que, por sua vez, vai implicá-la na dimensão de uma perda, na medida em que a demanda, ao se articular pelo significante, vai gerar uma não coincidência, um intervalo, entre aquilo que é demandado pelo sujeito e a resposta do Outro, ou seja, a cada demanda vai se ratificar o impossível re-encontro com o primeiro gozo experimentado com esse Outro. Há um movimento do aparelho psíquico em tentar obter a coincidência entre o traço mnêmico do objeto e a excitação atual, aquilo que o texto de Freud designa como identidade de percepção. 
Haverá, nesse caso, necessariamente, decepção e fracasso, pois há diferença entre a satisfação esperada e aquela obtida.

Este Outro que fez a criança gozar, [...] permanece inacessível e perdido enquanto tal, devido à cisão introduzida pela demanda. Assim, esse Outro torna-se Coisa - das Ding - da qual a criança deseja o desejo, mas que nenhuma de suas demandas, nas quais se apóie esse desejo, jamais poderá significar adequadamente (Dor, 1989, p.146).

Para Lacan (1988), sem essa alucinação primitiva não haveria possibilidade de ordenação do mundo humano, pois ela implica o sujeito numa busca, certamente impossível, porém indispensável à organização do mundo do desejo, pois a cada demanda se escava o vazio do objeto perdido, remetendo o sujeito à nãocoincidência do seu ser com o objeto. O encontro do objeto é sempre um reencontro, já que a satisfação atual é sempre buscada na referência do objeto que proporcionou a satisfação passada. No entanto, as coordenadas de prazer do Nebenmensch funcionarão como referência simbólica para o sujeito nessa busca. A experiência de satisfação deixa um resto não assimilável, das Ding, que se subtrai ao recobrimento pelo simbólico, permanecendo como estranho, demarcação de um primeiro exterior, contudo íntimo ao sujeito.

Aí, a repetição busca o reencontro de das Ding, a revelação do real pelo significante, fazendo-se ponto inicial da organização do mundo no psiquismo, a partir deste elemento originalmente isolado pelo sujeito como estranho, primeiro exterior, fora-do-significado, portanto insubstituível. [...]. A perda de das Ding funda a possibilidade do aparelho psíquico, remete ao impensável da origem e à impossibilidade de o gozo se dizer (Vorcaro, 1997, p.88).

A função humanizante da experiência de satisfação nos leva a considerar que o outro humano tem um papel capital no alicerce das primeiras ligações psíquicas, no estabelecimento das Bahnungen (facilitações), que constituirão o leito necessário 
dos processos de pensamento e julgamento. Coriat (1997) assinala que a noção de Bahnung (facilitação) é essencial para pensarmos os caminhos pelos quais o banho de linguagem que acolhe o bebê chega a infiltrar-se no corpo orgânico real. Para a autora, os avanços da neurobiologia apontam que as condições de uso psíquico do aparelho neuronal não são indiferentes à qualidade do laço do neonato com o Outro, pois a capacidade de registro dos estímulos não obedece apenas à informação congênita, mas essa capacidade revela ser modulada "[...] em função do uso que dela se faça, fundamentalmente nos primeiros meses de vida" (Coriat, 1997, p.269).

A inscrição das sucessivas experiências, tanto de prazer como de dor do infans, vai compor o primeiro sistema de marcas sincrônicas sobre a qual operarão as sucessivas transcrições que organizarão as diferentes tópicas do psiquismo, tal como Freud (1896) formalizou na Carta $52^{1}$. Sem o estabelecimento do sistema Wz (signos de percepção) que registra o que incidiu como marca de prazer ou dor no sistema W (percepção), não há condições de constituição das Bahnungen.

Freud (1896/1987), na Carta 52, concebe o mecanismo psíquico como algo constituído por estratificações que, de tempos em tempos, sofrem uma retranscrição. "[...] o que há de essencialmente novo a respeito de minha teoria é a tese de que a memória não se faz presente de uma só vez, mas se desdobra em vários tempos; que ela é registrada em diferentes espécies de signos" (Freud, 1896/1987, p. 254). O sistema Wz (Wahrnehmungszeichen - signos de percepção) é o registro das percepções que se dispõe por simultaneidade. É inacessível à

\footnotetext{
${ }^{1}$ Correspondência com Fliess, de 06-12-1896.
} 
consciência, e é sobre ele que incidirá a primeira operação de transcrição, recalcamento, que fundará o estrato seguinte, o Ub (Unbewusstsein), o inconsciente.

O exemplo trabalhado por Coriat para acompanhar os efeitos dessa operação de inscrição e apagamento do traço é o reflexo inato no bebê que privilegia, como objeto de visão, o olhar interessado de um outro ser humano em direção a ele. Spitz (1975) já havia observado esse interesse no recém-nascido pelo que ele chama gestalt-sinal composta pelo conjunto frente-olhos-nariz que se destaca da visão frontal do rosto humano. A presença desse precursor, para o autor, atesta que um elemento se destaca das coisas caóticas que compõem o mundo do bebê. Sem demora, essa configuração deixa de se fazer constar como um sinal, pois esse precursor encontra-se intimamente associado ao rosto de sua mãe, que é quem o alimenta, o protege e the fornece o sentido de segurança, revelando o estabelecimento dos primeiros indícios de memória. A mãe é a parceira humana da criança, pois interpreta suas percepções e suas ações. Esse precursor indica que um processo de pensamento se encontra em curso para o bebê, além de apontar nele um deslocamento do narcisismo primário para um investimento numa relação de objeto, ainda que se trate, nesse instante, de seus primórdios, já que não se pode ainda falar de um ego estruturado no bebê.

Quando o bebê não encontra esse olhar interessado, depois de alguns dias do nascimento, ele corre o risco de perder todo o interesse pelo assunto, o que implica que ele não buscará esse olhar. Estima-se, que essa perda repercutirá na manifestação do sorriso social por volta dos dois ou três meses que, como sabemos, 
é considerado por Spitz um organizador ${ }^{2}$ que celebra um progresso psíquico da criança. Consideramos que esse organizador, a manifestação do sorriso social, atesta que para o bebê houve encontro, ou seja, que se produziu um laço, que se iniciou uma história, que o Outro simbólico agiu, que houve antecipação, enfim que primeiro a mãe lhe sorriu.

A autora traduz a conseqüência desse não-olhar da mãe para o bebê como sendo equivalente à ausência de inscrição do traço unário que corresponde ao objeto perdido da pulsão escópica, na medida em que não se realizou nenhuma experiência de satisfação no nível da visão. A constatação da importância radical dos efeitos da posição do Outro no laço com a criança leva a autora a declarar que o Outro escreve no corpo do infans.

[...] se as primeiras Bahnungen (no nível da inervação dos axônios) são estabelecidas em função de seu uso; e se este uso está determinado pela aparição de objetos interessantes ao bebê; e se, como sabemos, os objetos são apresentados ao infans pelo Outro; então o Outro participa diretamente (durante o ato mesmo da escrituração) na construção do papel (Coriat, 1997, p.271).

O papel é, nesse caso, metáfora da superfície corporal, sobre a qual se inscrevem os efeitos do significante que vão recortar as bordas através das quais se realizam as trocas, a satisfação pulsional, entre o bebê e o Outro, pela demarcação do vazio do objeto. A experiência de Coriat no trabalho com crianças com comprometimento do desenvolvimento (portadoras de déficit orgânico) a leva a questionar em que medida um certo olhar destinado à criança pelos pais não imobiliza os processos que permitem encadear na criança a constituição do sujeito

\footnotetext{
2 "Fatores organizadores" é um termo tomado da embriologia que designa certas estruturas que se desenvolvem em um determinado ponto onde se unem diversas linhas de desenvolvimento.
} 
do desejo. O déficit orgânico tem o papel de um limite real do organismo, porém a adesão dos pais ao discurso médico leva a que a criança se perca no olhar do técnico. Nesse sentido o papel como metáfora da superfície corporal, enquanto lugar em que se inscreve a incidência do significante, não nos parece induzir a uma concepção do bebê como uma folha em branco. Há, do lado do bebê, a dimensão de seu real orgânico que age como limite à permeabilidade ao significante. Por sua vez, este limite pode ser interpretado pelos pais como um ponto intransponível a todo e qualquer investimento de desejo ou à suposição de saber nessa criança.

Há, nesse caso, um trabalho de escuta a ser realizado com os pais, a fim de que eles possam declinar de sua identificação ao saber médico que obstaculiza toda possibilidade de encadear a criança nos significantes parentais através dos quais há humanização pelo desejo.

Como manter uma circulação no Simbólico quando há um Real que irrompe com sua possibilidade absoluta, cortando toda significação ou ressignificação. Como fazer para que aquilo que lemos na demanda de tratamento possa ser desenvolvido. Porque nós lemos neste pedido dos pacientes a dupla presença de uma demanda que, por um lado, nos solicita reparação efetiva daquilo que está estragado no organismo da criança, o que faz com que não funcione; e, por outro, a demanda de que algo de seu desejo de filho, neste bebê deformado que acaba de nascer, possa circular [...] (Jerusalinsky et als, 1989, p. 15).

Consideramos que as questões destacadas por Coriat em relação às dificuldades encontradas na clínica com as crianças portadoras de déficits orgânicos são pertinentes para a reflexão sobre os obstáculos encontrados pelos pais na clínica do bebê pré-termo, uma vez que as incertezas em relação ao futuro de suas crianças podem não autorizar os pais a extrair seu bebê da posição de objeto do discurso médico. Na clínica do bebê pré-termo os efeitos do diagnóstico, assim 
como a condição de risco em que se encontram essas crianças, representam, às vezes, uma ameaça à instalação de um olhar que permita aos pais ver além da dimensão de um organismo em risco ou a reparar. O organismo só encontra um corpo se a linguagem lhe oferece um, ou seja, se os pais, como representantes do Outro, puderem antecipar na sua criança o vir a ser do sujeito.

Vimos que a mãe, ao se dispor como interlocutor privilegiado de seu bebê, acolhendo seu grito como apelo, o provê com as condições de realizar as identificações que vão inscreve-lo em relação ao desejo que o antecedeu. Os seus cuidados, por portarem a marca de um interesse particularizado, um desejo nãoanônimo (grifo nosso), vão permitir que esse sujeito se encadeie nos significantes que presidiram sua chegada ao mundo, ou seja, vão possibilitar que ele se situe numa história.

[...] para a mamãe que ouve seu recém-nascido gritar, aquilo não é, de forma alguma um ruído, uma simples descarga; é seu bebê que a chama, ele Ihe fala e ela responde: "estou aqui". E desde esse instante, que chamamos de encontro inaugural, esse grito não é mais um ruído, é um apelo, e a partir daí, antes de qualquer linguagem propriamente dita, o bebê fala, o bebê é promovido ao estatuto de sujeito falante (Crespin, 2004, p.26).

\section{O AMOR É A CICATRIZ DO LAÇO PRIMORDIAL COM A MÃE}

No seminário 4, Lacan (1995) vai apontar que tudo aquilo que se refere à dialética mãe-criança deve partir da seguinte estrutura: mãe-criança-falo. Essa estrutura já coloca, de saída, que a criança nunca está sozinha com sua mãe, pois do lado da mãe há a exigência do falo. "A criança, como real, assume para a mãe a 
função simbólica de sua necessidade imaginária - os três termos estão aí" (Lacan, 1995, p.71).

Vimos que a impotência do neonato tem efeito de convocação à mãe que acolhe as manifestações de seu mal-estar como mensagens que ela encadeia a seus próprios significantes, dos quais se vale, para interpretar toda sorte de sinais emitidos pelo bebê: choro, manifestações corporais, sua quietude, seus barulhos, seus primeiros balbucios e vocalizações, etc. A mãe toma o organismo vivo como um corpo que ela passa a soletrar. Esse organismo, a princípio comandado pelo ritmo dos estados fisiológicos, vai se dobrando aos efeitos do discurso materno, de modo que uma outra ordem aí se instaurará: um corpo marcado, atravessado por uma textualidade.

No entanto, como bem assinala Vorcaro (2003, p. 209), falar de corpo nesse momento implica em considerá-lo pelo ângulo do agente materno: "O corpo do bebê é, pois, o território do Outro materno, território demarcado, esquadrinhado, cujas funções se constituem e se determinam pela economia do funcionamento maternante". O ritmo dos cuidados que a mãe dispensa ao bebê, proporcionando a experiência de satisfação, permite a ele usufruir uma condição parasitária em relação ao funcionamento maternante, e de completa alienação em relação aos objetos que lhe são oferecidos para sua satisfação. Nesse momento, o bebê apenas registra, passivamente, a alternância dos estados de tensão e de apaziguamento, pois "neste nível, a descontinuidade faz alternância circular, meramente recíproca" (Vorcaro, 1997, p.75). A presença se recorta sobre o fundo da ausência e a ausência é segurança da presença. 
Lacan (1995) vai afirmar que, mesmo antes de haver distinção entre eu e nãoeu, a criança testemunha os efeitos de sua captura na ordem simbólica. Quando a alternância presença-ausência é rompida, ou seja, quando um de seus termos não comparece no lugar esperado, quando há incidência do real na estrutura mínima significante, o grito da criança vai se oferecer no lugar do termo ausente. É no nível do apelo que a criança articula os efeitos de sua inclusão no simbólico. Lacan (1995) afirma que, nesse tempo da estruturação, aquilo que a mãe assegura para o infans é a alternância da presença-ausência. A mãe é simbólica e os objetos são reais, ou seja, são equivalentes em relação à satisfação, pois eles não estão referidos ainda à instância da falta.

\begin{abstract}
A criança se situa, portanto, entre a noção de uma agente, que já participa da ordem simbolicidade, e o par de opostos presençaausência, a conotação mais-menos que nos dá o primeiro elemento de uma ordem simbólica. Sem dúvida, este elemento não basta por si só para constituí-la, já que é necessário, em seguida, uma série, agrupada como tal, mas já há virtualmente na oposição mais e menos, presença e ausência, a origem, o nascimento, a possibilidade, a condição fundamental de uma ordem simbólica (Lacan, 1995, p.68).
\end{abstract}

Vorcaro (1997) acrescenta que, no momento em que há incidência do real na articulação significante primitiva, a coisa é desconectada do grito, na medida em que o grito é elevado à condição de apelo pelo agente materno. A autora afirma que isso que se separa do infans pelo grito passa pelo corpo, é referência invocante, resto de um objeto indizível. "O grito incide como urgência do retorno à anterioridade, busca de apagamento da falta. O apelo é dissimétrico à falta; a resposta do agente materno é dissimétrica ao apelo. Um intervalo sustenta a margem do recobrimento que nada reverte ou anula" (Vorcaro, 1997, p.79). 
Nesse ponto, a dialética entre mãe-criança se complexifica, pois a criança é intimada a operar a substituição significante. A mãe é realizada como potência para a criança, pois é ela que responde a seu critério às demandas da criança. É dela que dependem os objetos de que necessita a criança e esses adquirem uma outra função do ponto de vista da satisfação. Os objetos tornam-se, então, dons dessa potência, dom de amor da mãe.

A imaginarização do agente materno é solidária à tomada de um objeto qualquer como possibilidade significante da coisa, posto que o significante - que não satisfaz - é significante de que sua substituição não basta, sustentando a insaciedade fundamental em torno da qual circula a pulsão. É a mãe que é desejada, quando, diante de sua revogação a criança demanda, referenciando-a (Vorcaro, 1997, p. 93).

A falta ressentida pela criança, quando um dos termos da cadeia significante não comparece no lugar esperado, situa retroativamente a mãe como agente da frustração. A abertura para uma dialética que vai incluir uma diversificação dos objetos do mundo humano está diretamente concernida à realização da mãe como potência. Lacan (1995) afirma que os objetos passam a possuir uma dupla propriedade: são objetos de satisfação e signos do dom de amor da mãe. A frustração $^{3}$ é sempre a frustração de um dom de amor que o sujeito esperava receber do outro. "O que está em jogo é menos o objeto que o amor de quem lhes pode fazer este dom. O objeto da frustração é menos o objeto que o dom" (Lacan, 1995, p.101).

\footnotetext{
${ }^{3}$ Lacan, no seminário 4 , A relação de objeto e as estruturas freudianas, define a frustração como dano imaginário e o objeto dessa operação como real. 0 autor afirma que só há frustração quando o objeto reivindicado entra na área narcísica das pertinências do sujeito.
} 
A dimensão do dom implica a existência de uma cadeia simbólica que ultrapassa o sujeito, na medida em que o dom oferecido numa certa gratuidade está encadeado a um ciclo de dons mais complexo. A falta ressentida pela criança é significada como um dano imaginário, e o objeto oferecido ou recusado ao apelo pelo Outro Onipotente que se torna a mãe passa a ser conotado pelo signo da presença-ausência. "Digo, que toda satisfação posta em causa na frustração advém sobre o fundo do caráter fundamentalmente decepcionante da ordem simbólica. A satisfação aqui não passa de substituto, compensação" (Lacan, 1995, p. 186). Assim, aquilo que é visado para além daquilo que a criança demanda é o dom do amor do Outro materno, dom de uma presença.

Toda a experiência da criança junto à mãe está referida à condição de que ela é um objeto de amor para sua mãe. À situação em que a criança é satisfeita em suas necessidades pelos cuidados maternos é necessário incluir que há um a mais nessa satisfação, que se origina do fato de que ela, a criança, é um objeto satisfatório para o Outro (Crespin, 2004). A criança dá prazer e satisfaz a mãe.

O trajeto que a criança realizará junto ao Outro pelo qual se cumprirá o seu devir como sujeito está dado de saída pela posição simbólica da criança em relação à falta materna que a refere ao falo imaginário. A criança está colocada, portanto, desde o início, numa relação ao desejo da mãe, desejo que não é possível satisfazer, mas a criança se engaja numa verdadeira aventura para tapeá-lo, oferecendo-se como aquilo que ela não é. A identificação fálica que sustenta o engodo amoroso, condição para que a criança chegue a perceber que algo pode 
faltar, implica, como tal, o desdobramento da dimensão do imaginário a partir da identificação do espelho.

É na medida em que o imaginário entra em jogo que, sobre os fundamentos das duas primeiras relações simbólicas entre o objeto e a mãe da criança, pode aparecer que, tanto à mãe quanto a ela, algo pode faltar imaginariamente. É na relação especular que o sujeito tem a experiência e a apreensão de uma falta possível, de que alguma coisa mais além pode existir, alguma coisa que é uma falta (Lacan, 1995, p. 179).

Vejamos como a hipótese da identificação transitivista desenvolvida por Bergès e Balbo permite acompanhar os momentos preliminares da experiência especular e da dialética de amor no laço precoce do infans com a mãe. Veremos como na operação do transitivismo materno o olhar, a voz, o corpo e a fala materna vêm oferecer para o infans os alicerces que sustentam sua identificação ao espelho.

\section{O AMOR DA MÃE SEGUNDO A ÓTICA DO TRANSITVISMO}

No livro Jogo de posições da mãe e da criança, Bergès e Balbo definem o transitivismo como um processo em que a mãe obriga a criança a fazer a prova dos afetos em seu corpo, o qual ela primeiro antecipou e experienciou em seu lugar. $\mathrm{O}$ discurso transitivista materno implica na antecipação, pela mãe, de um saber a ler no corpo de seu filho. Ela se dirige àquilo que, do lado dele, se encontra como virtualidade. Qual é o estatuto da demanda que a mãe supõe que sua criança lhe endereça? É o de que ela, a mãe, leia nela, criança, o saber que já está lá, "[...] saber ao qual ela vai identificar-se, tomando posse assim, simbolicamente, de um bem que ela já possui realmente" (Bergès e Balbo, 2002, p. 12). 
O transitivismo materno opera uma forçagem que, no entanto, difere do traumatismo disruptivo, pois esse golpe de força é objeto de uma elaboração simbólica pela mãe. Os autores insistem sobre esse ponto, pois se nada viesse a incidir sobre o real, como esperar que algum enodamento pudesse ocorrer entre o imaginário, o simbólico e o real. "[...] o que se tornaria uma criança que nada viesse constranger! [...]" (Bergès e Balbo, 2002, p. 11). Quando houve fracasso do transitivismo materno é a relação da criança com o corpo que fica em sofrimento, pois, justamente, Ihe faltou um outro que pudesse operar essa forçagem e que franqueasse a ela um acesso ao simbólico. A freqüente insensibilidade à dor no psicótico poderia bem dizer sobre esse fracasso. Já vimos que a experiência de satisfação realizada no laço com o semelhante deixa como saldo a inscrição de um complexo de traços mnêmicos que vão ser reinvestidos quando re-surge a exigência pulsional. Freud (1895/1987), postula o mesmo caminho no que respeita à experiência da dor, pois só haverá inscrição psíquica da dor quando esta tiver sofrido a mediação simbólica pela relação com o semelhante.

O transitivismo materno não é apenas o que a mãe experiencia se colocando no lugar da criança, mas é todo o processo que ela coloca em marcha quando faz uma hipótese de saber em seu filho. Esse processo implica uma convocação da criança a se introduzir no campo da fala e da linguagem. É importante observar que essa operação passa necessariamente pelo corpo, mas o corpo a ser entendido como receptáculo. Vejamos o que os autores nos dizem sobre essa noção:

O corpo é aqui esse lugar de receptação através do qual o mundo toma forma e consistência para a criança. Aprende-se que esse acesso ao simbólico, que representa a identificação da criança ao discurso da mãe, concerne ao corpo, na medida em que não é 
somente corpo imaginário, mas também corpo de linguagem, de significantes e letras (Bergès e Balbo, 2002, p. 10).

Leite (2006), por sua vez, aponta que a noção de corpo como receptáculo a partir do discurso analítico coloca em primeiro plano a noção de corpo como superfície produzida pelo corte do significante. O corpo, portanto, é, antes de tudo, uma dimensão topológica. A autora afirma que o corpo, tomado como receptáculo, já implica um funcionamento do significante sobre o real do organismo, e que esse funcionamento é condição para que a criança venha a poder fazer a teoria sexual infantil.

O transitivismo é solidário de um funcionamento que se subtrai da bipolaridade sujeito-objeto, visto que a referência ao discurso permite intercalar entre o sujeito e o objeto a dimensão do Outro. A referência à demanda formulada pelo discurso da mãe concernente à hipótese de saber que ela faz em seu filho introduz a dimensão desse terceiro. Vejamos como essa dimensão pode ser captada nos três momentos nos quais se decanta essa operação segundo Bergès e Balbo (2002 p. 27):

- Num primeiro momento, quando o filho grita, sua mãe por amor lhe dá a fome, a sede, ou pensa nos cuidados.

- Num segundo tempo ela o nutre, dá-lhe a água, cuida dele.

- No terceiro tempo haverá a verificação da hipótese que ela havia feito em seu filho. 
Haverá entre o primeiro e o terceiro tempo, necessariamente, uma defasagem, já que não há concordância completa entre o que a mãe supôs na criança e aquilo que a criança experienciou em seu corpo. Vale dizer, que esse intervalo é o que permite que as atividades da criança sejam tomadas como causa do relançamento da demanda, pois, caso contrário, haveria apenas autorelançamento da demanda materna projetada em seu filho, o que seria extremamente corrosivo do ponto de vista da constituição do sujeito. Vemos, então, a importância da distinção entre a necessidade, a demanda e o desejo.

As manifestações motoras da criança produzem, por sua vez, uma novidade perceptiva para a mãe, incitando o prolongamento desse circuito, na medida em que ela responde a essa novidade através da interpretação dessa atividade motora, prolongando-a e conduzindo a uma modificação mesma da demanda. "A atividade do filho é a colocação em ato da hipótese de saber que sua mãe supõe nele, e ela é libidinizada na medida em que está enlaçada ao desejo da mãe, que a relança sem cessar" (Bergès e Balbo, 2002, p. 34).

O relançamento da demanda implica, pelo lado da mãe, que ela decline de um lugar de tudo saber sobre a criança para que a dimensão do impossível, em torno do qual se articula a demanda, seja preservado. Quando a resposta da mãe se pretende totalizadora, o circuito da demanda se degrada e sufoca o pulsional na criança, pois um objeto jamais pode responder a uma demanda. Nesse caso, a criança será dividida, mas por um saber que será propriedade única de sua mãe. Os autores vêm, no rebatimento da demanda sobre a necessidade, uma incompetência da mãe em transitivar, que vai gerar como conseqüência uma degradação dos 
processos de pensamento na criança, da estruturação do corpo e das condições de articulação da demanda. Os autores ilustram tal degradação indicando o que ocorre, por exemplo, ao nível da perturbação da estruturação da atividade oral nas patologias graves: "[...] o autista que deixa escorrer sua baba: ele não pode exprimila, visto que ela está colada, pela sua saliva, à necessidade" (Bergès e Balbo, 2002, p. 37).

Consideramos importante pensar a antecipação do agente materno como um momento lógico primordial que vai inscrever o bebê no campo da palavra e da linguagem, pois sem essa antecipação não há como ocorrer uma abertura da criança para a dimensão do ser e do corpo. O encontro do organismo com o discurso do Outro produz as inscrições significantes que vão delimitar as bordas desse corpo, pois é a partir da defasagem produzida pela demanda que essas bordas vão se dispondo em torno do vazio deixado pelo objeto. É o agente materno que realiza a costura dessas hiâncias que vão estruturar o corpo do bebê. É preciso que primeiro tenha havido antecipação, quer dizer, que a criança tenha ouvido falar de si e é isso que ela vai encontrar na experiência do espelho. "[...] é quando a mãe fala, por seu discurso, ao mesmo tempo de palavra em palavra, e de letra a letra, a mãe esfacela o corpo de seu filho e ao mesmo tempo o reúne, visto que esse corpo vai se sustentar numa certa sintaxe. É essa sintaxe também que a criança reencontra diante do espelho" (Bergès e Balbo, 2004a, p. 155).

Os autores consideram que o movimento de antecipação que é solidário ao exercício da função materna cumpre um importante papel na articulação das precoces experiências do neonato entre a dimensão do escutado e do visto, pois o 
enodamento lógico entre essas duas ordens depende da consistência imaginária fornecida pelo discurso do semelhante. Quando a mediação simbólica da mãe especular é precária o bebê corre o risco de permanecer à deriva do turbilhão do real do escutado. O primado do escutado, do fonema, em relação às manifestações da dimensão do olhar no recém-nascido revela, segundo Bergès e Balbo (2004b) que há precocemente um movimento de buscar a ligação entre a imagem e o som, ou seja, um encadeamento entre a forma visual virtual e o fonema real do escutado. O universo escópico do neonato é, desde o início, perfurado pelo turbilhão do fonema na dimensão do escutado.

Nessa análise, os autores tomam o reflexo buco-lingual de orientação manifestado pelo neonato em torno do segundo mês de vida. Esse reflexo se manifesta por um movimento lateral de cabeça do bebê em direção a pessoa que se aproxima dele quando ele tem fome. O bebê abre a boca e avança os lábios. Tratase de uma resposta a um estímulo exterior em função da percepção interoceptiva de uma pulsão insatisfeita. Observa-se que essa conduta se diversifica e que a criança passa a seguir a fonte de satisfação, a mãe, com os olhos e que seu interesse passa a se dirigir a outros aspectos como, por exemplo, o rosto humano de sua mãe e em outros momentos que não apenas o da alimentação. Bergès e Balbo (2004b) sublinham que há uma busca do recém-nascido de identificar no mesmo espaço o escutado e o visto e que ele fica ansioso quando vê que sua mãe está num lugar e que sua voz provém de outro. Os autores extraem dessa observação um ensinamento importante: o de que há uma ligação lógica entre a oralidade, o escutado e o visto e que no bebê o olho, o ouvido e a boca comportam-se como um único órgão, o orolho. Como sabemos, dentre todos os orifícios do corpo, o ouvido é 
aquele que não se fecha, o escutado confronta o infans com o que lhe é radicalmente Outro. Para os autores, o transbordamento fonemático entalha o real, criando um furo no qual a antecipação visual virtual cria uma borda simbólica. Essa borda simbólica é criada pela fala do outro que confere "[...] o sentido e o imaginário do qual ela se sustenta, pode Ihe dar um limite, conferir-lhe um ritmo, valor de presença ou de ausência em relação a esse contínuo sonoro sem solução de continuidade entre o dentro e o fora" (Bergès e Balbo, 2004b, 133).

A observação de Bergès e Balbo sobre a articulação precoce entre a dimensão da oralidade, do visto e do escutado nos reporta à importância da função do cuidador na clínica do bebê pré-termo, uma vez que esses bebês são extremamente suscetíveis à desorganização fisiológica em razão da imaturidade do desenvolvimento do sistema nervoso central. Atualmente, as estratégias de contenção adotadas pela equipe terapêutica durante a realização dos procedimentos invasivos ou nos momentos da rotina de higiene com o bebê levam em conta a leitura dos sinais emitidos por ele, de modo a respeitar os limites tolerados pela capacidade de seu organismo para gerir esses estímulos. A aceitação ou a intolerância do bebê em relação aos cuidados se traduzem numa diversidade de sinais como, por exemplo, a alteração da freqüência cardíaca, respiratória, na queda de saturação do oxigênio, mudanças na coloração da pele, etc. Já vimos que a tarefa primária do bebê pré-termo é a obtenção da homeostase frente aos diversos estímulos que são lançados nos subsistemas que não estão preparados ainda para essas estimulações. Há uma visão compartilhada pelos especialistas de que tais estímulos estão alterando continuamente para melhor ou para pior a real estrutura do cérebro. A adequação do ambiente da UTI Neonatal é fundamental, pois esse 
ambiente em tudo difere do ambiente intra-uterino, uma vez que ele é repleto de estímulos tais como ruídos e excesso de luminosidade que são adversos à gestão sensorial pelo bebê prematuro. "Os sistemas sensoriais começam a funcionar antes que suas estruturas apresentem maturação completa, e nessa ontogenia existe uma influência bidirecional entre estrutura e função, [...]" (Ministério da Saúde, 2002, p. 120). Nesse caso, cabe ao cuidador do bebê fornecer as ligações psíquicas, isto é, as bordas simbólicas que permitam a ele recuperar o sentido da continuidade de suas vivências corporais. Na rotina das unidades de tratamento intensivo neonatal já se verifica que a fala endereçada ao bebê ou a contenção pelo ato de tocá-lo apropriadamente quando há um acontecimento perturbador provocado pelo início de um procedimento são capazes de conduzi-lo em poucos momentos a uma condição de repouso. Conforme foi também apontado nas observações de Coriat, a realização da experiência de satisfação no laço com o outro constitui o alicerce do processo de pensamento e do corpo, na medida em que se inscreve a defasagem entre o pulsional e o orgânico, já que é em torno do vazio deixado pelo objeto perdido que se estrutura o circuito da pulsão.

Quando a mãe declina da posição de mestre em relação à demanda da criança, ou seja, quando ela não toma por inteiro aquilo que é produzido por ela como idêntico ao falo imaginário, ela permite que a criança possa encontrar uma distância em relação a seu corpo. "Nessa estrutura, que supõe um terceiro termo, é que se exerce a função pela qual existe significante da falta no Outro: ou bem falta do lado do saber, ou bem falta do lado do desejo da mãe" (Bergès e Balbo, 2002, p. 37). Vejamos como essa questão se rearticula pelo caminho das teorias sexuais infantis. 


\section{AMOR MATERNO ECONSTITUIÇÃO DO SUJEITO}

No seminário "A atualidade das teorias sexuais infantis", Bergès e Balbo (2001) partem da grande questão proposta pelo texto freudiano: o que incita o corpo pulsional a fazer uma teoria sexual infantil? Os autores afirmam que essas teorias sexuais infantis passam obrigatoriamente pelo Outro. A criança não está sozinha com seu corpo, ela não faz sua teoria sexual infantil na solidão, pois é necessário que, primeiro, a mãe a autorize a isso, quer dizer, que a mãe consinta em não saber tudo sobre a criança, para que esta possa produzir um pedaço de saber sobre o real que escapa a ela. Lajonquière (2005) aponta que se as coisas não fazem incógnita em nós, não fazem desencontro ou não nos colocam diante de um mistério não nos sentimos concernidos a querer saber mais. Desse modo, segundo o autor, a dimensão do estrangeiro do qual a criança se faz mensageira incita o desejo no adulto de se endereçar a ela. "[...] o estrangeiro é suposto como alguém que tem coisas de Outro mundo para nos contar. Espera que aprenda sua língua para vir saber sobre esse Outro mundo e, assim ficar menos estranho e mais familiar" (Lajonquière, 2005, p. 239).

Se a mãe deseja que a criança cresça e fale é porque ela espera que sua criança Ihe diga porque e como ela esta ali, ou seja, que diga à mãe como ela a concebeu. O porque da mãe não é interrogativo, mas possui o estatuto de causa. Vemos que é a própria questão do enigma da origem que interroga a mãe como ser sexuado na relação com a criança e que a obriga a colocar essa falta de saber como condição de saída a tudo o que vai ocorrer entre elas. 
Há que se considerar que, pelo lado da mãe, existe des-(conhecimento) e é esse des-conhecimento que a leva a delegar um saber a sua criança, ou seja, a realizar uma antecipação de que há um saber em seu filho. A identificação transitivista procede de uma negação do desconhecimento materno do que foi experienciado pelo seu filho. No entanto, o filho pode não ficar satisfeito com a resposta materna, ela pode não corresponder ao real desconhecido de sua necessidade.

\begin{abstract}
Pelo lado do des-(conhecer), ou mesmo, como diria Lacan, se a mãe é capaz de dizer um pouco de bobagens (dé-conner), de uma certa maneira e por sua vez a criança pode conhecer algo. Talvez haja, até mesmo, do lado daquilo que faz buraco para a mãe, daquilo que lhe falta, algo que solicite também a hipótese [...] de que a criança possa the ensinar um pedaço: do contrário, não se sabe como a criança poderia articular algo de um saber que poderia ser seu (Bergès e Balbo, 2001, p.20).
\end{abstract}

Bergès e Balbo (2001) afirmam que, pelo lado da teoria sexual infantil, há uma abertura à identificação naquilo que ela tem de imaginário e simbólico, e essa identificação gira ao redor do amor da mãe. É em torno do amor como objeto a que vem se dispor a língua privada entre mãe e criança, língua da qual a criança precisará se separar para aceder a um gozo fora do corpo da mãe. "A mãe dá a esse amor uma encarnação, a criança que ela acaba de ter" (Bergès e Balbo, 2001, p. 52).

Essa tomada do infans como objeto do amor da mãe é solidária ao comércio sexual, ao corpo a corpo violento, que caracteriza os primeiros tempos da relação da criança com a mãe. Freud (1905/1972), nos "Três ensaios sobre a teoria sexual", já havia assinalado que a dimensão do gozo não é alheia a esse comércio sexual 
precoce que se trama no exercício dos cuidados maternos. O amor materno e a perversão polimorfa infantil caminham juntos.

A relação de uma criança com quem quer que seja responsável por
seu cuidado proporciona-lhe uma fonte infindável de excitação
sexual e de satisfação de suas zonas erógenas. Isto é
especialmente verdadeiro, já que a pessoa que cuida dela, que,
afinal de contas, em geral é sua mãe, olha-a ela mesma com seus
sentimentos que se originam de sua própria vida sexual: ela a
acaricia, beija-a, embala-a e muito claramente a trata como um
substituto de um objeto sexual completo (Freud, 1905/1972, p. 229).

Freud atribui as marcas dessa experiência na criança ao conteúdo da fantasia que freqüentemente as análises desvelam quando mostram que por trás do pai sedutor encontra-se originalmente a mãe. "O papel desempenhado, em seu começo, pela higiene infantil reflete-se na fantasia muito comum que transforma a mãe ou a babá em sedutora" (Freud, 1974/1931, p.267). Para Freud, esse comércio sexual é o caminho obrigatório pelo qual a mãe ensina a seu filho o amor (grifo nosso). Ferenczi (1932), por outro lado, em seu artigo "Confusão de línguas entre os adultos e a criança", argumentou que a criança sofre no encontro com o adulto uma traição, na medida em que ela se depara com a língua da paixão do adulto ali onde ela só dispõe da língua da ternura. No entanto, o exercício da função materna é totalmente solidário a essa "violência" que preside a tomada do corpo do infans pela mãe, na medida em que a mãe como representante inaugural do Outro atualiza esse traumatismo da entrada do sujeito na linguagem, tendo em vista que o significante separa corpo e gozo. A linguagem produz as pulsões e introduz o gozo.

Lacan (1992) aponta, no seminário 17, O Avesso da Psicanálise, esse enodamento original entre a linguagem e o gozo, afirmando que a mulher, na 
condição de mãe, mergulha suas raízes como a flor no gozo. É essa dominância da mulher na mãe que introduz o gozo na dimensão do ser do sujeito.

\begin{abstract}
A mulher permite ao gozo ousar a mascara da repetição. Ela aqui se apresenta como o que é, como instituição da mascarada. Ela ensina seu pequeno a se exibir. Ela conduz ao mais-de-gozar porque mergulha suas raízes, ela, a mulher, como a flor, no gozo mesmo. Os meios do gozo são abertos pelo seguinte princípio - que ele tenha renunciado ao gozo alheio, à mãe (Lacan, 1992, p.74).
\end{abstract}

Pela ação do significante o gozo só se inscreve como perda, mas, ao mesmo tempo, é a própria linguagem que projeta o mais além de um gozo Outro. A perda de gozo gerada pela entrada na linguagem instala o infans na posição de objeto de gozo do Outro. Lacan (2005) vai dizer que é na medida em que o sujeito tenta fazer esse gozo entrar no campo do Outro que ele se antecipa e se faz desejante.

A violência do corpo a corpo entre a criança e a mãe é, entretanto deslocada pela fala que acompanha os cuidados maternos. O que se passa entre mãe e criança não se desenrola como uma cena muda. É na medida em que a mãe fala esses cuidados, que algo da erogeneidade despertada pode ao mesmo tempo ser cortada. A fala materna tem valor de teoria para a criança em face do que ela experimenta em relação à excitação despertada nas zonas erógenas. O discurso que a mãe articula junto à criança introduz o simbólico no tocar, algo do contato é deslocado. "É nas palavras que a mãe põe sobre essa surpresa, sobre esse experienciado, que se encontra encadeado algo que vai acompanhar a excitação determinada pelo tocar" (Bergès e Balbo, 2002, p. 65). Nessa perspectiva, o amor da mãe tem valor constituinte do sujeito, pois o amor realiza uma abertura para o ser da criança. 
A fala materna recalca os excessos, coloca um termo na excitação, tanto para a criança como para ela, pois, afinal, a mãe também se excita com tudo isso. 0 discurso materno produz o sexual, as zonas erógenas e o recalcado. O recalcamento desse gozo despertado no corpo a corpo com a mãe é condição para que a criança chegue a articular uma teoria sexual infantil. Nesse dinamismo, a queda do objeto voz enquanto puro objeto fônico é condição para que a criança chegue a falar. O objeto deve cair, para que o caminho para a sublimação se abra ao sujeito. A hipótese de Bergès e Balbo é a de que as teorias sexuais infantis têm valor de sublimação, na medida em que a criança elabora aí esse limite que lhe foi imposto pelo Outro e nesse sentido ela é simbólica.

As manifestações musculares e tônicas do bebê já se oferecem como suporte, pontos privilegiados sobre os quais incidirão os cuidados da mãe. Vorcaro (2003), assinala que o funcionamento do agente maternante adere ao que no corpo do filho já se dispõe organizado pela oposição do significante. O simbólico no tocar impõe um limite a uma excessiva agitação desse corpo "[...] a fim de que haja divisão em relação a algo que se tornaria um gozo. No entanto, bem se vê o quanto se há excesso, esse excesso se arrisca, por sua vez, a se tornar um lugar erógeno" (Bergés e Balbo, 2002, p. 68). Se não há simbólico no tocar, há o risco de que a incidência desse tocar gere pontos de gozo nesse corpo. A função da fala materna incide sobre o corpo, ao limitar o excesso da excitação despertada, e cria bordas nesse corpo. Quando não há essa dimensão simbólica na tomada do corpo não há borda, mas buracos oferecidos ao gozo do Outro. As crianças hospitalizadas e que requerem cuidados intensivos confirmam a relevância do estatuto simbólico dos cuidados e o olhar da equipe terapêutica para o bebê. 
Partindo dessa condição - a de que o corpo já se oferece como marcado pelas disposições do significante -, Bergés e Balbo vão enumerar algumas situações nas quais tais condições conduzem a distintos impasses no encontro entre a mãe e a criança. Há crianças cujo corpo não se oferece como receptáculo e, nesse caso, elas se verão impedidas de chegar a fazer uma teoria sexual. Tal é o caso das grandes hipotonias na infância. O corpo da criança não se presta a provar, a receber os toques e a excitação. Nesses quadros hipotônicos, o corpo da criança cai nos braços da mãe totalmente mole, sem tonicidade, sem responder a qualquer surpresa que Ihe é apresentada pelo lado da mãe, seja pelo tocar, pelo olhar, pela voz, etc. As crianças estão transbordadas de saída, segundo Bergès e Balbo (2001). Os autores alegam que é necessário cautela com as prescrições de estimulação nesses casos. A estimulação deve se fazer pelo olhar e pela voz para que esse corpo não seja transbordado por inteiro, pois “[...] ao não poder ser receptáculo, é atravessado, esmagado, furado, virado pelo avesso" (Bergès e Balbo, 2001, p. 69).

A mãe de uma criança hipotônica pode ser levada à completa frustração e desistir de fazer qualquer hipótese de saber em seu filho, na medida em que nada do lado dele responde ao que ela Ihe envia. Nesses casos, o olhar acaba se tornando o único vetor de troca entre a criança e o outro. No entanto, para que o olhar seja estruturante para o sujeito, há que haver sua queda como objeto $a$, ou seja, que não haja uma fetichização do olho, ou seja, mais uma vez, que esse olhar seja signo de uma presença simbólica do Outro junto à criança. Com as crianças hipercinéticas ocorre, por outro lado, completa destituição da mãe como voz; o corpo dessas crianças é por inteiro receptáculo, quer dizer, as crianças renunciam ao que 
Ihes chega pelas orelhas, elas se mexem o tempo todo, mas elas não estão em parte alguma.

A condição da prematuridade clínica do bebê pré-termo também pode conduzir a mãe a não encontrar facilmente o caminho de endereçamento a seu filho. Como vimos no capítulo anterior, o bebê pré-termo é suscetível ao desequilíbrio de seu organismo na gestão dos estímulos que o alcançam, na medida em que a maturidade das estruturas nervosas cerebrais, no momento de seu nascimento, está em defasagem com a magnitude dos estímulos que ele tem de enfrentar na vida extra-útero. A instabilidade orgânica inicial do bebê limita as primeiras trocas afetivas e o corpo a corpo no qual se veicula o saber do amor da mãe. As várias condutas adotadas pela terapêutica do tratamento das patologias da prematuridade produzem situações que repercutem diretamente no laço mãe-bebê. O procedimento regular de monitoramento das funções vitais da criança que se acompanha freqüentemente pela necessidade de ventilar e entubar o bebê constitui uma imagem inquietante para a mãe, pois a priva de ouvir o choro de seu filho. Esta é uma constatação elementar: a importância para a mãe de poder ouvir o choro de seu bebê. Esse choro é uma declaração para ela de que ele está ali e da potência de sua presença na vida. Por outro lado, todo esforço realizado pelo bebê pré-termo envolve para ele um gasto energético que demanda uma compensação, para que ele possa recuperar o equilíbrio entre os sub-sistemas que compõem o sistema nervoso. A apatia do bebê pré-termo, embora repleta de efeitos sobre o agente materno não implica, entretanto, que ele seja uma criança com menos apetite do que outras pelo campo da fala e da linguagem. Grenet (1997) afirma, considerando todos os aspectos que o organismo dessas crianças tem de enfrentar, que a interação para o 
bebê pré-termo é um luxo, mas um luxo que ele requer, talvez mais do que outras crianças. O limite entre o excesso e a falta de contato com o bebê pré-termo é sempre uma questão a ser avaliada. No entanto, podemos verificar o quanto que para essas crianças a relação ao semelhante é de vital importância para que os cuidados que ela recebe, tanto através dos procedimentos invasivos, como pela ligação às máquinas, não sejam portadores de um caráter desumanizante, ou seja, corrosiva para a estruturação da continuidade das experiências pré e pós-natais.

Quando a mãe não pode fazer uma hipótese de saber em seu filho, é toda a dimensão da articulação entre o simbólico, o imaginário e o real na construção do corpo que se encontra em risco. Quando a mãe não pode antecipar no bebê o que ainda não está ali, o que fica em risco é a possibilidade de a criança fazer a experiência do espelho que constitui a base de sua relação com o semelhante. 0 sentido da unificação corporal que toma corpo no olhar da mãe assegura ao bebê as condições para gerir as excitações que incidem sobre o seu corpo.

É a partir dessa unidade que o eu humano começa a assumir suas funções. O eu humano, portanto, se constitui sob o fundamento dessa relação à imagem, vista antes - e sancionada - pelo Outro, em que o organismo toma corpo - ou em que a constatação de ter um corpo captura e conquista o organismo. Ou seja, o sujeito investe em si mesmo através do Outro (Vorcaro, 2003, p.211).

Bergès e Balbo apontam que o que ocorre com as crianças (hipotônicas ou hipercinéticas) nos leva a ter que considerar que houve fracasso, não pelo lado do pai que faltou para colocar um limite, um termo, que permitisse à criança encontrar seu lugar. O que fracassou deve ser buscado pelo lado do materno. As condições em que se declara uma falha ao nível da estruturação da imagem do corpo levam a revisar o estatuto a ser conferido aos cuidados maternos. A função materna cumpre 
a função de pára-excitação para o recém-nascido, pois ao mesmo tempo em que desperta uma excitação das zonas erógenas através dos cuidados, evita, concomitantemente, que haja transbordamento de gozo. Quando os cuidados da mãe não conjugam esse limite pode-se estimar que há uma falta de simbolização pelo lado da mãe do corpo da criança. Nos parece que é por essa via que podemos entender a posição de Mathelin (1997) em relação aos cuidados dispensados ao bebê pré-termo durante o período de reanimação neonatal. A autora afirma que o corpo pode ser furado sem que se fure o simbólico. Tudo depende do sentido conferido à hospitalização da criança e de que ela seja, desde o início, tomada como um sujeito portador de uma história, e não apenas um pedaço de carne a ser reparado.

Quando Freud aponta que o comércio sexual entre mãe e criança é o caminho obrigatório pelo qual a mãe ensina o amor ao filho, podemos ler nessa indicação, acompanhando Bergès e Balbo, que o amor da mãe se coloca no intervalo entre o desejo e o gozo, impondo um limite ao que se arriscaria a ser um gozo desmedido para o sujeito. Lacan (2005), afirma que só o amor permite ao gozo condescender ao desejo.

De acordo com a lógica transitivista a criança, num primeiro momento, é tomada pela mãe como encarnação de sua necessidade de amor, ela encarna o objeto a de sua necessidade. Quando ela grita, ela lhe dá por amor a fome e depois o alimento. Bergès e Balbo (2002, p. 70) colocam que, se tudo parece tão natural entre mãe e filho, é porque a mãe, ao fazer essa hipótese de saber "[...] toma a criança como encarnação real do sujeito do inconsciente, que é o seu [...]". 
A identificação da criança ao falo imaginário é sustentada pela ilusão amorosa de que ela corresponde ao objeto a da necessidade de amor da mãe. No entanto, a articulação da necessidade pelo significante gera defasagem, intervalo, nãocoincidência entre aquilo que a mãe fez como hipótese de saber na criança e aquilo que ela experienciou. Lacan (1992) afirma que a articulação da necessidade pelo significante produz um mais além que é demanda de amor, e um aquém que é a margem do desejo. O intervalo cavado pelo relançamento da demanda à criança nunca chega a corresponder às expectativas do saber materno. A criança se encontra, desse modo, no caminho de realizar a mãe como um Outro e a formular: mas o que ela quer?

O momento em que algo do amor da mãe se encontra desviado da criança, ou seja, em que ela encontra a dimensão do desejo do Outro, é a queda do amor como objeto a da necessidade da mãe. É nesse momento que Bergés e Balbo situam o ponto de torção que possibilita que a criança venha a realizar esse objeto a como causa de desejo de sua mãe e, portanto, a produzir a sua teoria sexual infantil.

O olhar da mãe para a criança é um olhar que participa da obliqüidade, pois ela não a toma como um objeto real ou como um simples prolongamento de seu corpo. "[...] o olhar sublime [...] é um olhar que faz jogar as sombras, as diferenças e, de imediato, torna possível uma certa leitura do corpo da criança" (Bergès e Balbo, 2001, p. 41). A possibilidade da teoria sexual infantil se manifesta nessa falha, nessa disjunção entre "[...] a gestalt (ligada aos instintos animais) e as imagos (o conhecimento). A imagem não é necessariamente imaginária" (Bergès e Balbo, 2001, p. 50). 
O amor da mãe, por não ser inteiramente especular, consente que haja separação entre ela e a criança. É nesse sentido que a experiência do espelho tem valor de castração simbólica para ela. O testemunho requerido pela criança à mãe diante do espelho corrobora que ela como Outro não é tudo para a criança.

Para que esse processo possa se produzir, é necessário que o narcisismo da mãe seja tal, que possa suportar ver-se cair, tanto como duplo do filho como dela mesma. Entre mãe e filho há sempre um falo: de início, um falo imaginário, e ele deve cair, para que o falo simbólico venha se situar entre eles, de modo a separá-los, dando lugar à castração simbólica. Assim, é a própria criança que é o motor da castração (Bergès e Balbo, 2002, p. p.57).

Se a mulher, na condição de mãe, não se encontra dissuadida de encontrar no corpo de um homem o significante de seu desejo, a sua necessidade de amor é desviada da criança e é o amor como objeto a que cai. O avatar do amor materno, nesse caso, é solidário da condição da criança como metáfora do amor da mãe pelo pai e nesse sentido esse amor é tributário da sublimação, pois há a criação de que algo que não havia.

O amor materno visa à constituição do ser da criança, e para que o vir a ser da criança possa se cumprir, a mãe empresta seu corpo, seus significantes, seus devaneios, seu olhar, o seio, a voz, etc. O amor situa e articula dois campos heterogêneos: o campo das pulsões parciais e o campo do narcisismo. É essa conjugação que permite a Chaumonn (2006) dizer que a função do amor materno é a de vestir o real do organismo com uma imagem, uma vez que a mãe vê o bebê como ela o ama, adornado-o de todos os atributos que o fazem perfeito.

Sabemos que não é desse modo que, freqüentemente, as mães dos bebês pré-termo vêem seu filho, pelo menos não num primeiro momento. No entanto, como 
tudo que diz respeito ao sujeito escapa à universalização, tentemos entender um pouco melhor as possibilidades que se apresentam no encontro dos pais com o bebê. Verificamos que alguns pais, ainda que transbordados pelo encontro com o horror de sua criança prematura, são convocados a um empuxo de saber que vem paliar e circunscrever algo desse horror.

\section{UM AMOR TERCEIRO OU O FILHO COMO TERCEIRO?}

Rita e Gustavo vivem juntos há quatorze anos e no primeiro encontro comigo descrevem o enorme susto e sofrimento que tiveram quando Rita chegou ao $6^{\circ}$ mês de gestação. Ela começou a desenvolver um quadro de pressão alta e passou a receber acompanhamento mais rigoroso da gestação. Logo no início desse acompanhamento veio a ser internada, e ao ser constatada uma redução importante do líquido amniótico após três dias de internação, ela foi submetida a uma cesárea de urgência. O casal descreve o verdadeiro pavor que viveu nesse momento, pois foram alertados pelo médico que o bebê poderia nascer sem vida, além do risco de vida que ela corria. Eles repetem, ao longo da entrevista, que não é fácil passar por tudo isso: "Imaginávamos que após o nascimento do filho, todos nós iríamos para casa". Gustavo disse ter ficado muito dividido após o nascimento do filho, já que, até então, "era tudo para ela e agora é tudo para o bebê". "Preocupava-se como ela reagiria a tudo. Se Rita teria uma depressão, se ela conseguiria suportar tudo o que estava diante dela. Aqui no hospital ninguém esconde nada sobre o estado de saúde da criança. Contam a verdade mesmo que seja difícil". 
Rita comenta que, quando soube da decisão de realização da cesárea, passou um filme em sua cabeça sobre toda a gestação. Ela se perguntava o que tinha dado errado. Se ela tinha feito algo errado, ou se havia levado um susto. Recordou, então, que uma vez estava passeando com o marido no bairro onde vivem, quando os cachorros do vizinho se soltaram e eles levaram o maior susto. Ela então relata: "A gente se sente culpada não é? O médico disse que eu não fiz nada de errado. O bebê não estava se desenvolvendo". Rita diz que sente ainda como se o bebê estivesse na barriga dela. "E por outro lado, é como se ele não fosse meu. Não é fácil, pois quando chego em casa, está tudo lá, o berço vazio e as roupas penduradas. Gustavo montou o berço no $4^{\circ}$ mês de gestação". Ela se pergunta: "por que é que essa pessoa tinha que chegar agora? Sabe que o chá de bebê vai ocorrer daqui a duas semanas? Eu vou fazer, mas é uma loucura não é?"

Quando souberam, durante a gestação, dos riscos que o bebê corria, se comunicaram com o Padre Marcelo através de seu programa de rádio. O Padre Marcelo disse que a criança viveria. O nome do filho já estava escolhido há uns dez anos. Miguel é um nome bíblico. Já o anjo Gabriel foi aquele que abençoou Isabel que era estéril.

Rita e Gustavo pensavam em ter filho, mas eram "muito descansados". Eles residiram durante quatro anos com a família dela e depois um tempo no sítio dos pais dele que não desejavam ficar sozinhos. Decidiram voltar a morar com os pais dela até que perceberam que era o momento de ter sua própria casa e privacidade. Ela se diz muito ligada à família dela, uma família que ela descreve como tipicamente italiana: "alegre e barulhenta". Os irmãos têm filhos e todos moram 
próximos aos pais. No entanto, diz que quando alugaram uma casa para eles, que "não deu outra: ela engravidou". Já Gustavo tem um irmão que não tem filhos, pois é estéril. Rita comenta que o marido foi um bebê prematuro e que sua mãe não havia desejado a gravidez.

Eles insistem em dizer que estão experimentando um amor muito diferente em relação ao filho: "É um amor total. É diferente do amor que sinto pelos meus pais e diferente do amor que eu e meu marido temos um pelo outro. É um terceiro amor". Rita comenta que o retorno para casa sem o bebê "foi muito difícil". Ela se refere a um desentendimento com o marido no dia de sua alta porque ele queria "fazer um buzinaço quando chegasse em casa". E continua: "Eles, homens, são todos iguais". Ao conversar com as outras mães no hospital ela percebe que elas passam por coisas muito parecidas. O marido de uma delas queria fazer um churrasco quando voltaram para casa. A esposa retrucou: "Você está louco. Vamos comemorar o que? Nosso filho está no hospital". Uma outra mãe comenta que o marido, no dia de sua alta, levou para ela um chinelo tamanho 40 e uma calça que não lhe servia. Rita prossegue: "Imagina se eu ia deixar ele fazer um buzinaço. Eu não estava voltando para casa com o bebê, estava toda descabelada e com dores da cesárea". Eles se tratam carinhosamente, e Gustavo diz já saber tudo sobre bico e amamentação. Ele diz que às vezes fica meio constrangido no meio de tantas mães e decide dar uma volta. Em outros momentos, encontra um outro pai e vai conversar.

O bebê de Rita e Gustavo embora bastante prematuro, em pouco tempo de internação teve todo auxílio respiratório retirado. Gustavo comenta: "dá até medo de ver o filho, mas que é muito bom vê-lo evoluindo bem". A primeira vez que pegaram 
seu filho no colo foi de muita emoção. Afirmam que estão sempre pensando nele em tudo o que fazem: "Antes andávamos correndo de moto. Agora vamos mais devagar. Achamos que muita coisa muda com a chegada do filho". Os familiares vieram ver o bebê e o comentário da enfermeira de que ele era a cara do avô paterno deixou o avô cheio de orgulho. Miguel é o primeiro neto dos avós paternos.

Os progressos de Miguel são acompanhados com interesse e envolvimento pelos pais. Rita se preocupa com tudo o que é feito com o bebê e fica muito sensibilizada quando é necessário realizar algum procedimento ou exame com ele. Ela conta que em uma ocasião chorou muito durante a avaliação oftalmológica a que ele teve que ser submetido. Os pais sempre comentam que, apesar de seu otimismo com relação ao filho, é sempre chocante todo o ambiente em volta da criança: "Outro dia o bebê que se encontrava na incubadora ao lado da de nosso filho morreu. Não tem como não ficar abalado com isso". Embora os pais estejam mais próximos do bebê, Rita sabe que ele não é todo seu. "Foi a enfermeira que viu o umbigo dele cair, foi ela que trocou a fralda dele um monte de vezes. Não vejo a hora de começar a amamentá-lo".

A passagem de Miguel para a sala de tratamento semi-intensivo foi assim interpretada pela mãe: "Ele foi promovido". O início do aleitamento foi bastante gratificante para ela que ficou também bastante feliz por começar a dar banho nele e trocar suas fraldas. O pai, então, comenta sobre o filho: "Agora ele tem um corpo, antes era só um fio". Miguel reconhece a voz de ambos e já revela ter um temperamento, segundo os pais. 
Há vários elementos a serem destacados nesse fragmento. Vemos que Rita e Gustavo nomeiam toda a experiência vivida por eles como uma experiência de pavor. Eles descrevem o período que antecede o nascimento de seu filho como uma turbulência que inscreve esse nascimento como um susto. Há vários momentos em que o termo "susto" comparece na fala dos pais durante os primeiros dias que se seguem ao nascimento do bebê. No capítulo anterior, já havíamos apontado que Freud (1920/1976) havia definido que a presença do susto (Schreck) é solidária da falta de preparação para a angústia enquanto sinal de alerta a uma situação de perigo, isto é, como sinal daquilo que pode constituir uma situação traumática para o sujeito. Observemos que o casal, no momento em que é notificado, durante a gestação, sobre o não desenvolvimento da criança, apela para um Outro que faz a função de oráculo e os tranqüiliza ao decretar que: "A criança viverá". Esta fala, de algum modo, faz a função de contenção desse primeiro transbordamento que ameaça esmagar subjetivamente os pais.

É interessante notar que o nome da criança, Miguel, já havia sido escolhido há muito tempo, ou seja, já havia um lugar reservado para ela no desejo do Outro. Os pais dizem que Miguel, no contexto bíblico, é aquele que traz a cura. Vale, entretanto, notar, que o nome da criança ligado a uma função bíblica, o anjo Miguel, é ligado no seu relato com a função de outro anjo, o anjo Rafael, que é aquele que vem dar a notícia de que Maria porta um filho de Jesus, ao mesmo tempo em que é aquele que também contempla Isabel, que é estéril, com uma criança. O anjo Miguel, por sua vez, na referência bíblica, é o príncipe da milícia celeste, o batalhador, aquele que extermina Lúcifer - o anjo da maldade. O lapso que condensa o anjo Miguel com o anjo Gabriel - este sim, segundo a referência bíblica, 
sendo aquele que traz a cura -, reúne numa só figura aquele que combate o mal e aquele que possui o dom da cura. A referência contígua ao anjo Gabriel, por sua vez, aponta para a questão da infertilidade. Pelo lado do pai, encontramos tanto a marca da criança não desejada como a da esterilidade. Pela vertente da cura, poderíamos pensar que a vinda dessa criança cura algo nos pais. Observemos que ambos declaram a realização de um ato, o de buscar uma casa para eles, "sair da acomodação", como concomitante à gravidez de Rita. Em sua fala há uma certeza de que tal decisão os extrai de uma espécie de adolescência prolongada e os conduz a um outro lugar de inscrição na cadeia geracional. Eles deixam de ser filhos para tornarem-se pais. O susto é também de outra ordem.

Chatel (1995), observa que tudo aquilo que diz respeito aos avatares da fecundidade humana é inseparável do fato de sermos habitados pelo simbolismo da linguagem, a copulação é, antes de tudo, uma copulação entre os significantes.

É em função daquilo que dizem, do que se diz em torno deles e também das rupturas ocorrenciais que Ihes acontecem na realidade [...] que certos significantes são reativados e agem, que a fantasia da procriação de cada um consegue se realizar. [...] A mulher, no desejo sexual com um homem, reencontra neste um significante que, realizado num ato [...] vai desencadear a fecundação, tal como um ato falho. [...] Para o homem, o desejo de criança é, na maioria das vezes, o desejo de encarnar este símbolo do dom criador para aquela que ele encontra [...]. Nos seres falantes, a fecundação é uma somatização: ela realiza uma precipitação (no sentido químico) em substância do cruzamento dos desejos inconscientes (Chatel, 1995, p. 17).

Essa conjunção significante que o nome próprio da criança aglutina situa-a como um terceiro para os pais. Há algo dessa ordem que se exprime na fala deles de vários modos. O amor pelo filho é algo totalmente inédito, terceiro, diferente daquilo que um sente pelo outro e do que ambos sentem pelos pais. Tudo ficou 
diferente para eles após o nascimento do filho. A alusão à diferença sexual comparece na fala de Rita ao dizer que os homens nada sabem daquilo que se passa quando uma mulher dá a luz. Eles querem comemorar enquanto elas estão desalinhadas, descabeladas, e as dores do parto recém ocorrido faz marca, furo, no corpo. A presença de uma certa tensão entre eles é como uma novidade, algo que desloca a antiga camaradagem que reinava entre eles.

Eles apontam que esse nascimento é também um drama, é tudo muito difícil. Retornar para a casa sem o bebê, ter de olhar o quarto todo pronto, o berço armado e as roupas penduradas. O chá de bebê que está prestes a ocorrer e o bebê, contudo, tendo de enfrentar uma luta para sobreviver. Está tudo lá menos o bebê.

O relato dos pais revela a diferença no modo como cada um enfrenta o acontecimento desse nascimento. O pai fala de sua divisão: "antes era tudo para ela e agora é tudo para ele". Ele está entre a mãe e o bebê. Ele está dividido entre acompanhar os primeiros instantes do nascimento do filho e se preocupa em como sua mulher enfrentará tudo aquilo: "Será que ela vai deprimir?". Ele se desloca entre a UTI neonatal e o quarto de sua mulher. Comparece também em seu relato um certo embaraço quanto a encontrar seu lugar nesse nascimento. Gustavo afirma, num segundo momento, que já sabe tudo sobre bico e aleitamento, mas diz que de vez em quando ele se retira para dar uma volta, fica meio constrangido naquele ambiente.

Mathelin (1997) aponta, a esse respeito, que nos nascimentos prematuros há uma inversão que afeta o lugar do pai, pois, se freqüentemente é a mãe que vai 
apresentar a criança ao pai nesses nascimentos, é o pai que vai levar a criança até a mãe. Para o pai o bebê é um outro que não se faz reconhecer pelo corpo a corpo que marca a relação entre a mãe e o bebê. A autora nos diz que é muito importante, nessas condições, não confundir o lugar do pai como sendo co-extensivo ao lugar de uma boa mãe. Já que freqüentemente os pais são incentivados, durante a hospitalização do bebê, a entrar nesse corpo a corpo com o filho, convém observar que tal situação pode promover um deslizamento do pai para um lugar maternante. Esse deslizamento comporta para ele um certo risco de feminilização, na medida em que tal posição reanima a identificação precoce com a mãe. "Os partos prematuros, em que a mãe e o filho estão em perigo, fazem bascular os pais nos tormentos da castração e das identificações impossíveis" (Mathelin, 1997, p. 104).

Por outro lado, a fala de Gustavo testemunha que o nascimento de uma criança repercute pelo lado do pai os efeitos da divisão pelo não-todo do desejo feminino. Gustavo afirma que antes era tudo para ela e agora é tudo para o bebê. Mas e ele, onde se encontra nisso?

\footnotetext{
Essa divergência do desejo feminino sobre a criança é, nesse caso, motivo de angústia para o pai, desta vez, segundo a outra fórmula da angústia, que relaciona o incômodo da angústia à emergência do desejo do Outro como enigma do ser. Nessa circunstância, portanto, é o nascimento da criança que provoca o retorno da angústia ao pai: Que quer ela então? Quem sou eu, pois, para ela? Um homem, eu diria, só se torna pai se aceitar o não-todo que constitui a estrutura do desejo feminino (Miller, 1996, p.10).
}

Pelo lado da mãe, verificamos que ela testemunha que a criança não the concerne por inteiro. Ela afirma que parece que a criança ainda está em sua barriga e que "Não foi ela que viu o umbigo cair, que deu o primeiro banho, e que dispensa os cuidados ao bebê". No momento do parto, ela descreve que a gestação passa 
como um filme para ela. Ela pensa: "o que fiz de errado?". As mães sempre se sentem culpadas por não terem conseguido levar a gestação a termo. Elas tentam entender e dar sentido a esse nascimento. Elas levantam inúmeras hipóteses: Terá sido o repouso não realizado conforme a recomendação médica? Poderá ter sido porque exagerou nos serviços domésticos? Será que foi porque ela fumou? Será que foi por causa do nervoso que ela passou na gravidez? Será que foi devido ao medicamento que ela tomou quando ainda não sabia que estava grávida? Enfim, as mães buscam encadear algum sentido a tudo aquilo.

Vale notar, entretanto, que tanto para Rita como para Gustavo, a prematuridade da criança é enfrentada com um empenho e um entusiasmo que, por vezes, desperta na equipe um leve incômodo. Para a equipe, às vezes, a conduta desses pais parece comportar um certo excesso, como se esse excesso traduzisse alguma forma de negação da realidade da morte que paira sobre uma UTI. Não nos parece poder ser descartada a presença desse excesso, mas poderíamos situá-lo em outro lugar, de modo a não confundi-lo com uma inadequação de conduta.

Esse excesso parece caminhar junto com a própria angústia experimentada pelos pais diante do desmedido que cercou esse nascimento, um desmedido que se situa tanto pelo lado do gozo, "dá medo de olhar para ele, mas também é bom ver ele melhorar", como pela vertente do desejo. Há, para esses pais, um limite que foi franqueado pela concepção da criança, eles saíram de uma zona de conforto, foram arrancados de "uma situação de acomodação". A criança, como terceiro, os remete à dimensão do desejo sexual. 
Rita e Gustavo, muitas vezes, ao se referir ao bebê, revelam que essa criança, embora ainda frágil, Ihes inspira um certo respeito. O bebê prematuro, muitas vezes, se reveste para os pais de um dom que exprime que ele é portador de uma força própria para enfrentar o seu destino. Ouvimos de muitos pais a seguinte afirmação: "ele é valente e eu tenho que ser forte também". De certo modo, esse olhar e essa suposição de saber no bebê é corroborado, em alguns momentos, pela equipe que, desse modo, convoca os pais a enfrentarem com o bebê o real desse nascimento. Não é, entretanto, descartável, que essa fala da equipe ateste para ela a dimensão enigmática do bebê. Mathelin (1997) recorda que em algumas tribos africanas o bebê é detentor da alma de um ancestral e, a este título, ele se torna detentor de um saber infinito.

Ansermet (2003), por sua vez, fala do mito da criança exposta, ou seja, daquele que muito precocemente foi confrontado com uma situação de perigo fora do comum, seja o do risco de morte física, psíquica ou cultural. O autor se refere à saga de Édipo, a criança de pés furados, que foi salva pela mediação simbólica, quando acolhida pelos braços de um outro que não seu pai, um pastor, que evitou a realização do voto paterno infanticida. O furo é a marca do acolhimento simbólico. O autor aponta, seguindo a teoria de Rank sobre o herói, que a criança exposta encontra-se no coração do nascimento do herói, pois aglutina certos traços específicos ao romance familiar do herói.

O herói é filho de pais eminentes. Seu nascimento é precedido por dificuldades como abstinência, a esterilidade, as relações clandestinas. Um presságio vem alertar contra seu nascimento e anunciar um perigo, em particular para o pai. O recém-nascido é então destinado à morte, ou à exposição, em geral instigada pelo pai.[...] Em seguida, é salvo por animais ou pessoas socialmente inferiores, por exemplo, pastores. Crescido, reencontra, após várias 
aventuras, seus nobres pais e se vinga de seu pai. Reconhecido, alcança a glória e a fama (Ansermet, 2003, p.80).

A negação da gravidade da criança, "nós imaginávamos que após o nascimento iríamos todos para casa", não deixou de protegê-los do que havia de impensável naquele nascimento. A referência permanente em sua fala sobre aquele amor desconhecido, terceiro, poderia ser efeito do espanto em face da presença enigmática do bebê. Poder se autorizar a esse amor desde o início, quando tudo sobre a vida daquela criança ainda estava por se decidir, tornou todo o percurso desses pais mais suportável. Nesse caso, a criança não faltou ao seu chamado, pois ao final da hospitalização ela já não era um fio, de vida, mas tinha corpo e temperamento.

\section{VICISSITUDES DO AMOR MATERNO}

Winnicott (1956b) captou, com muita perspicácia, um dos avatares da função do amor materno ao descrever o estado de preocupação materna primária. Essa noção marca uma distância em relação a todo tipo de naturalização da função da mãe, pois para o autor é "[...] necessário resgatar o estudo das necessidades maternas do campo puramente biológico" (Winnicott, 1956b, p. 492).

O estado de preocupação materna primária corresponde a uma disposição especial da mãe em relação a seu bebê que se organiza como um estado provisório e que permite a ela uma identificação a ele. Esse estado é mobilizado no último trimestre da gestação e mantém seu vigor nos primeiros tempos após o parto. 0 
autor compara a condição da mãe a um estado psiquiátrico muito especial, uma doença, se não fosse a gravidez (grifo nosso).

Não acredito que seja possível compreender o funcionamento da mãe na fase mais inicial da vida de um bebê, sem entender que ela deve ser capaz de atingir esse estado de sensibilidade aumentada, quase uma doença, e recuperar-se dele. (Introduzo a palavra doença porque é necessário que a mulher seja saudável, tanto para desenvolver esse estado, quanto para recuperar-se dele quando o bebê a libera. Se o bebê morre, o estado materno surge repentinamente como uma doença. A mãe assume este risco) (Winnicott, 1956b, p.494).

Trata-se de uma loucura normal que é induzida na mãe pela presença do bebê e é o bebê que a libera para que ela passe para outra coisa. O momento em que o bebê revela não se encontrar inteiramente mergulhado na condição de dependência em relação a ela é, concomitante, a retomada pela mãe de seus outros interesses: ela volta ao seu trabalho, à sua vida erótica com o parceiro conjugal, etc. A paixão materna que comanda o exercício da função materna é indissociável da presença do bebê, pois "[...] a partir do momento em que a criança não está mais na posição de objeto "natural" dessa paixão - isto é, quando deixou de ser o infans objeto do amor narcísico - esse estado poderia parecer ao terceiro um verdadeiro estado de loucura" (Chamoun, 2006, p. 168). Corroborando essa íntima ligação entre a paixão materna e a presença do bebê, Winnicott (1956b) conclui que esse estado sucumbe ao recalcamento, a mãe nada sabe dizer disso que se passou com ela.

A mãe que desenvolve essa doença será capaz de criar um ambiente propício ao desenvolvimento do potencial do bebê. Winnicott utiliza o termo 'devotado' para se referir a essa qualidade da mãe, "mãe comum devotada". De 
início, o bebê parece ser parte dela mesma. Ela se identifica com ele e nesse momento são mobilizadas as próprias experiências da mãe como bebê, ou seja, a própria maternagem que ela recebeu de sua mãe. Vale destacar, que para o autor não nos parece, entretanto, se tratar de uma transmissão da maternalidade, pois, segundo sua perspectiva, a mãe é re-criada, a cada vez, pelo bebê, ou seja, cada bebê fabrica sua mãe.

O estado de preocupação materna primária não tem nenhuma relação com a inteligência nem com a instrução ou com a competência na técnica da maternagem. As mães não podem ser conduzidas a tal estado por intermédio da instrução ou do aprendizado. O autor alega que alguns fatores podem constituir um impedimento para a mãe chegar a alcançar esse estado, embora elas sejam capazes de serem boas mães sob outros aspectos.

Pode-se supor a existência de uma "fuga para a sanidade". Algumas delas podem ter preocupações alternativas muito grandes, que não abandonam facilmente, ou podem bloquear esta entrega até que tenham tido seus primeiros bebês (Winnicott, 1956b, p. 494).

Por outro lado, quando as mães ficam boas demais na técnica de criar suas crianças, fazendo tudo certo na hora certa, elas não permitem que seus filhos se apossem do controle sobre as coisas boas que estão acontecendo a eles, isto é, impedem o processo de separação. O gesto criativo, o choro e os protestos perdem sua função quando a mãe satisfaz rápido demais as necessidades do bebê, como se ele estivesse ainda fundido com ela, vale dizer, quando ela não permite que seu bebê faça uma demanda. É, assim, possível prover um cuidado inicialmente bom, mas fracassar pela incapacidade de deixá-lo terminar. "[...] é uma tarefa difícil para a 
mãe se separar do lactente com a mesma rapidez com que o lactente precisa ficar separado dela" (Winnicott, 1960, p. 52).

A tarefa da mãe é a de fornecer um setting que assegure ao bebê a continuidade, a mesmice, do sentimento de existir, de ser. Quando a provisão ambiental oferecida ao recém-nascido é satisfatória, ele poderá exibir suas próprias tendências de desenvolvimento. Winnicott (1956b) postula que o estado correspondente no bebê às condições que se observam do lado da mãe são as seguintes: o bebê tem uma constituição, suas tendências inatas de desenvolvimento, sua motilidade e sensibilidade. Há um trabalho silencioso e subterrâneo das satisfações pulsionais que a mãe provê ao bebê e esse trabalho diz respeito à construção das bases do ego.

O self individual começa como uma soma de experiências de repouso, motilidade espontânea e sensação, retorno da atividade ao repouso, e o gradual estabelecimento de uma capacidade de aguardar a recuperação das aniquilações; aniquilações que resultam das reações às invasões ambientais. Por esta razão, é necessário que o indivíduo comece no meio de um ambiente especializado, ao qual me referi como Preocupação Materna Primária (Winnicott, 1956b, p. 498).

Concordamos com Chaumon (2006) quando afirma que a certeza louca que autoriza a mãe à interpretação das manifestações de seu bebê não é a certeza delirante da psicose, pois esse saber da mãe é um saber que lhe vem do amor.

Para Freud (1914) o amor dos pais é a prova irrefutável de que há narcisismo primário, pois esse amor pela criança revela ser, no fundo, um retorno de suas antigas aspirações infantis. Os pais acham-se sob a compulsão de atribuir ao filho todas as perfeições, ocultando suas deficiências. 
Além disso, sentem-se inclinados a suspender, em favor da criança, o funcionamento de todas as aquisições que seu próprio narcisismo foi forçado a respeitar, e a renovar em nome dela as reivindicações aos privilégios de há muito por eles próprios abandonados. [...] A doença, a morte, a renúncia ao prazer, restrições a sua vontade própria não a atingirão; as leis da natureza e da sociedade serão ab-rogadas em seu favor; ela será mais uma vez realmente o centro e o âmago da criação - Sua Majestade o Bebê, como outrora nos imaginávamos (Freud, 1914, p. 108).

Há, então, uma relação positiva entre o amor materno e o narcisismo primário da criança enquanto núcleo do ser. É o amor da mãe que vem permitir que a reserva narcísica se disponha em seu justo lugar para seu filho, de modo que ele possa experimentar o sentimento da continuidade de existir. Uma parte dessa reserva libidinal original não é inteiramente vertida aos investimentos objetais. Uma parte da libido que fica retida no eu, ao nível do corpo próprio, não é transferida aos objetos. Lacan (2005) vai partir desse ponto para retomar a lógica do espelho no seminário da angústia, destacando que nem todo o investimento libidinal passa pela relação especular, algo está cortado, há um buraco real na imagem. Assim, quando algo vem se dispor nesse lugar onde seria esperado haver um vazio, há angústia.

Chaumon vai reunir um certo conjunto de hipóteses e de articulações para distinguir alguns avatares do amor materno. A autora parte dessa doença normal da mãe, o estado de preocupação materna primária, e reserva o termo loucura materna para descrever algumas outras manifestações que declaram uma desordem importante no laço de amor da mãe com a criança. Refere-se particularmente à condição do amor exclusivamente narcísico, em que a relação da mãe à criança não admite nenhuma transcendência, ou seja, quando a mãe só vê a si mesma na criança. Num outro pólo, encontrar-se-á a impossibilidade de a mãe dispor do recurso do amor narcísico. Nesse caso, a mãe fica inteiramente exposta à 
violência da nudez do corpo pulsional da criança. Consideramos que esse risco se apresenta regularmente para a mãe do bebê pré-termo. Vejamos, seguindo o texto de Chaumon, como melhor compreender alguns aspectos da experiência dessas mães.

A operação materna está diretamente concernida na hipótese de que é o amor da mãe que provê a criança com essa reserva narcísica que vai assegurar que ela possa realizar a experiência do espelho. É a mãe que vai oferecer à criança uma imagem na qual ela possa se contemplar como corpo unificado. O milagre do amor materno consiste em que a mãe vê o seu bebê não como ele é, mas como ela o ama. O amor da mãe "veste o real desse corpo gozante, dessa coisa que é a criança recém-nascida" (Chaumon, 2006, p. 175). Laznik-Penot (1998) formula que há um reconhecimento inaugural não demandado pela criança, mas que é précondição para que ela chegue a realizar a identificação ao espelho. Esse reconhecimento inaugural está ligado à capacidade de a mãe antecipar o que ainda não existe. O sujeito desse olhar não é a criança, mas o Outro materno.

Quando a mãe olha para a criança, ela nega sua incoordenação motora e suas insuficiências, segundo a lógica do transitivismo. É a operação especular que vai permitir que as zonas erógenas despertadas no exercício dos cuidados maternos venham a ser ligadas por essa imagem. Chaumon (2006) aponta que o amor da mãe é a dimensão que vai enodar duas ordens heterogêneas: a lógica pulsional, que coloca em jogo o recorte e a queda do objeto, e as exigências do ser, cujo fundamento se encontra no campo narcísico. A autora bem lembra o que 
Freud coloca sobre o amor dos pais: que ele caminha sem nenhuma contradição com a negação da sexualidade da criança.

Na versão do esquema óptico, introduzido no seminário da angústia por Lacan, fica interceptada a possibilidade de uma equivalência imaginária entre i (a) libido do ego enquanto corpo próprio - e i'(a) - libido de objeto. Há um resto na operação de constituição subjetiva, o objeto a. (Dor, 1995). Esse remanejamento do esquema é solidário ao destaque que será dado nas elaborações sobre a angústia com a função estruturante da falta. O estatuto real do objeto a se opõe à lógica unificante do espelho. Nem todo investimento libidinal passa pela imagem, o objeto a é não-especularizável. Quando a falta vem a faltar, há angústia.

Veremos agora como avançar em nossa análise sobre o impacto do nascimento prematuro para a mãe do bebê pré-termo. Temos insistido que as condições do nascimento prematuro dificultam, de saída, que a mãe possa sofrer essa doença positiva, isto é, a preocupação materna primária que vai ser operante no laço mãe-criança. O impacto sofrido freqüentemente pela mãe se traduz pela presença da angústia. É comum dizermos que ela é confrontada de maneira abrupta ao hiato entre o bebê imaginário e o bebê real. Vale lembrar que vários fatores se encadeiam a esse ponto: o risco de vida que acompanha o bebê após o nascimento, a notícia de que além das patologias da prematuridade clínica do bebê se superpõe uma deficiência congênita, a interposição da equipe médica entre a mãe e o bebê, a resposta do bebê aos cuidados intensivos, o maior ou menor apoio que a mãe recebe do seu parceiro ou da família, a incerteza quanto à presença de seqüelas 
futuras na criança ou a presença de seqüelas geradas pelas manobras realizadas no parto, etc.

A dimensão dos efeitos do risco de que padecem essas crianças constitui uma ameaça à maternidade da mãe. De início, não é a mãe o agente do saber sobre a criança, pois o que se coloca primeiramente como mestre desse saber é o discurso médico. Há um adiamento do encontro com o bebê que, associado às suas condições clínicas, pode dificultar a aproximação da mãe possa com ele. Mathelin (1997) afirma que o que se encontra ameaçado nos nascimentos ocorridos na urgência é o investimento libidinal no bebê. É muito importante considerar que nesses nascimentos o saber da mãe, esse saber que lhe vem de seu amor, não será, pelo menos num primeiro momento, aquele que pode salvar a criança. A mãe tem de ceder a um outro saber, ao saber do médico.

Chaumon (2006) afirma que o fracasso do amor deixa a mãe confrontada à violência do sexual pulsional e ao gozo do Outro. A autora observa que esse fracasso pode efetuar-se já no tempo da gravidez. Consideramos, por exemplo, que o comunicado de um diagnóstico de má-formação do feto durante a gestação pode ser um fator que venha a destituir a mãe narcísicamente, impedindo que ela possa fazer uma antecipação sobre sua criança. Vimos, no capítulo anterior, que as conseqüências para Laura da comunicação do diagnóstico de má-formação do feto durante a gestação e o encadeamento desse acontecimento à presença de um luto familiar relativo à morte do avô materno não foi sem conseqüências para ela. O laço de amor entre ela e seu bebê, no sentido que estamos conferindo a essa paixão amorosa, encontrava-se interditado. $\mathrm{O}$ bebê que ela tinha dado à luz encontrava-se 
aquém de poder constituir-se num pólo positivo das projeções maternas. "Eu sabia que ele não seria como os outros bebês".

Já a análise da angústia de Dora frente à alta de seu bebê permitiu fazer um balanço dos efeitos adversos para a mãe quando a hospitalização do bebê não contempla apropriadamente os sinais que ela emite ao longo desse período de seu embaraço frente a ele. A análise da fala da mãe indicava que sua extrema angústia era deflagrada pelo estranhamento produzido pelos apelos do bebê. Ela não podia se deixar fisgar nesse apelo sem sentir-se em risco. Ela não deixava que ele chorasse e se assustava quando ele fazia barulho e se mexia. Aqui, verificamos que quando o véu do amor se rasga, ocorre que a mãe fica confrontada com a criançacoisa.

\footnotetext{
O horror do real surge repentinamente, não sob a forma imóvel da alteridade enigmática do anjo impassível, mas em sua vertente ativa, ameaçando, imperioso: uma vez que a pulsão exige pressa, ela reivindica o objeto sem a menor consideração pelo outro [...]. A mãe se encontra, então, na posição radical de passividade que é própria à reversão pulsional, o que Lacan destacou através da forma passiva do verbo: "se fazer".[...] O gozo do Outro está lá, imediato, é o horror do vampiro, o seio monstruoso que aspira a mãe inteira e ameaça esvaziá-la de toda sua substância. A angústia surge no momento em que a relação narcísica faz falta e onde o desejo do Outro interroga o sujeito na raiz de seu ser, como objeto a desse desejo (Chaumon, 2006, p.181).
}

No entanto, há situações em que a condição enigmática da criança se reverte num esforço dos pais em fazer prevalecer seu saber sobre a criança em face ao domínio do saber médico. Esse aspecto é de grande relevância no que respeita a posição da equipe na relação com os pais, pois a equipe é objeto de múltiplas transferências. Verificamos que, freqüentemente, esse aspecto não é levado em consideração e apropriadamente manejado. Há uma expectativa, pelo lado da 
equipe, de que o fornecimento justo das informações clínicas a respeito da evolução do bebê ou das decisões relativas à terapêutica adotada com a criança pode impedir que o mal entendido faça sua irrupção no diálogo com os pais. Sabemos que o mal entendido é a regra, e não a exceção, da comunicação humana, pois aquilo que os pais ouvem sofre o filtro de seus desejos e fantasias inconscientes.

\section{Saber Parental versus Saber Médico}

O primeiro contato realizado com Paula ocorre já passado algum tempo da chegada de seu bebê à unidade de tratamento intensivo neonatal. Ele havia sido deslocado para a sala de tratamento semi-intensivo há cerca de cinco dias.

Ela relata que havia feito seu exame pré-natal nesse mesmo hospital, já que sua obstetra pertence ao quadro médico da instituição. Ela pensava que o nascimento prematuro de seu bebê havia ocorrido devido ao abalo emocional sofrido por ela quando se encontrava na $24^{a}$ semana de gestação relacionado a problemas de saúde na família. Após esse episódio ela passou a ter dores nas costas e no abdômen. Foi, então, recomendado um repouso, já que ela passou a apresentar contrações regulares. Esse repouso se prolongou até a $34^{\mathrm{a}}$ semana de gestação, quando então ela entrou em trabalho de parto. Durante o repouso, diz só ter pensado em poder segurar a gestação o mais longe possível, para que seu bebê pudesse estar mais bem formado.

A gravidez não foi planejada, mas Paula afirma que o bebê foi muito desejado. Ela pretendia concluir seus estudos para depois casar e ter filhos. A 
família deu todo apoio à gravidez desde o início. O marido trabalha durante o dia e faz um curso superior de noite. Em função das condições de risco de sua gestação, decidiram morar na casa dos pais dela. O pai de Paula trabalha na área das ciências humanas e sua mãe está realizando uma formação acadêmica na área de saúde. Segundo ela, esse teria sido um velho sonho da mãe que decidiu investir no sonho após a criação dos filhos. Paula informa que possui uma irmã que é também formada na área da saúde e que ela mesma havia tido contato com essa área durante dois anos. Ela decidiu, após o início do contato com a rotina hospitalar, que esta área não seria uma boa escolha para ela porque se atormentava muito com o sofrimento das pessoas: "Não suportava ver o sofrimento, as desigualdades sociais do atendimento dispensado pelo SUS, enfim as diferenças". Nessa ocasião, buscou uma ajuda psicoterápica que, segundo ela, Ihe apontou o caminho para poder auxiliar as pessoas de outro modo. A psicoterapia foi interrompida no início da gestação por causa do desconforto dos enjôos. Paula comenta, que teria sido melhor que ela não a tivesse interrompido: "Talvez tivesse sido melhor prosseguir, isto me poderia ter ajudado, já que fico nervosa com facilidade".

Paula descobriu a gravidez no segundo mês de gestação. Como tem ovário policístico, era bastante freqüente ficar sem menstruar por dois meses. Além do mais, diziam que ela não engravidaria facilmente. Durante a gestação, gostava muito de fazer ultra-sonografia para ver o bebê. Paula teve que ser submetida a uma cesárea de urgência, mas afirmou que estava advertida da possibilidade do nascimento prematuro de seu bebê. Ela achava que estava preparada para esse nascimento, pois o bebê inclusive tinha bom peso, 2,125 Kg. 
O encontro com o bebê após o nascimento foi, no entanto, bastante traumático para ela, pois ele necessitou do auxílio dos aparelhos para respirar, tendo sido, portanto, entubado. Ela declara que: "Não estava preparada para aquilo". Quando teve alta e foi para casa, não conseguia dormir nem comer. Solicitava que sua mãe ligasse para o hospital todas as noites para que ela pudesse dormir. Ela assim descreve como se portou no primeiro contato com o médico após o nascimento de seu filho: "O médico veio dar-me notícia sobre o estado clínico de meu filho, mas eu procurava não prestar muita atenção ao que ele Ihe dizia, já que por não ser uma leiga na área da saúde encontrava-me apta a entender a gravidade da situação. Preferi confiar e apostar que tudo ia dar certo". Essa costumava ser sua conduta que contrastava com a do marido, que segundo ela, perguntava tudo, queria saber de tudo. Ela considerava-o inclusive bastante ciumento em relação ao bebê. Ficava incomodado com o fato de as enfermeiras o tocarem muito e às vezes achava que elas eram um pouco abruptas com a criança. Ela relata que um dia, quando chegou junto com seu marido na unidade e viram vários residentes no serviço este comentou: "Eles não vão pegar no nosso bebê, não é?".

Paula acha que o bebê está evoluindo bem, pois já necessita de pouco oxigênio e agora precisa ganhar peso. Os familiares estão muito ansiosos, mas ela entende que o bebê tem um outro ritmo para crescer, engordar e para se recuperar. Ela acha que são cansativas as idas e vindas ao serviço: "Aqui, parece que o tempo pára". Ela costuma conversar com outras mães, principalmente com a mãe do bebê que fica no berço vizinho ao do seu filho. 
Os contatos com Paula foram interrompidos devido à transferência repentina de seu bebê para outro hospital logo após nosso último encontro. Tomo conhecimento de que no final de semana havia ocorrido um atrito importante entre Paula e uma das médicas de plantão. De acordo com o relato da equipe, a irmãmédica de Paula havia entrado em contato com o serviço e questionado um aspecto da conduta médica (a utilização de determinado medicamento) adotada com o sobrinho. A equipe argumentou junto à irmã-médica e à avó materna que a conduta adotada era a correta e alegaram que não havia motivo para inquietação em relação à avaliação clínica da criança. No contato feito pela mãe de Paula com a equipe, ela informa a um dos membros da equipe que estava preocupada com sua filha que não vinha se alimentando bem e manifestando preocupações de ter tido o corpo deformado pela gravidez e pelo parto.

Na tentativa de talvez colocar um ponto final no mal-entendido entre a família e a equipe médica, Paula é abordada por outro membro da equipe que reafirma o infundado do questionamento da conduta adotada em relação a seu bebê. Paula fica muito contrariada por ter sido abordada enquanto estava amamentado seu filho e reage imediatamente ao fato de que sua irmã estivesse sendo questionada. Todo o episódio é encerrado com a transferência do bebê para outro hospital. A avó, posteriormente, comunica à equipe que o problema não foi a decisão sobre a conduta terapêutica com 0 bebê, mas a posição da equipe em relação ao questionamento feito pela família.

Inicialmente, vale destacar a reação da mãe ao nascimento do bebê. Ela imaginava que enfrentaria com mais tranqüilidade esse nascimento porque havia 
sido preparada para essa possibilidade. Essa suposição é bastante comum entre as mães que, durante o acompanhamento pré-natal, foram advertidas para a eventualidade maior ou menor de um nascimento prematuro. No entanto, nenhuma delas está preparada verdadeiramente para isso. A presença da criança real, com todo o impacto causado pela impressão de sua enorme fragilidade, desarticula esse suposto saber prévio da mãe. A imagem da criança, conectada ao aparato das máquinas, é sempre inquietante para os pais. Para essa mãe, contudo, o fato de ela possuir uma familiaridade com a área médica faz com que ela se sinta ainda mais em risco quando interpelada pelas informações médicas. Sua posição diante dos informes médicos é a de não prestar muita atenção a nada, de não querer saber. Ela deixa isso para outros: o marido e a mãe. Ela havia decidido interromper a formação iniciada na área da saúde porque não suportava a falta de solução para o sofrimento humano, que é identificado em sua fala pelo desamparo do pessoal do SUS. A sua posição deixa claro a relação significativa entre não querer saber, a falta de solução para o desamparo humano e a angústia suscitada pela falta de resposta ao desamparo.

Vale observar, que Paula destaca que a conduta do marido é mais agressiva e ciumenta em relação ao bebê. Ele não apenas quer saber de tudo, como também sua conduta ciumenta em relação ao bebê, tanto no que se refere à equipe médica, como com relação à enfermagem aponta o que alguns identificam como um traço pelo qual o pai vem tentar marcar seu lugar junto à equipe médica. Mathelin (1997), afirma que a reação, às vezes, mais impetuosa do pai junto à equipe é seu modo de reagir aos efeitos do nascimento de seu filho, tentando recuperar o lugar de terceiro 
junto à mãe e ao bebê que a hospitalização da criança faz deslizar para a equipe médica.

[...] o pai pode mostrar-se muito exigente com a equipe, como se só pudesse vir em ajuda da mãe e do filho de um modo vindicativo. [...] Ele está protegendo sua família; ao opor-se a nós, ao se mostrar intratável, pensa dar novamente a sua mulher, a seu bebê e a si mesmo um pouco de confiança nele (Mathelin, 1997, p.76).

O atrito entre a equipe médica e a família materna é um ponto importante na hospitalização desse bebê. Nos pareceu que a interferência da família materna através do questionamento da conduta médica adotada pela equipe com o bebê pela irmã-médica de Paula foi tomada pela equipe como expressão de uma rivalidade entre pares. Entendemos, entretanto, que a situação armada por esse questionamento tinha como pivô um antagonismo entre o saber que se inscrevia pelo lado materno e o saber da equipe médica. Ao final de todo episódio, a avó materna do bebê assegura à equipe que o problema não foi a decisão sobre a terapêutica em si mesma, mas a reação ao questionamento. O bebê, afinal de contas, informou a avó materna a um dos membros da equipe, estava sendo tratado no outro hospital com a mesma terapêutica.

A compreensão pela equipe das transferências que os pais realizam sobre ela é de vital importância na jornada da hospitalização do bebê. Lembremos que Paula encontrava-se bastante fragilizada após o nascimento de seu filho. Havia as preocupações com o corpo, a falta de apetite e a dificuldade no sono. Ela elide inicialmente tudo que possa remetê-la às más notícias. Ao apoio que ela recebe do marido se interpõe, de maneira importante, o apoio que ela vai buscar do lado da linhagem materna. A mãe liga todas as noites para a UTI para recolher notícias 
sobre o bebê, enquanto a irmã legitima para ela as condutas terapêuticas realizadas com seu filho. O que esta mãe interpreta como uma banalização do questionamento realizado pela irmã torna intolerável toda a situação para ela, pois representa uma destituição do saber sobre o bebê que vem do lado materno. Essa mãe que buscava do lado de sua própria mãe um ancoramento para seu narcisismo abalado pelo nascimento do bebê, utilizou o confronto com a equipe médica para proceder à evasão da criança da cena.

\section{A PRESENÇA ENIGMÁTICA DO BEBÊ PARA A MÃE}

Conheço Kátia quando ela está junto à incubadora de seu filho. Ela diz que ele não gosta que ela pegue em sua mão, mas já disse a ele que quando ele crescer "eu vou passear de mãos dadas com ele no shopping".

Kátia teve uma gestação um pouco difícil, pois desde o seu nascimento é muito alérgica. Ela tem uma dermatite importante e alergia das vias respiratórias. Relata que foi necessário suspender, durante a gestação, a utilização dos medicamentos de rotina (uso tópico e oral). Kátia inclui essa medida nas várias renúncias que teve que realizar para levar a gestação adiante. Precisou também interromper a prática de exercícios pesados de que gosta, bem como parar de dirigir e usar seus cremes. A situação de dependência de outros durante a gestação foi bastante difícil para ela. Havia também uma preocupação com o momento do parto, devido à utilização de analgésicos. Por outro lado, restava a expectativa de saber se seu filho também nasceria alérgico como ela. Para ela, foi "uma benção ele não ter 
precisado de aparelhos para respirar". Além disso, ele nasceu no dia em que ela e o marido faziam onze meses de casados.

Kátia é bastante receptiva ao convite para falar sobre esse nascimento. Ela informa que faz terapia e que seu maior problema no momento é que "quero tudo para ontem. Sou muito ansiosa. Tenho que aprender a ter paciência".

Ela ainda não tem clareza sobre o que realmente precipitou o nascimento prematuro do filho. Quando estava no $3^{\circ}$ mês de gestação, os exames de rotina registraram um processo de envelhecimento da placenta, embora os demais exames estivessem normais. Há a hipótese de que o cordão enrolado em volta do pescoço do bebê possa ter comprometido a circulação adequada do fluxo de oxigênio. Ela pretende, quando estiver menos apurada, poder conversar com seu médico para entender o que pode ter ocorrido. O bebê nasceu no oitavo mês de gestação.

Para Kátia, é muito penoso ir para casa sem seu bebê. Diz que está muito chorosa e que a família também tem estado chorosa junto com ela. O nascimento de seu filho não se parece em nada "com a propaganda do Parmalat, em que a mãe vai com o bebê para a casa, um bebê gordinho e o pai ao lado carregando a sacola". Ela diz: "estou decepcionada com a situação toda". Sabe que não pode levar seu filho para casa, pois os cuidados que ela pode dar não são suficientes para ele.

A participação de Kátia na rotina de tratamento de seu bebê tem sido bastante conturbada. Ela reage a explicações que considera incompletas sobre os procedimentos adotados com seu filho. "Não sou resignada como as mães do SUS 
que aceitam tudo que fazem com seus filhos sem nenhum questionamento". Diz que quando vai fazer um exame de rotina deseja ser informada de tudo. Como seu filho ainda não pode fazer isso, cabe a ela fazer em seu lugar. "Tenho que pedir explicações". Ela quer saber tudo o que se faz com ele. Dá como exemplo o que teria ocorrido ontem: O braço do filho estava picado e ela indagou o que havia sido feito e a resposta foi: "Exame de rotina, mãe". Ela quer saber o que é exame de rotina e para que serve. Ela descreve outra situação em relação à introdução da alimentação por via de uma sonda. Ela pergunta por que seu filho precisa disso. A enfermagem esclarece que ele havia perdido um pouco de peso e ela retruca que ele tem de mamar. A enfermagem tenta explicar a ela que os prematuros precisam de um tempo para aprender a sucção. Ela diz para mim: "Eu não sei nada sobre um prematuro. Tenho sobrinhos, mas nenhum nasceu de 34 semanas".

A conversa que ela e o marido tiveram, posteriormente, com um médico da equipe parece tê-la acalmado um pouco. O médico sanou várias dúvidas sobre os procedimentos de rotina, sobre os exames e sobre o desenvolvimento do bebê. De qualquer modo, Kátia realizou uma divisão de tarefas com o marido. Este ficaria encarregado de conversar com os médicos, enquanto ela se ocuparia de cuidar do filho. Achou que fosse melhor assim, por ser muito impaciente e às vezes parecer "aos olhos dos outros, arrogante". O bebê, por sua vez, teria que fazer a parte dele. "Ele tem que ganhar peso, eu não posso cobrar isso dele, pois ele tem seu ritmo". Pedro, o bebê, não veio para unir o casal, mas para somar segundo a mãe. Ela tem planos de ter outro filho e já disse a Pedro que ele não vai ser filho único, ele vai ter irmão. 
Vemos que há também aqui uma tensão entre a mãe e a equipe que se arma de um modo diferente. Nesse caso, há pelo lado da mãe, de saída, uma enorme dificuldade em consentir que a equipe se interponha entre ela e o bebê. Ela diz ser muito impaciente, não ser submissa como as mães do SUS que nada questionam, ela tem que reivindicar explicações, já que o bebê não pode fazê-lo e por tudo isso "pareço às vezes arrogante aos olhos dos outros". A resistência oferecida pela mãe à equipe não é sem incômodo. Ao lado da conduta mais barulhenta da mãe, há, no entanto um outro aspecto menos perceptível para a equipe.

Houve, ao longo de toda a gestação, uma ansiedade de Kátia em relação ao momento do parto por ser alérgica. Ela se preocupava também se o bebê nasceria como ela: "Foi uma benção ele não ter precisado de aparelhos". No entanto, a situação como um todo é uma decepção para ela. A primeira coisa que ela me diz quando dela me aproximo na incubadora é que seu filho não gosta de dar a mão a ela. Ele não nasce alérgico como ela, porém ele é um bebê prematuro, diferente de todas as crianças de sua família. Ela não sabe o que é um prematuro. "Por que ele não pode mamar?"; "Por que tantos exames?"; "Por que ele está com o braço picado?".

Kátia reconhece, ainda que contrariada e decepcionada, que os cuidados que ela pode dar ao bebê não são suficientes para ele nesse momento. Nos parece que com as enfermeiras ela tolera um pouco melhor o conjunto da situação, pois através do que ela vai recolhendo delas que lidam o tempo todo com ele, vai se constituindo um certo lugar para a mãe junto ao bebê. Ela quer saber se ele dormiu bem à noite, se ele chorou quando ela estava ausente, indaga sobre detalhes da conduta de 
rotina, etc. A decisão da divisão de tarefas entre ela e o marido confere um certo equilíbrio à situação.

Podemos verificar que para essa mãe o nascimento de seu filho impôs um limite insuportável a ela, que vê, de uma hora para outra, seu saber totalmente desvalidado nessa situação. Observamos que ela deixa entrever que as renúncias requeridas para sustentar a gestação não passaram em branco, pois diz que a situação de dependência é muito desconfortável para ela. Ela faz tantas renúncias, e encontra uma criança que desafia seu já sabido, ou seja, ela tem que se deixar fabricar por esse bebê diferente. Ela afirma que o bebê tem que fazer a parte dele, mas é interessante notar que ela já anuncia o próximo filho, quando ela ainda está às voltas com o que ela ainda não pode decifrar dessa criança. Nos parece que, para essa mãe, o nascimento prematuro de seu bebê constituiu uma dura prova para a sua certeza de que a presença de um filho viria somar e não descompletar o que havia antes, em outras palavras, a de que a presença da criança divide a mãe. Para que o laço de amor ganhe a cena é necessário que a mãe consinta em ser o sujeito da falta, pois é ela que está de saída, na condição de desejante na relação com o bebê. Consideramos que para essa mãe a ferida narcísica gerada por esse nascimento que a obrigou a declinar de sua onipotência e a consentir que outros dispusessem de um saber que a ela faltava, constituiu um limite intolerável da situação. Embora seu filho não fosse um prematuro que requisitou procedimentos muito invasivos para a mãe, aquele nascimento gerou uma ferida difícil de cicatrizar naquele momento. O sentimento de insuficiência que essa mãe experimenta com seu bebê indica que em alguns momentos e para algumas mães o nascimento de uma criança prematura vem transtornar a disposição do campo do amor no qual vai 
se realizar esse encontro único e decisivo para a estruturação do sujeito na criança. É necessário possibilitar que a mãe ultrapasse esse ponto de angústia na relação com a criança, de modo a que o laço de amor possa cumprir sua obra, a produção de uma subjetividade. 


\section{CONSIDERAÇõES FinaIS}

Para a psicanálise, a prematuridade que caracteriza o filhote do homem após o nascimento confere ao laço de dependência com o semelhante no início da vida um estatuto de urgência, uma vez que o que está em jogo para ele é a questão de sua sobrevivência. A autonomia é, no início da vida, mortal para o recém-nascido, visto que ele é impotente para realizar a ação específica que vem apaziguar as tensões que transbordam o organismo quando são deflagradas as exigências das necessidades vitais, pois o mecanismo da fuga ao estímulo é inoperante no caso das excitações oriundas do corpo. A atenção do próximo prestativo (Nebensmench), expressão cunhada por Freud no texto Projeto para uma psicologia científica para designar o semelhante que acolhe e trabalha o mal-estar do neonato, é mobilizada pelo estado de desamparo que marca a condição de chegada ao mundo da cria humana. A função do próximo prestativo bem descreve a função materna junto ao bebê quando destaca que seu estado de desamparo nela deflagra uma urgência que a leva a tomar as manifestações orgânicas como mensagens que a interpelam e às quais ela confere um sentido que direciona os cuidados que vão proporcionar a ele um retorno ao estado de repouso. A mãe transforma o grito em apelo e lê nas manifestações do organismo o endereçamento de uma demanda à qual ela responde, fazendo-se instrumento da ação específica que vai promover a experiência de satisfação no recém-nascido.

O remanejamento dos limites da vida pela ciência, graças ao avanço das tecnologias de reanimação, introduz no contexto dos nascimentos novas 
possibilidades em relação à estimativa de sobrevivência dos bebês, mas também novos desafios em relação às condições de acolhimento e subjetivação da vida humana. Para a psicanálise, há uma desarmonia que é constitutiva à condição do homem como ser de desejo, uma vez que essa condição encontra-se ligada à falta de um saber que possa unir sem resíduo o sujeito a seu ser sexuado, daí que o mal-estar é uma dimensão do destino do falante como ser de desejo. Há um impossível estrutural que objeta a simbolização por inteiro do real, já que a distância entre o sujeito e o Outro é incomensurável. Esse incomensurável é atualizado em todo nascimento, pois há uma discordância constitutiva entre o bebê imaginário e o bebê real para os pais. No entanto, o recém-nascido é capturado no investimento narcísico de seus pais, e deste modo, é colocado no lugar do seu ideal. Na clínica do bebê pré-termo, entretanto, esse incomensurável comparece promovendo uma fratura dolorosa no narcisismo dos pais, uma vez que a fragilidade do bebê não os autoriza a se reconhecer, de saída, numa criança cuja existência e sobrevivência está marcada por uma suspensão, por um limiar a ser franqueado. A construção do olhar dos pais para seu filho, - olhar que atualiza o investimento desejante que suporta os laços de amor - sofre o impacto da medicalização desse nascimento, pois eles precisam transpor a barreira do saber médico para encontrar o caminho de endereçamento a seu bebê. $O$ sentido adquirido pela hospitalização da criança é capital nesse momento, pois a constituição do sujeito do desejo não reside nas condições de seu organismo, daí o risco permanente de que a criança se perca no saber médico.

A urgência que acompanha os nascimentos prematuros redobra os efeitos do traumatismo do nascimento, visto que os pais são confrontados com 
a incerteza dolorosa em relação à sobrevivência da criança e à eventual presença de seqüelas da prematuridade clínica. Para os pais dos bebês prematuros as manifestações e as necessidades de seu filho não são legíveis de imediato para eles, uma vez que há uma inquietante estranheza despertada pelo seu filho que atualiza não apenas o desconhecido, mas o incognoscível, quer dizer, o ponto em que se desvela o limite do simbólico. Ansermet (2003), a esse respeito, afirma que a clínica dos nascimentos de risco abarca o campo dos fenômenos que não se deixam apreender pela linguagem, tais como os fenômenos psicossomáticos e as questões que presidem o nascimento do sujeito. A separação, imposta pela hospitalização em face dos cuidados requeridos para o tratamento, desloca, de saída, o lugar e o saber dos pais junto a seu filho pelos dispositivos que sustentam o ato médico. Um nascimento é, para a psicanálise, um acontecimento que é sempre portador de um traumatismo, já que ele atualiza a dimensão enigmática da origem para um sujeito, isto é, a passagem do não ser ao ser. O nascimento excede o saber da biologia sobre a reprodução, o saber genético e a história familiar, na medida em que a criança nunca é apenas continuidade do que já existia. Nos nascimentos prematuros a tensão entre a vida e a morte afeta a construção da parentalidade, uma vez que o bebê também constrói seus pais.

O desamparo parental deflagrado pelo nascimento aponta para a importância da intervenção pela palavra nesse momento, pois a urgência nos nascimentos também é uma urgência de palavras, na medida em que é pela linguagem que o ser humano vai subjetivar as questões de sua existência. Na clínica do bebê pré-termo a separação imposta pela hospitalização ecoa para 
os pais como uma ruptura psíquica com seu filho, enquanto que para o bebê essa ruptura instala uma descontinuidade entre suas experiências pré e pósnatais. Nesse caso, está em jogo tanto salvar o organismo em perigo como o desejo dos pais que anima o nascimento do sujeito para a vida simbólica. Aqui, mais ainda, verificamos que o momento do parto não é um fim, mas um começo, pois a saída do bebê do limbo requer a presença de um Outro que possa convocá-lo à vida.

A implantação na vida simbólica para o humano envolve a dimensão de um ato, um ato inaugural, visto que é necessário um ato para haver um começo. E o começo, a partida, para o ser falante é dada no e pelo Outro, pois o sujeito não é causa de si mesmo, visto que o simbólico o antecede. A vida é, antes de tudo, um dom, um dom de amor, que o futuro sujeito recebe de um Outro, pois a transmissão que a assegura está alicerçada num registro que não é coincidente com o da satisfação das necessidades, mas é solidária ao amor e ao desejo. Os pais, primeiros representantes do Outro (simbólico) para o sujeito, realizam um trabalho de artesãos, uma vez que eles oferecem os significantes com os quais o sujeito pode se representar. É necessário que os pais do bebê pré-termo possam se iludir com alguma promessa em relação a seu filho, de modo a que eles possam antecipar o que ainda não existe. A função do amor dos pais é essa: criar, ver, sonhar, antecipar o que ainda não existe. O amor dos pais preside essa criação. Freud apontou que o olhar amoroso dos pais para a criança é um re-nascimento vigoroso de seu narcisismo infantil e que esse olhar coroa o bebê com todos os atributos de perfeição. 
Na clínica do bebê pré-termo os dispositivos de acolhimento devem zelar para que a hospitalização do bebê não adquira o sentido de uma devastação do sujeito. Para que tal objetivo seja alcançado impõe-se a necessidade de preservar as coordenadas simbólicas do bebê, visto que ele não pode se constituir sozinho. A abertura positiva das unidades de tratamento intensivo neonatal com vistas a promover maior participação dos pais no tratamento de seus filhos exige a construção de lugares de escuta que permitam situar os desdobramentos dessa abertura, uma vez que o acesso irrestrito dos pais a seu filho não garante que eles efetivamente encontrem o lugar que lhes é devido junto a ele. A humanização dos cuidados na clínica do bebê pré-termo possibilita que algo do real desses nascimentos possa se inscrever para os pais, passo necessário para que eles se autorizem a avançar menos timidamente e menos intimidados pelos dispositivos médicos num contato mais vivo com seu filho. A palavra humaniza o sofrimento e reanima o bebê no desejo dos pais criando assim a possibilidade para este de um espaço psíquico em seus pais. A experiência recolhida na escuta da clínica do bebê pré-termo apontou para a relevância de um olhar mais atento ao que se passa nos tempos da estruturação precoce do sujeito, visto que a clínica do bebê é uma clínica que se desenrola na perspectiva da construção, isto é, que tem como direção ética promover a subjetivação do bebê pelos seus cuidadores primordiais. Concordamos com Fernandes (2006) quando afirma que na clínica da primeira infância é necessário manter o vigor da dimensão do enigma, do apelo, da surpresa e do olhar interessado para o bebê como prerrogativas a 
serem cumpridas por aqueles que se dispõem a trabalhar no limiar de entrada do sujeito na vida simbólica.

A construção de uma interlocução profícua entre a psicanálise e a medicina vem sendo permanentemente problematizada por vários profissionais que atuam no campo da intervenção na primeira infância, uma vez que a intervenção oportuna pode permitir o bom encontro entre o bebê e seus outros. Para Winnicott, por exemplo, o pediatra tem a oportunidade única de testemunhar detalhes preciosos da construção do laço mãe-bebê e este deveria, portanto conhecer os sinais de sofrimento que por vezes se manifestam de modo sutil. Françoise Dolto por outro lado, apostava na escuta rigorosa da criança como sujeito do desejo e afirmava que a palavra humaniza o sofrimento, visto que o sofrimento humano é antes de tudo uma conseqüência do vazio de palavra que se traduz em feridas e lacunas na história de um sujeito. Quando pensamos em auxiliar os pais e os bebês em sofrimento temos que partir do fato de que não há de um lado o bebê e de outro seus pais, mas que há ou não o encontro, o laço, o jogo, o lúdico, o infantil. A tarefa do bebê é tripla: aceder à realidade, à integração e ao sentido do corpo. No entanto, ele não pode fazer isto sozinho, pois depende, por exemplo, de sua parceira, a mãe, para avançar nesse trabalho fundamental de construção de seu ser no mundo. No caso do bebê pré-termo, seus parceiros são também a equipe terapêutica que ocupa um lugar fundamental no cumprimento dessas tarefas durante a jornada de sua hospitalização. Os cuidados de reanimação inscrevem os acontecimentos perinatais no corpo e estes acontecimentos vão se encadear a tudo aquilo que presidiu a chegada da 
criança no mundo: os acontecimentos que marcaram sua concepção, a gravidez, seu nascimento, etc.

O psicanalista está comprometido com a escuta do sujeito e as manifestações de sua dor de existir. A constituição dos laços de trabalho que possibilitam alcançar as novas formas de expressão do sofrimento humano que advém com o avanço da presença da ciência na contemporaneidade é de capital importância, visto que esse avanço traz novas questões para a subjetivação do humano. A humanização dos cuidados que acolhem a criança hospitalizada nos serviços de medicina, como ocorre nas unidades de tratamento intensivo neonatal, inaugura uma condição inteiramente nova para a equipe terapêutica, a saber: trabalhar exposta ao olhar dos pais e aos seus questionamentos. Uma reflexão sobre a atuação cotidiana no limite entre vida e morte seria profícua tanto para a equipe terapêutica como para o psicanalista, já que os avanços das tecnologias de reanimação atualizam cada vez de maneira mais potente a tensão entre os esforços para salvar o organismo sem negligenciar a dimensão do sujeito.

Acreditamos que poder circunscrever as questões que interrogam o desejo que sustenta o ato clínico da equipe terapêutica não seria de menor relevância para demarcar o alcance e os limites do trabalho de reanimação. A escuta do psicanalista, por sua vez, encontra-se também comprometida com o desejo, pois o desejo do analista orienta sua práxis na direção da ética da psicanálise. Para Lacan o desejo do analista é um desejo advertido, uma vez que o psicanalista sabe que não há bem supremo que possa trazer a felicidade 
integral. Nesse sentido, o acolhimento do sofrimento humano para a psicanálise inclui a condição incontornável do impossível que é constitutivo ao mal-estar do ser falante. Nessa perspectiva, a inclusão da morte pelo psicanalista no contexto das práticas médicas que se situam no limiar sutil e ao mesmo tempo decisivo em relação à aposta na vida, essa segunda morte à qual nossa humanidade deve sua realização, é uma aposta na qual reside a chance para que a dimensão do sujeito não seja elidida e aspirada por um saber que se pretende validar de maneira universal. 


\section{REFERÊNCIAS*}

ANDRÉ, S. O que quer uma mulher? Rio de Janeiro: Jorge Zahar, 1987. 295 p.

AGAMBEN, G. O poder soberano e a vida nua I. 2. ed. Belo Horizonte: UFMG, 2007. 207 p.

ARENDT, H. Origens do Totalitarismo. 5. ed. São Paulo: Companhia das letras, 1989. $562 \mathrm{p}$.

ARIÈS, P. História Social da Criança e da Família. 2. ed. Rio de Janeiro: Guanabara, 1986. 279 p.

ANSERMET, F. Clínica da origem: a criança entre a medicina e a psicanálise. Rio de Janeiro: Contra-Capa, 2003. 223 p.

BERGÈS, J.; BALBO, G. A criança e a Psicanálise. Porto Alegre: Artes Médicas, 1997. 262 p.

. A Atualidade das teorias sexuais infantis. Porto Alegre: CMC, 2001. 174 p.

. Jogo de posições da mãe e da criança: ensaio sobre o transitivismo. Porto Alegre: CMC, 2002. 160 p.

Do corpo à letra In: Vorcaro, A. (Org). Quem fala na língua? Salvador: Àgalma, 2004a. p. 151-174.

. A língua nos causa. In: Vorcaro, A. (Org). Quem fala na língua? Salvador: Àgalma, 2004b. p. 123-150.

BERNARDINO, L.M.F. A abordagem psicanalítica do desenvolvimento infantil e suas vicissitudes. In: Bernardino, L.M.F (Org). O que a psicanálise ensina sobre o sujeito em constituição. São Paulo: Escuta, 2006. p. 19-41.

\footnotetext{
* De acordo com: Associação Brasileira de Normas Técnicas - NBR 10520, 2002.
} 
BLEICHMAR, S. As condições de humanização. In: Melgaço, R.G. (Org). A Ética na Atenção do Bebê: Psicanálise-Saúde-Educação. São Paulo: Casa do Psicólogo, 2006. p. 15-23.

CHARPAK, N.; CALUME, F.Z.; HAMEL, A. O método Canguru. Rio de Janeiro: Mc Graw Hill, 1999. 124 p.

CHATEL, M-M. Mal estar na Procriação, as mulheres e a medicina da procriação. Rio de Janeiro: Campo Matêmico. 1995. 143 p.

CHAUMONN, F. Loucuras Maternas. Revista Literal. Escola de Psicanálise de Campinas, Campinas/São Paulo, A criança e o infantil na clínica psicanalítica, n. 9, p. 163-182, 2006.

CORIAT, E. Psicanálise e clínica com bebês. Porto Alegre: Artes e Ofício, 1997. 310 p.

COURONNE, M. O prematuro: um bebê inteiro à parte. In: Busnel, M.C. (Org). A linguagem dos bebês. Sabemos escutá-los? São Paulo: Escuta, 1997. p. 136-145.

CRESPIN, G.C. A clínica precoce: o nascimento do humano. Coleção Primeira Infância. Dirigida por Claudia Mascarenhas. São Paulo: Casa do Psicólogo, 2004. $187 \mathrm{p}$.

DIAS, M.M. A explosão da infância. Revista Literal da Escola de Psicanálise de Campinas, Campinas/São Paulo, n.10, p.185-193, 2007.

DOLTO, F. Elementos para uma história: depoimento. [abril de 1986]. In: Cifalli, M. (Org). Seguindo os passos de Françoise Dolto. Campinas: Papirus,1989. Entrevista concedida a Elisabeth Roudinesco. p. 37-46.

. Quando surge a criança. Campinas: Papirus, 1996. 200 p.

DONZELOT, J. A polícia das Famílias. 2. ed. Rio de Janeiro: Graal. 1986. 209 p.

DOR, J. Introdução à leitura de Lacan, o inconsciente estruturado como linguagem Porto Alegre: Artes Médicas, 1989. 203 p. 
Introdução à leitura de Lacan. Porto Alegre: Artes Médicas, 1995. v. 2. 258

p.

DRUON, C. Ajuda ao bebê e aos seus pais em terapia intensiva neonatal In: Wanderley, B.B. (Org). Agora eu era o rei: os entraves da prematuridade. Salvador: Àgalma, 1999. p. 35-54.

DUFOUR, D.R. A Arte De Reduzir As Cabeças. Rio de Janeiro: Companhia de Freud, 2005. 216 p.

ELIADE, M. Nacimiento y Renacimiento. Barcelona: kairós, 2000. 239 p. . Mitos, Sonhos e Mistérios. Lisboa: Edições 70, 2001. 248 p.

FABRE-GRENET, M. Os meios de comunicação do prematuro In: Busnel, M.C. (Org). A linguagem dos bebês. Sabemos escutá-los? São Paulo: Escuta, 1997. p. 111-123.

FERENCZI, S. Confusão de línguas entre os adultos e a criança. In: Obras Completas de Sándor Ferenczi. São Paulo: Martins Fontes, 1992. v. IV. p. 97-106.

FERREIRA, H.B.A. Novo Dicionário Aurélio da Língua Portuguesa. 2. ed. rev. e ampl. Rio de Janeiro: Nova Fronteira, 1986. 1.838 p.

FERREIRA, M.T. Como a palavra é tomada no corpo? Revista Literal da Escola de Psicanálise de Campinas, Campinas/São Paulo, n. 9, p. 33-47, 2006.

FERREIRA, S. A interação Mãe-Bebê: Primeiros Passos In: Wanderley, D.B. (Org). Palavras em torno do berço. Salvador: Ágalma, 1997. p. 77-88.

FINGERMANN, D.; DIAS, M.M. Por causa do pior. São Paulo: Iluminuras, 2006. 174 p.

FREUD, S. (1892-1899) Extratos dos documentados dirigidos a Fliess. 2. ed. Trad. Vera Ribeiro. Rio de Janeiro: Imago, 1987. (Edição Standard Brasileira das Obras Psicológicas Completas de Sigmund Freud). vol. 1 
. (1895) Projeto para uma psicologia científica. Trad. Vera Ribeiro. Rio de Janeiro: Imago, 1987. (Edição Standard Brasileira das Obras Psicológicas Completas de Sigmund Freud). vol.1

. (1905) Três Ensaios sobre a teoria da sexualidade. Trad. Jayme Salomão. Rio de Janeiro: Imago, 1972.(Edição Standard Brasileira das Obras Psicológicas Completas de Sigmund Freud). vol. 7

. (1907) Análise de uma fobia em um menino de cinco anos. Trad. Jayme Salomão. Rio de Janeiro: Imago, 1977.(Edição Standard Brasileira das Obras Psicológicas Completas de Sigmund Freud). vol.10

. (1908) Sobre as teorias sexuais das crianças. Trad. Jayme Salomão. Rio de Janeiro: Imago, 1976. (Edição Standard Brasileira das Obras Psicológicas Completas de Sigmund Freud). vol. 9

(1914) Uma introdução ao Narcisismo. Trad. Jayme Salomão. Rio de Janeiro: Imago, 1974. (Edição Standard Brasileira das Obras Psicológicas Completas de Sigmund Freud). vol. 14

. (1920) Além do princípio do prazer. Trad. Jayme Salomão. Rio de Janeiro: Imago, 1976. (Edição Standard Brasileira das Obras Psicológicas Completas de Sigmund Freud). vol.23

. (1923) A Organização genital infantil. Trad. Jayme Salomão. Rio de Janeiro: Imago, 1976. (Edição Standard Brasileira das Obras Psicológicas Completas de Sigmund Freud). vol. 19

. (1924) A dissolução do complexo de Édipo. Trad. Jayme Salomão. Rio de Janeiro: Imago, 1976. (Edição Standard Brasileira das Obras Psicológicas Completas de Sigmund Freud). vol. 19

. (1925) Algumas conseqüências psíquicas da diferença anatômica entre os sexos. Trad. Jayme Salomão. Rio de Janeiro: Imago, 1976. (Edição Standard Brasileira das Obras Psicológicas Completas de Sigmund Freud). vol. 19

. (1926) Inibição, Sintoma e Angústia. Trad. Jayme Salomão. Rio de Janeiro: Imago, 1976. (Edição Standard Brasileira das Obras Psicológicas Completas de Sigmund Freud). vol. 20 
. (1930) O mal estar na civilização. Trad. Jayme Salomão. Rio de Janeiro: Imago, 1974. (Edição Standard Brasileira das Obras Psicológicas Completas de Sigmund Freud). vol. 21

. (1931) Sexualidade Feminina. Trad. Jayme Salomão. Rio de Janeiro: Imago, 1974. (Edição Standard Brasileira das Obras Psicológicas Completas de Sigmund Freud). vol. 21

. (1933a) Ansiedade e Vida Instintual. Trad. Jayme Salomão. Rio de Janeiro: Imago, 1976. (Edição Standard Brasileira das Obras Psicológicas Completas de Sigmund Freud). vol. 22

. (1933b) Feminilidade. Trad. Jayme Salomão. Rio de Janeiro: Imago, 1976.(Edição Standard Brasileira das Obras Psicológicas Completas de Sigmund Freud). vol. 22

FOUCAULT, M. História da sexualidade: a vontade de saber. 7. ed. Rio de Janeiro: Graal, 1985. v. 1. 152 p.

GOLSE, B. O bebê, seu corpo e sua psique: explorações e promessas de um novo mundo In: Aragão, R.O. (Org). O bebê, o corpo e a linguagem. São Paulo: Casa do Psicólogo, 2004. p. 15-40.

GOMES, H.L.A. As especificidades do vínculo da mãe com o bebê pré-termo na situação de internação. 2001. 119 f. Dissertação (Mestrado em Psicologia) - Instituto de Psicologia, Universidade de São Paulo, São Paulo. 2001.

JERUSALINSKY, A. ET ALS. Psicanálise e desenvolvimento infantil: um enfoque transdisciplinar. Porto Alegre: Artes Médicas, 1989. 205 p.

JULIEN, P. Abandonarás teu pai e tua mãe. Rio de Janeiro: Companhia de Freud, 2000. 93 p.

LACAN, J. (1949). O estádio do espelho como formador da função do eu In: Escritos. Rio de Janeiro: Jorge Zahar, 1998. p. 96-103.

. (1953). Função e campo da fala e da linguagem em psicanálise In: Escritos. Rio de Janeiro: Jorge Zahar, 1998. p. 238-324. 
1985. $366 \mathrm{p}$.

(1955-56). O seminário, Livro 3, As psicoses. Rio de Janeiro: Jorge Zahar, - (1956-57). O seminário, Livro 4, A relação de objeto e as estruturas

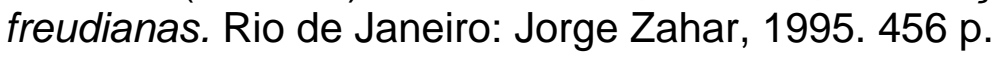

. (1959-60) O Seminário, Livro 7, A ética da psicanálise. Rio de Janeiro: Jorge Zahar, 1988. 396 p.

- (1960) Observação sobre o relatório de Daniel Lagache: Psicanálise e estrutura da personalidade In: Escritos. Rio de Janeiro: Jorge Zahar, 1998. p. 653-691.

. (1960-61) O Seminário, Livro 8, A Transferência. Rio de Janeiro: Jorge Zahar, 1992. 386 p.

. (1962-63) O Seminário, Livro 10, A Angústia. Rio de Janeiro: Jorge Zahar, 2005. 366 p.

- (1964) O Seminário, Livro 11 , Os quatro conceitos fundamentais da psicanálise. Rio de Janeiro: Jorge Zahar, 1979. 269 p.

. (1969) Nota sobre a criança In: Outros Escritos. Rio de Janeiro: Jorge Zahar, 2003. p. 369-370.

. (1969-70) O Seminário 17, O avesso da psicanálise. Rio de Janeiro: Jorge Zahar, 1992. 208 p.

LAJONQUIĖRE, L. A infância do desejo, o desejo de infância. In: Leite, N.V.A. (Org). Corpolinguagem: A estética do desejo. Campinas: Mercado de Letras, 2005. p. 235248.

LAMBOTTE, M. C. Angústia In: KAUFFMAN, P. (Ed.). Dicionário enciclopédico de psicanálise. Rio de Janeiro: Jorge Zahar, 1996. p. 36-44.

LAZNIK-PENOT, C. Os efeitos da palavra sobre o olhar dos pais, fundador do corpo da criança In: Wanderley, D.B. (Org). Agora eu era o rei: os entraves da prematuridade. Salvador: Ágalma, 1999. p. 129-140. 
LEBRUN, J. P. Um Mundo sem Limite: ensaio para uma clínica do social. Rio de Janeiro: Companhia de Freud, 2004. 214 p.

LEITE, N.V. O corpo como receptáculo: anotações. Revista Literal da Escola de Psicanálise, Campinas/São Paulo, n. 9, p. 65-67, 2006.

LEMÉRER, B. Algumas reflexões a partir do texto de Freud sobre as teorias sexuais In: A criança e o saber. Letra Freudiana, Escola, Psicanálise e Transmissão. Rio de Janeiro: Revinter, 1999. p. 13-20.

LÉVI-STRAUSS, C. O feiticeiro e sua magia. 5. ed. In: Antropologia estrutural. Rio de Janeiro: Tempo Brasileiro, 1996. p. 193-213.

LÈVI-STRAUSS, C. A eficácia simbólica. 5. ed. In: Antropologia estrutural. Rio de Janeiro: Tempo Brasileiro, 1996. p. 215-236.

MATHELIN, C. O sorriso da Gioconda: clínica psicanalítica com bebês prematuros. Rio de Janeiro: Companhia de Freud, 1999. 157 p.

MILLER, J.A. A criança entre a mulher e a mãe In: Opção Lacaniana, n.21, abr., 1998. p. 7-12.

MINISTÉRIO DA SAÚDE, SECRETARIA DE POLÍTICAS DE SAÚDE. Atenção Humanizada ao recém-nascido de baixo peso: método mãe-canguru: manual técnico. Brasília: Ministério da Saúde, 2002.282p.

MOTTA, P.P.S. Prevenção em saúde mental - por que não? In: Bernardino, L.M.F.; Rohenkohl, C.M.F. (Org). O bebê e a modernidade: abordagens clínicas. São Paulo: Casa do Psicólogo, 2002. p. 109-116.

POSTMAN, N. O Desaparecimento da Infância. Rio de Janeiro: Graphia, 1999. 190 p.

RODULFO, R. O Brincar e o Significante: um estudo psicanalítico sobre a constituição precoce. Porto Alegre: Artes Médicas, 1990. 179 p.

ROSA, M.D. O lugar da criança e a família na contemporaneidade. Revista Literal da Escola de Psicanálise de Campinas, Campinas/São Paulo, n. 9, p.115-128, 2006. 
ROUSSEAU, P. A memória das crianças pequenas In: Busnel, M.C. (Org.). A linguagem dos bebês: sabemos escutá-los? São Paulo: Escuta, 1997. p. 224-234.

SOLER, C. O que Lacan dizia das mulheres. Rio de Janeiro: Jorge Zahar, 2006. 245 p.

SPITZ, R. El primer año de vida del nino. Versão española de Pedro Barcelo e Luis Fernández Cancela. Madri: Aguillar, 1975. 131 p.

SZEJER, M. Palavras para Nascer: a escuta psicanalítica de bebês em maternidade. São Paulo: Ed. Casa do Psicólogo, 1999. 219 p.

VILTARD, M. Amor. In: KAUFFMAN, P. (Ed.). Dicionário enciclopédico de psicanálise. Rio de Janeiro: Jorge Zahar, 1996. p. 27-35.

VORCARO, A. A criança na clínica psicanalítica. Rio de Janeiro: Companhia de Freud, 1997. 193 p.

. Doenças graves na infância. In: Trata-se uma criança. Rio de Janeiro: Companhia de Freud, 1998. v. 1. p. 333-340.

O corpo na psicose In: Leite, N.V.A. (Org). Corpolinguagem: gestos e afetos. Campinas: Mercado de Letras, 2003. p. 209-231.

WANDERLEY, D.B. A entrada do bebê no mundo da linguagem e sua relação com o outro parental. "Psicanálise e Clínica de bebês" da Associação Psicanalítica de Curitiba, Ano 4, n. 4, p.53-61, dez. 2000.

WILHEIN, J. O que é psicologia pré-natal? 3. ed. rev. e ampl. São Paulo: Casa do Psicólogo, 2002. 126 p.

WINNICOTT, D.W. (1943) Pediatria e Psiquiatria In: Da pediatria à Psicanálise. Rio de Janeiro: Francisco Alves, 1978. p. 287-311.

. (1956a) Pediatria e neurose infantil In: Da pediatria à Psicanálise. Rio de Janeiro: Francisco Alves, 1978. p. 513-520.

. (1956b) Preocupação Materna Primária In: Da pediatria à Psicanálise. Rio de Janeiro: Francisco Alves, 1978. p. 491-498. 
. (1960) Teoria do relacionamento paterno-infantil In: O ambiente e os

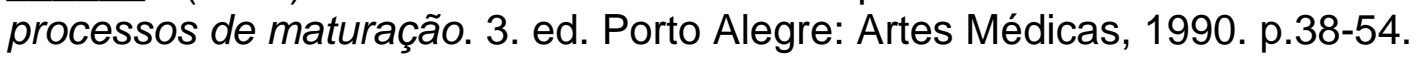

. (1963) Da dependência à independência no desenvolvimento do indivíduo In: O ambiente e os processos de maturação. 3. ed. Porto Alegre: Artes Médicas, 1990. p. 79-87.

. (1967) O papel de espelho da mãe e da família no desenvolvimento infantil In: O brincar e a realidade. Rio de Janeiro: Imago. 1975. p. 153-162. 


\section{BIBLIOGRAFIA CONSULTADA}

AGMAN, M.; DRUON, C.; FRICHT, A. Ajuda ao bebê e aos seus pais em terapia intensiva In: Wanderley, D.B. (Org). Agora eu era o rei: os entraves da prematuridade. Salvador: Àgalma, 1999. p. 35-54.

ARAGÃO, R.O. Narcisismo materno e criação do espaço psíquico para o bebê In. Aragão, R.O. (Org). O bebê, o corpo e a linguagem. São Paulo: Casa do Psicólogo, 2004. p. 91-101.

. De mãe para filha: a transmissão da maternalidade In: Melgaço, G.R. (Org.). A ética na atenção ao bebê. Psicanálise - Saúde - Educação. São Paulo: Casa do Psicólogo, 2006. p. 97-108.

ANZIEU, D. O Eu-Pele. São Paulo: Casa do Psicólogo, 1989. 286 p.

BATHIKA, E.C. As palavras que alimentam a humanização - Reflexões acerca da alimentação - Uma experiência em UTIN. In: Melgaço, G.R. (Org.). A ética na atenção ao bebê. Psicanálise - Saúde - Educação. São Paulo: Casa do Psicólogo, 2006. p. 161-166.

BERNARDINO, L.M.F. Bases psicanalíticas para uma escuta de bebês e seus pais, a partir do seminário sobre "A carta roubada". "Psicanálise e Clínica de bebês" da Associação Psicanalítica de Curitiba, Ano 4, n. 4, p.68-75, dez. 2000.

O desenvolvimento na perspectiva estrutural e a psicanálise. In: Bernardino, L.M.F.;Rohenkohl, C.M.F. (Org). O bebê e a modernidade: abordagens teórico-clínicas. São Paulo: Casa do Psicólogo, 2002. p. 61-64.

Estética e ética na clínica psicanalítica com bebês. In: Melgaço, G.R. (Org.). A ética na atenção ao bebê. Psicanálise - Saúde - Educação. São Paulo: Casa do psicólogo, 2006. p. 79-87.

BLEICHMAR, S. Nas origens do sujeito psíquico, do mito à história. Porto Alegre: Artes Médicas, 1993. 207 p. 
BOUKOBZA, C. CONSTANCE - uma criança resgatada da medicina. In: Melgaço, G.R. (Org.). A ética na atenção ao bebê. Psicanálise - Saúde - Educação. São Paulo: Casa do psicólogo, 2006. p. 25-32.

O desamparo parental perante a chegada do bebê In: Bernardino, L.M.F.;Rohenkohl, C.M.F. (Org). O bebê e a modernidade: abordagens teóricoclínicas. São Paulo: Casa do Psicólogo, 2002. p. 15-25.

BRAZELTON, T.B. O que todo bebê sabe. São Paulo: Martins Fontes, 1992. 290 p.

CABASSU, G. Introdução In: Wanderley, D.B. (Org). Palavras em torno do berço. Salvador: Ágalma, 1997. p. 7-14.

CAMAROTTI, M.C.; SAMPAIO, L. A morte em UTI neonatal: escutando a equipe de saúde. In: Melgaço, G.R. (Org.). A ética na atenção ao bebê.Psicanálise - Saúde Educação. São Paulo: Casa do psicólogo, 2006. p. 149-159.

CARVALHO, V.M.B. Da janela do pediatra In: Melgaço, G.R. (Org.). A ética na atenção ao bebê. Psicanálise - Saúde - Educação. São Paulo: Casa do psicólogo, 2006. p. 205-211.

CATÃO, I. Um lugar de palavras. In: Bernardino, L.M.F.;Rohenkohl, C.M.F. (Org). O bebê e a modernidade: abordagens teórico-clínicas. São Paulo: Casa do Psicólogo, 2002. p. 179-192.

. O bebê tomado ao pé da letra. In: Aragão, R.O. (Org). O bebê, o corpo e a linguagem. São Paulo: Casa do Psicólogo, 2004. p. 129-138.

CHATELARD, D. S. O desejo do psicanalista em antecipação? In: Aragão, R.O. (Org). O bebê, o corpo e a linguagem. São Paulo: Casa do Psicólogo, 2004. p. 129138.

CIFALLI, M.; AUBRY, J. Conversa sobre Françoise Dolto. In: Cifalli, M. (Org). Seguindo os passos de Françoise Dolto. Campinas: Papirus, 1989. p. 37-46.

CLAVREUL, J. A Ordem Médica. São Paulo: Ed. Brasiliense, 1983. 274 p.

COE, C.; LUBACH, G.R.; ERSHLER, W.B. O papel imunológico da mãe In: Busnel, M.C. (Org). A linguagem dos bebês. Sabemos escutá-los? São Paulo: escuta, 1997. p. 63-89. 
CONTÉ, C. O Real e o Sexual de Freud a Lacan. Rio de Janeiro: Jorge Zahar, 1995. $271 \mathrm{p}$.

CRAMER, B. A técnica das terapias breves pais/crianças pequenas. In: Guedeney, A.; Lebovici, S. (Org). Intervenções psicoterápicas pais-bebês. Porto Alegre: Artmed, 1999. p. 91-99.

DEBRAY, R. Os princípios das consultas e das terapias dos bebês com distúrbios somáticos. In: Guedeney, A.; Lebovici, S. (Org). Intervenções psicoterápicas paisbebês. Porto Alegre: Artmed, 1999. p. 57-62.

DIAS, M.M. Moda divina decadência, ensaio psicanalítico. São Paulo: Hacker, 1997.150 p.

DIAS, M. M. A aventura do vir-a-ser: Uma experiência em UTI neonatal. In: Aragão, R.O. (Org). O bebê, o corpo e a linguagem. São Paulo: Casa do Psicólogo, 2004. p. 201-210.

. Uma escuta psicanalítica em neonatologia. In: Melgaço, G.R. (Org.). A ética na atenção ao bebê. Psicanálise - Saúde - Educação. São Paulo: Casa do Psicólogo, 2006. p. 137-147.

. Sublimação feminina e humanização. Revista Literal da Escola de Psicanálise de Campinas, Campinas/São Paulo, n. 10, p. 79-94, 2007.

DRUON, C. Os modos de expressão dos bebês em um serviço de medicina neonatal In: Busnel, M.C. (Org). A linguagem dos bebês. Sabemos escutá-los? São Paulo: Escuta, 1997. p. 124- 135.

FENDRIK, S. Ficção das origens. Porto Alegre: Artes Médicas, 1991. 108 p.

FERNANDES, M.C. A clínica com o bebê e sua ética. In: Melgaço, G.R. (Org.). A ética na atenção ao bebê. Psicanálise - Saúde - Educação. São Paulo: Casa do Psicólogo, 2006. p. 89-94.

FERNANDES, L. R. O olhar do engano: Autismo e o Outro primordial. São Paulo: Escuta, 2000. $166 \mathrm{p}$. 
FREUD, S. (1911) Formulações sobre os dois princípios do funcionamento mental. Trad. Jayme Salomão. Rio de Janeiro: Imago, 1976. (Edição Standard Brasileira das Obras Psicológicas Completas de Sigmund Freud). Vol. 12

. (1915) Os instintos e suas vicissitudes. Trad. Jayme Salomão. Rio de Janeiro: Imago, 1974. (Edição Standard Brasileira das Obras Psicológicas Completas de Sigmund Freud). Vol. 14

. (1918) História de uma neurose infantil. Trad. Jayme Salomão. Rio de Janeiro: Imago, 1976. (Edição Standard Brasileira das Obras Psicológicas Completas de Sigmund Freud). Vol. 17

GOLSE, B. Sobre a Psicoterapia Pais-Bebê: narratividade, filiação e transmissão. São Paulo: Casa do Psicólogo, 2003. 165 p.

HARARI, R. O Seminário a Angústia de Lacan: Uma introdução. Porto Alegre: Artes e Ofício, 1997. 241 p.

JERUSALINSKY, A. Como a linguagem é transmitida? "Psicanálise e Clínica de bebês" da Associação Psicanalítica de Curitiba, Ano 4, n. 4, p. 9-15, dez. 2000.

. O nascimento do ser falante. In: Bernardino, L.M.F.;Rohenkohl, C.M.F. (Org). O bebê e a modernidade: abordagens teórico-clínicas. São Paulo: Casa do Psicólogo, 2002. p. 51-59.

JERUSALINSKY, J. Enquanto o futuro não vem: a psicanálise na clínica interdisciplinar com bebês. Salvador: Àgalma, 2002. 306 p.

JULIEN, P. A Feminilidade Velada, aliança conjugal e modernidade. Rio de Janeiro: Companhia de Freud, 1997. 102 p.

LACAN, J. (1953-54). O Seminário, Livro 1, Os escritos técnicos de Freud. Rio de Janeiro: Jorge Zahar, 1979. $336 \mathrm{p}$.

- (1957-58) O Seminário, Livro 5, As Formações do Inconsciente. Rio de Janeiro: Jorge Zahar, 1999. 531 p.

. (1966) Psicanálise e Medicina. Boletim do Recorte. Órgão de difusão interna do Recorte de Psicanálise, v. 6, n. 9, p. 3-12, jun. 1996. 
1998. p. 653-691.

(1966) A ciência e a verdade In: Os escritos. Rio de Janeiro: Jorge Zahar,

LAZNIK-PENOT, M.C. Do fracasso da instauração da imagem do corpo ao fracasso da instauração do circuito pulsional - Quando a alienação faz falta In: Laznik-Penot, M.C. (Org). O que a clínica do autismo pode ensinar aos psicanalistas. 2. ed. Salvador: Àgalma, 1991. p. 31-48.

. Poderíamos pensar numa prevenção da síndrome autística? In: Wanderley, D.B. (Org). Palavras em torno do berço. Salvador: Àgalma, 1997. p. 35-51.

- Poderia a teoria lacaniana da pulsão fazer avançar a pesquisa sobre o autismo?. "Psicanálise e Clínica de bebês" da Associação Psicanalítica de Curitiba, Ano 4, n. 4, p. 76-90, dez. 2000.

LEBOVICI, S. O bebê, a mãe e o psicanalista. Porto Alegre: Artes Médicas, 1987. 307 p.

. As consultas psicoterapeuticas. In: Guedeney, A.; Lebovici, S. (Org). Intervenções psicoterápicas pais-bebês. Porto Alegre: Artmed, 1999. p. 63-71.

LEITE, N.V.A. Sema-soma In: Bernardino, L.M.F.;Rohenkohl, C.M.F. (Org). O bebê e a modernidade: abordagens teórico-clínicas. São Paulo: Casa do Psicólogo, 2002. p. 85-90.

LERUDE-FLÉCHET, M. Algumas observações sobre os sintomas das crianças In: Souza, A. M. (Org). Psicanálise de crianças. Porto Alegre: Artes Médicas, 1989. p. 38-46.

MACHADO, S. P. O atendimento psicológico pós-parto: uma ação preventiva In: $A$ escuta psicanalítica de bebês em maternidade. São Paulo: Casa do psicólogo, 1999. p. 62-79.

MANNONI, M. A criança sua doença e os outros. Rio de Janeiro: Jorge Zahar, 1971. $254 \mathrm{p}$.

. A teoria como Ficção. Rio de janeiro: Campus, 1982.121 p.

. A criança retardada e a mãe. São Paulo: Martins Fontes, 1985. 151 p. 
MATHELIN, C. Pratica analítica em neonatologia In: Wanderley, D.B. (Org). Palavras em torno do berço. Salvador: Àgalma, 1997. p. 129-142.

. Da pulsão de morte ao desejo de vida, ou as vicissitudes de uma terapia intensiva In: Wanderley, D.B. (Org). Agora eu era o rei: os entraves da prematuridade. Salvador: Àgalma, 1999. p. 61-79.

MAURY, M. Intervenções psicoterápicas nos bebês e seus pais no hospital. In: Guedeney, A.; Lebovici, S. (Org). Intervenções psicoterápicas pais-bebês. Porto Alegre: Artmed, 1999. p.1119-133.

MELMAN, CH. O Homem sem gravidade, Gozar a qualquer preço. Rio de Janeiro: Companhia de Freud, 2003. 211 p.

MILLER, J.A. Percurso de Lacan, uma introdução. Rio de Janeiro: Ed. Jorge Zahar, 1987. $151 \mathrm{p}$.

MOTTA, S.P.P. Prevenção em saúde mental - por que não? In: Bernardino, L.M.F.;Rohenkohl, C.M.F. (Org). O bebê e a modernidade: abordagens teóricoclínicas. São Paulo: Casa do Psicólogo, 2002. p.109-116.

. Ética e condição humana In: Melgaço, G.R. (Org.). A ética na atenção ao bebê. Psicanálise - Saúde - Educação. São Paulo: Casa do Psicólogo, 2006. p. 5160.

. Do prelúdio, da sonata e de outras cantatas na constituição do humano. In: Aragão, R.O. (Org). O bebê, o corpo e a linguagem. São Paulo: Casa do Psicólogo, 2004. p. 121-127.

PIONTELLI, A. Do feto a criança: Um estudo observacional e psicanalítico. Rio de Janeiro: Imago, 1995. 261 p.

PIZZOGLIO, Y.Q. Presença de um psicanalista em reanimação neonatal como auxiliar da vida psíquica. In: Guedeney, A.; Lebovici, S. (Org). Intervenções psicoterápicas pais-bebês. Porto Alegre: Artmed, 1999. p.111-117.

RABELLO, A. A função simbólica da UTI neonatal In: Aragão, R.O. (Org). O bebê, o corpo e a linguagem. São Paulo: Casa do Psicólogo, 2004. p. 177-189. 
SIKSOU, F.; GOLSE, B. Aspectos terapêuticos da observação direta. In: Guedeney, A.; Lebovici, S. (Org). Intervenções psicoterápicas pais-bebês. Porto Alegre: Artmed, 1999. p.49-55.

SIROL, F. Intervenções psicoterápicas em medicina fetal. In: Guedeney, A.; Lebovici, S. (Org). Intervenções psicoterápicas pais-bebês. Porto Alegre: Artmed, 1999. p.17-28.

SOLER, C. Hipótese Lacaniana. In: Percurso 29. Trad. Mania S. Dewik. Revisão Renato Mezan e Dominique Fingermann. São Paulo: Instituto Sedes Sapientiae, 2002. p. 5-14.

STORK, H.; LY, O.; MOTA, G. Os bebês falam. Como você os compreende. Uma comparação intercultural In: Busnel, M.C. (Org). A linguagem dos bebês. Sabemos escutá-los? São Paulo: escuta, 1997. p. 34-46.

SZEJER, M. A escuta Psicanalítica de Bebês em Maternidade. São Paulo: Ed. Casa do Psicólogo, 1999. 80 p.

TEPERMAN, D.W. Intervenção psicanalítica precoce: efeitos de suposição de sujeito. In: Bernardino, L.M.F.;Rohenkohl, C.M.F. O bebê e a modernidade: abordagens teórico-clínicas. São Paulo: Casa do Psicólogo, 2002. p.143-152.

Clínica psicanalítica com bebês, uma intervenção a tempo. São Paulo: Casa do Psicólogo, 2005. 159 p.

- Creche, psicanálise, prevenção In: Melgaço, G.R. (Org.). A ética na

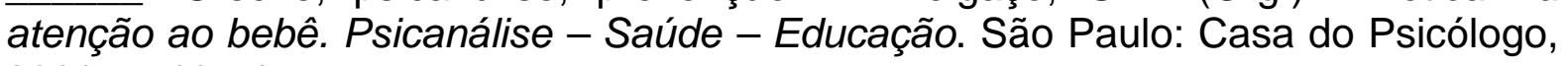
2006. p. 167-175.

VORCARO, A. Crianças na psicanálise: clínica, instituição, laço social. Rio de janeiro: Companhia de Freud, 1999. 206 p.

. Linguagem maternante e língua materna: sobre o funcionamento lingüístico que precede a fala In: Bernardino, L.M.F.;Rohenkohl, C.M.F. O bebê e a modernidade: abordagens teórico-clínicas. São Paulo: Casa do Psicólogo, 2002. p. 65-83. 
Os dragões do tempo primordial: A repetição como primeira identificação. In: Leite, V.A.L. (Org). Corpolinguagem: gestos e afetos. Campinas: Mercado de Letras, 2003. p. 215-132.

Sob a clínica: escritas do caso. Revista Literal da Escola de Psicanálise de Campinas, Campinas/São Paulo, n. 6, p. 11-36, 2003.

WANDERLEY, D.B. Palavras em torno do berço In: Wanderley, D.B.(Org). Palavras em torno do berço. Salvador: Àgalma, 1997. p. 143-162.

WEIL-HALPERN, F. Tornar-se mãe, graças aos progressos da medicina. In: Bernardino, L.M.F.;Rohenkohl, C.M.F.(Org). O bebê e a modernidade: abordagens teórico-clínicas. São Paulo: Casa do Psicólogo, 2002. p. 27-34.

WIRTH, A.F. Aplicação do método de observação de bebês em UTI neonatal. In: Caron, A.N. (Org). A relação pais-bebês, da observação à clinica. São Paulo: Casa do Psicólogo, 2000. p. 207-232.

ZEN,T.E.; NUNES, F.M. Intervenções precoces na gestação de alto risco: prevenção em saúde mental? In: Melgaço, G.R. (Org.). A ética na atenção ao bebê. Psicanálise - Saúde - Educação. São Paulo: Casa do psicólogo, 2006. p. 183-201.

ZORNIG, S.M.A.J.;MORSCH, D.S.; BRAGA,N.A. Parto prematuro: antecipação e descontinuidade temporal? In: Aragão, R.O. (Org). O bebê, o corpo e a linguagem. São Paulo: Casa do Psicólogo, 2004. p. 165-174.

- Clínica da intervenção precoce: entre a origem e o originário. In: Melgaço, G.R. (Org.). A ética na atenção ao bebê. Psicanálise - Saúde - Educação. São Paulo: Casa do psicólogo, 2006. p.73-78. 


\section{ANEXO \\ Termo de Consentimento Livre e Esclarecido}

Eu, Mariângela de Andrade Maximo Dias, psicóloga, registrada no CRP 06/31836, portadora do RG-3251243, doutoranda em Psicologia Clínica pela USP, declaro que a presente pesquisa tem como objetivo recolher, através da realização de entrevistas, a vivência dos pais dos bebês prematuros internados na unidade de tratamento intensivo neonatal do Hospital-Maternidade Celso Pierro. A pesquisa pretende verificar de que modo se constitui a relação entre pais e filhos durante o período de hospitalização dos bebês na referida unidade.

A pesquisa visa compreender a influência da rotina e dos dispositivos de cuidados da unidade de tratamento intensivo neonatal no relacionamento entre os pais e os bebês. Espera-se, com a análise dos depoimentos dessas vivências, analisar o modo como o acolhimento aos pais repercute no vínculo entre pais e filhos. Esta análise poderá contribuir para a organização de condutas que possam ser mais convenientes no estabelecimento dos laços afetivos entre pais e bebês. Será assegurado aos participantes da pesquisa o absoluto sigilo de sua identidade. As entrevistas serão realizadas em condições que garantam tanto o necessário acolhimento como privacidade dos entrevistados.

Saiba que a sua participação nesta pesquisa é totalmente livre para abandoná-la a qualquer momento sem nenhuma penalidade por isto. Além disso, você poderá solicitar que se retire dela qualquer contribuição que você já tenha eventualmente prestado. Os entrevistados poderão, a qualquer momento da realização da pesquisa, solicitar os esclarecimentos que julgarem necessários ao pesquisador quanto a qualquer aspecto que considerarem importantes. As entrevistas serão gravadas, caso haja autorização para tal procedimento.

Eu declaro ter sido informado e compreendido a natureza e objetivo da pesquisa e eu livremente consinto em participar. Declaro ainda ser maior de dezoito anos.

Nome:

Assinatura:

Data: 